\title{
Scientific researches
}

\section{for development future}

International Conference

March 28, 2020, New York, USA

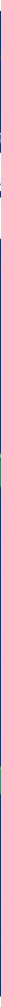


International Conference

SCIENTIFIC RESEARCHES

FOR DEVELOPMENT FUTURE

March 28, 2020, New York, USA

Conference Proceedings 


\section{B\&M Publishing}

Research and Publishing Center "Colloquium"

\section{International Conference}

\section{SCIENTIFIC RESEARCHES \\ FOR DEVELOPMENT FUTURE}

Science editor: R. Draut

Copyright (C) 2020

by Research and Publishing

Center "Colloquium"
ISBN 978-1-941655-00-9

DOI: http://doi.org/10.15350/F_7

All rights reserved.

Published by B\&M Publishing.

San Francisco, California 


\section{CONTENTS}

ECONOMICS, LAW AND PUBLIC ADMINISTRATION

On the definition of a quasi-thing category in Russian civil law 6 Pavlova Dariia

Aspects of gastronomic tourism in Kakheti 10

Tamarashvili Tamar

Mamulashvili Gela

Normative and legal documents for provision of competitiveness

of the society and persons in higher education institutions

Bannaev Nurmuhammad

Inflation: essence, types, causes

G. Shakirova

Compulsory licenses as a threat to patents in the pharmaceutical

biotechnology market

Gusarova Viktoria

Financial regulation of the rental housing market

Yessenbaikyzy Inkar

Methodological aspects of the export potential formation of Russia in the context of transformation of the external sector of the economy

Andreev Oleg

Kinds of innovation strategy and risks of innovative activity

A. Adashev

CULTURAL SCIENCE

Art therapy in space of modern culture abstract

Davtyan Vardan

The „The knight in the panther's skin,, and cultural paradigms of globalization 40 Nino Giorgadze

Isako Meparishvili

PHILOLOGY

Etymological classification of terminology

Damegul Seytova

Advertising discourse in linguistics

Umida Mahmudova

PEDAGOGY AND PSYCHOLOGY

Investigation of dynamics of primary school pupils' sense of language

Aghababyan Karine

Typology of social stereotypes

Zhumaev Ulugbel

The role of educational resources in $21^{\text {st }}$ century education

Fayzulina Umida

Khayrullaeva Sarvinoz

Ravshanova Gulkhayo

The urgency of the formation of a sense of homeland in the education

of preschool children

Abdurakhmonova Kamola 
Education reforms in the Republic of Uzbekistan: modern schools and modern education

Abrorjon Sadriddinov

Prospects for an integrative approach in the field of physical education teach- $\quad 68$ ing

Abytova Jasmine

Sattorova Parvina

Some issues of sports training planning

Arslonov Qahramon

O'roqova Saodat

Problems of optimization of activity of students in elementary classes by

means of physical means

Juraev Zhura

Muhiddinov Mirshod

Science and its role in modern society

Kamolova Sabrina

Methods for determining the degree of physical fitness

Yusupova Zulfizar

Rakhimova Laylo

Stress tolerance of teachers as the ability to prevent conflicts

Karimova Vasila

Mirzabdullaeva Dilxumor

Creativity as an individual's ability

Alieva Zulxumor

Features of the formation of the pedagogical image in the development

of the teacher's personality

Juraeva Sarvinoz

Methods of preparing children for school in fine activities

Abdullaeva Masuda

Abdullaev Dilmurod

Development of psychological features of attention at junior school-age

Abdullaeva Nilufar

Characterization of the process of education of patriotism

among students of higher educational institutions

Abdullaev Amrillo

Education of moral principles of preschool children

Gulbakhor Davronova

Nigina Ikramova

Important aspects of pedagogical skill and ways of its formation

Ochilova Manzura

Rakhimova Nilufar

MEDICAL SCIENCES

The problem of comorbidity in acute coronary syndrome without st segment 99 elevation

Grebenchikova Ekaterina

Cherepanova Ekaterina

Assessment of risk factors for chronic pancreatitis 
Features of diagnosis of chronic heart failure

Kurilyak Maria

Udina Elena

Assessment of adherence of patients with arterial hypertension

105

Kurilyak Maria

Udina Elena

Stenting as one of the modern methods of treatment of acute coronary syn- 107 drome

Storozheva Christina

Udina Elena

NATURAL SCIENCES AND TECHNICAL SCIENCES

Agromeliorative measures to improve and maintain soil fertility

109

Sattorova Maxfuza

Boltaev Muxlis

Development of the melon fly (myiopardalis pardalina big) in the conditions 112

of Karakalpakstan

E. Toreniyazov

R. Yusupov

Rearing two-year-old of different breeds of carp in cages conditions

of the republic of uzbekistan

B.B. Norboyev

A.O. Akramov

N. Adizova

D. Kholmirzayev

Fiberglass pipes from the unsaturated polyether on the basis of alcoholysis 117

products of secondary polyethylene terephthalate

A.B. Juraev

M.G. Alimuhamedov

F.A. Magrupov

Structure of bracts of some families of the genus acanthophyllum

E. Ruzmatov

D. Tuyzieva

B. Nizomova

O. Yuldasheva

Impact of anthropogenic factors on the diversity of tusheti protected areas 123

ecosystems

Tea Mchedluri

Lado Kakhoidze

Tinatin Khokhobashvili

Asmati Vepkhvadze

Determination of the content of heavy metals in particles of pollen of plants 129

causing pollinosis

Zuroshvili Lamara

Content of environmental education of students 


\section{ECONOMICS, LAW AND PUBLIC ADMINISTRATION}

\section{ON THE DEFINITION OF A QUASI-THING CATEGORY IN RUSSIAN CIVIL LAW}

\section{Pavlova Dariia ${ }^{1}$}

\section{Abstract}

This article is devoted to the consideration of the category of quasi-things in Russian civil law. The article shows the correlation of the category of quasi-things with other categories of property. Based on the analysis, distinctive features were identified and a conclusion was made about the uniqueness of this category in relation to other categories of property

Key words: quasi-things, property rights, things in civil law, property.

doi: http://doi.org/10.15350/F_7/1

Наравне с категориями объектов, предусмотренными Гражданским кодексом Российской Федерации, существуют иные категории, широко распространенные в отечественной и зарубежной доктрине. Среди непоименованных категорий имущества особое значение представляет категория «квази-вещей».

По мнению 3. И. Цибуленко, под квази-вещами следует понимать «вещи, признаваемые объективным правом в качестве объекта субъективных прав». C точки зрения И. А. Гумарова такими вещами являются имущественные права, законодательно наделенные свойствами вещи, а именно, способностью выступать в гражданском обороте как объект права собственности [1, с. 76].

Действительно, от традиционной категории «имущественных прав» квазивещи прежде всего отличаются наличием прямой дефиниции о распространении на такие объекты вещно-правового режима.

Такими объектами выступают документарные ценные бумаги и наличные денежные средства. Исходя из прямого толкования статьи 142 Гражданского кодекса Российской Федерации под документарными ценными бумагами дословно понимается «документ ... удостоверяющий обязательственные и иные права». Другими словами, обязательственные и иные права заключены в документарную (то есть материальную, овеществленную) форму, обладающую признаками, свойственными для традиционной категории вещей. Наличные деньги, в рамках статьи 30 Федерального закона от 10.07.2002 № 86-Ф3 «О Центральном банке Российской Федерации (Банке России)», заключают в себе безусловные обязательства Центрального банка России в виде нарицательной стоимости и выражаются в виде банкнот и монет. Таким образом, данные объекты представляют собой вещи в которых заключено право, действие которого определено прямым указанием закона.gusarova

По мнению А. Н. Лысенко «бестелесные вещи» (квази-вещи), как юридическое понятие представляет собой фикцию гражданского права [5]. Под фикцией в гражданском праве, по мнению 3. М. Черниловского, понимается «кажущийся акт,

\footnotetext{
${ }^{1}$ Pavlova Dariia, master of Jurisprudence, Saint-Petersburg state university of economics, Russia.
} 
с помощью которого достигается известный результат, одобренный данной системой права» [2]. М. Л. Давыдовой фикция рассматривается как прием юридической техники, который дает возможность правоприменителю строить правовую реальность [3]. К. К. Панько представляет под фикцией признание несуществующего существующим [6]. По нашему мнению, рассмотрение «бестелесных вещей», как правовой фикции допустимо, в виду того, что возможность признания объектов, входящих в данную группу таковыми, заключается, прежде всего, в признании таких объектов прямым указанием закона.

Д.В. Федотов [4, с. 96] выделяет следующие признаки, характерные для объектов, входящих в данную группу:

1. Нематериальность - отсутствие данного объекта в овеществленном выражении;

2. Дискретность - обособленность объекта от других объектов гражданских прав (внешняя дискретность), с учетом возможности выделения конкретной единицы (внутренняя дискретность).

3. Ценность - обладание определенным стоимостным выражением, как участника товарных отношений.

Важно отметить, что именно благо выражает нематериальность данных объектов, но оставляет возможность выразить себя в материальном мире через определенный носитель (например, бумажный или металлический эквивалент), с помощью которого и допустимо применить к таким объектам вещно-правовое регулирование, в части появления возможности служить объектом реального товарообмена, распространения на квази-вещи права собственности и иных особенностей, свойственных вещам. Логичным представляется сравнить категорию квазивещей с традиционной вещной категорией:

Таблица 1

Сравнение категории вещей, квази-вещей и имущественных прав

\begin{tabular}{|c|c|c|c|}
\hline Критерий & Вещи & Квази-вещи & $\begin{array}{c}\text { Имущественные } \\
\text { права }\end{array}$ \\
\hline Форма выражения & Материальная & $\begin{array}{c}\text { Опосредованно-ма- } \\
\text { териальная }\end{array}$ & Нематериальная \\
\hline $\begin{array}{c}\text { Полезность для } \\
\text { участников граж- } \\
\text { данско-правовых } \\
\text { отношений }\end{array}$ & $\begin{array}{c}\text { Благо (в том числе } \\
\text { экономическая цен- } \\
\text { ность) }\end{array}$ & $\begin{array}{c}\text { Благо (в том числе } \\
\text { экономическая цен- } \\
\text { ность) }\end{array}$ & $\begin{array}{c}\text { Благо (в том } \\
\text { числе экономиче- } \\
\text { ская ценность) }\end{array}$ \\
\hline $\begin{array}{c}\text { Способность удо- } \\
\text { влетворять по- } \\
\text { требности субъек- } \\
\text { тов гражданских } \\
\text { правоотношений }\end{array}$ & Возможно & Возможно & Возможно \\
\hline $\begin{array}{c}\text { Способность вы- } \\
\text { ступать предме- } \\
\text { том товарообмена }\end{array}$ & Возможно & Возможно & Возможно \\
\hline $\begin{array}{c}\text { Способы защиты } \\
\text { нарушенного } \\
\text { права }\end{array}$ & $\begin{array}{c}\text { Традиционные } \\
\text { гражданско-право- } \\
\text { вые способы за- } \\
\text { щиты, включая вин- } \\
\text { дикацию и негатор- } \\
\text { ный иск } \\
\end{array}$ & $\begin{array}{c}\text { Традиционные граж- } \\
\text { данско-правовые } \\
\text { способы защиты, } \\
\text { включая виндика- } \\
\text { цию и негаторный } \\
\text { иск } \\
\end{array}$ & $\begin{array}{c}\text { Традиционные } \\
\text { гражданско-пра- } \\
\text { вовые способы за- } \\
\text { щиты, включая } \\
\text { негаторный иск }\end{array}$ \\
\hline
\end{tabular}

На основании данных, приведенных в Таблице 1 , представляется логичным выделение квази-вещей из имущественных прав и отнесение именно к категории 
«вещей». От иных имущественных прав квази-вещи отличаются прежде всего способностью выражения через объект материального мира, способный существовать опосредованно (внешняя и внутренняя дискретность) и возможность применения к квази-вещам традиционные способы защиты (включая вендикационные иски).

По нашему мнению, для более детального понимания правовой природы бестелесных вещей (квази-вещей), также целесообразно выделить признаки, свойственные имуществу как главенствующей категории (родовые признаки) и признаки, свойственные исключительно бестелесным вещам (видовые признаки):

Родовые признаки:

1. Способность объекта иметь определенную экономическую стоимость, подлежащую оценке в товарно-денежных отношениях.

2. По общему правилу способность объекта принадлежать, отчуждаться и переходить от одного лица к другому.

3. Способность объекта служить средством реализации имущественного интереса.

4. Обособленность объекта от других объектов гражданских прав (внешняя дискретность), с учетом возможности выделения конкретной единицы (внутренняя дискретность).

Видовые признаки:

1. Нематериальная природа (невозможность выступать объектом материального мира).

2. Ценность, заключенная в данном объекте, исходит не из его физических свойств, а в силу наделения такой ценностью антропогенным фактором.

3. Возможность придания нематериальному благу физическое выражение с использованием вспомогательных материальных элементов.

Таким образом, бестелесное имущество по своим признакам совпадает с традиционной категорией «телесного имущества», в части способности принадлежать субъектам гражданских прав на основании закона или договора, отчуждаться и переходить от одного лица к другому, а также способностью субъекта защищать свои права на бестелесное имущество предусмотренными законом способами, свойственных вещам. Существенным отличием бестелесного имущества является его нематериальность и специфическая ценность.

Квази-вещами признаются имущественные права способные с учетом своей специфики с помощью правовых конструкций опосредованно выражаться в качестве объектов материального мира. Другими словами, квази-вещи представляют собой совокупность вещей и имущественных прав.

Такими объектами, к которым законодательно применена квази-вещная конструкция, признаются документарные ценные бумаги и наличные денежные средства. Данное обстоятельство прежде всего связано с возможностью применения указанной конструкции и обусловленной необходимостью правового регулирования указанных объектов с учетом заинтересованности субъектов, взаимодействующих с ними.

\section{References}

[1] Понятие вещи в современном гражданском праве России / Гумаров И.А. // Хозяйство и право. 2000. № 3. - С.78-84.

[2] Презумпции и фикции в истории права / Черниловский 3.М. // Советское государство и право. 1984. № 1. - 104 с.

[3] Проблемы понятия и классификации правовых фикций / Давыдова М.Л. // Вестник ВолГУ. 2009. № 11. - 98 с. 
[4] Бестелесное имущество в гражданском праве : диссертация ... кандидата юридических наук : 12.00.03 / Федотов Дмитрий Витальевич; [Место защиты: Ур. гос. юрид. акад.]. Екатеринбург, 2012. - 214 с.

[5] Понятие и виды имущества в гражданском праве России : диссертация ... кандидата юридических наук : 12.00 .03 / Лысенко Александр Николаевич; [Место защиты: Кубан. гос. аграр. ун-т]. - Самара, 2007. - 233 с.

[6] Фикции в уголовном праве: в сфере законотворчества и правоприменении: диссертация ... кандидата юридических наук : 12.00 .08 / Панько Кирилл Константинович. - Ярославль, 1998. - 233 c. 


\section{ASPECTS OF GASTRONOMIC TOURISM IN KAKHETI}

\section{Tamarashvili Tamar ${ }^{1}$}

Mamulashvili Gela ${ }^{2}$

\section{Abstract}

The research paper is about gastronomic tourism, which is considered to be one of the most popular fields of tourism. The food is analysed as a characteristic of national identity and cultural heritage. The article also examines the aspects and resources of gastronomy in the region of Kakheti.

Key words: Georgia, gastronomical tourism, Kakheti, hospitality, perspectives.

doi: http://doi.org/10.15350/F_7/3

Каждые страна и народ имеют своеобразия традиционного питания, его исторический опыт, пища является показателем национальности и характера культурного наследия, а также и показателем ментальности. Нужно отметить, что устойчивость ко времени и пространству, кроме пищи не является характерным ни для одного другого элемента материальной культуры.

Система грузинского питаниясо структурной точки зрения, весьма многообразна, её значение определяется: чисто биологическим, нутриционистическим и социально-религиозными аспектами. В виду того, что Грузия - страна с весьма старой культурой, традиционно грузинские блюда выделяются богатой и многообразной экзотикой, а грузинское застолье именуют «академией», т.к. решение многих важнейших вопросов осуществлялось именно во время трапезы. Патриарх всея Грузии Илья II говорит: «Христианский приём пищи является местом единства и поддержки людей в горе и радости, это место, где царствует Господь. Поэтому трапеза начинается и заканчивается молитвой. Грузинское застолье уникальный инструмент христианской любви и взаимоуважения.» [6]

Приезжающих в Грузию визитёров, приводят в восторг не только грузинские блюда, но и институт «тамады», последовательность и традиции особенных, ритуальных тостов. Нужно отметить то обстоятельство, что по приказу генерального директора национального агентства защиты культурного наследия, традиционному грузинскому застолью присвоен статус нематериального культурного наследия.

Содержание: «Туризм - эффективный способ развития и познания своих и чужих ценностей. Такое направление туризма, как гастрономический туризм, является одним из лучших средств сближения людей разных национальностей и интеркультурной коммуникации. Гастротурист пробует пищу и напитки не только в местах массового питания, он старается отведать и локально-аутентичную, местную пищу. Во время гастротура визитёр пробует блюда, приготовленные из мяса, молока, морских продуктов, к тому же он расширяет свои знания по поводу данной страны и народа.

\footnotetext{
${ }_{1}^{1}$ Tamarashvili Tamar, Associate Professor, Iakob Gogebashvili Telavi State University, Georgia.

${ }^{2}$ Mamulashvili Gela, student, International University of the Black Sea, Georgia.
} 
Каждая страна характерна своими, только лишь ей присущими особенностями питания и гостеприимства, что вызвано историей данной страны, её географическим положением, культурой, народными традициями и религиозным вероисповеданием. «Грузинская гастрономическая культура, как и народная музыка страны, является полифоничной, что хорошо отображается и на её кулинарии. Как каждый звук имеет своё предназначение, так и каждые компоненты, входящие в то или иное блюдо, в совокупности создают тот неповторимый букет, который именуется грузинским вкусом», - говорит исследователь гастрономической культуры, Дали Цатава, которая «полифоничность» грузинского вкуса видит как в блюдах, также и в таком дифференцированном ритуале, каким является грузинское «застолье».

Сегодня, в эпоху глобализации, гастротуризм во всём мире весьма популярен и имеет довольно большой спрос, множество визитёров путешествует по всему миру гастротурами. Велик интерес иностранцев к грузинским блюдам. «Грузия страна кулинарной культуры и множество визитёров интересуется традиционными грузинскими блюдами, которые могут занять ведущее место среди китайской, итальянской и французской кухни. В том случае, если гастрономический тур будет запланирован должным образом, всё станет более привлекательным для туристов Грузии» [10].

Туристы, приехавшие в разные регионы и деревни Грузии, хотят пробовать не только разные национальные блюда, но и знакомятся с их рецептами и стараются изучить технологию их приготовления, чтобы вернувшись на свою родину поделиться с друзьями и близкими секретами грузинской кухни. Кавказская кухня выделяется мозаикой своих цветов, а Грузия также является её неотъемлемой частью. «... национальная кухня самобытна, оригинальна, аутентична, приготовление определённых блюд связано с определёнными правилами, не надо забывать также, что кухня часть нематериальной культуры. Гастротуризм работает в течении всего года и не характерен сезонностью. При исследовании мировой туристической организации гастрономия и кулинарная практика признана отдельной областью» [1].

При моделировании гастротуров туроператоры должны уделять особое внимание пище, делать акцент на фольклор, песни и танцы, которые являются особенным украшением грузинского застолья. Знакомство с вышеперечисленными фактами, приводит в восхищение иностранных визитёров. «Любой этнос предлагает туристам знакомство с теми особенными этнокультурными ценностями, которые ещё сохранились в сёлах и отдельных регионах, несмотря на процессы быстрой глобализации, которая нарушает самобытность» [5].

На сегодняшний день для развития гастротуризма в Грузии осуществляется множество проектов. Важным является активное сотрудничество между ассоциацией гастрономии Грузии и национальной администрацией туризма. Их цель - популяризация нематериального культурного ресурса национального значения и развитие внутреннего туризма в Грузии. Гастрономическая культура может стать ресурсом для имиджа региона. Нужно способствовать созданию гастрономических маршрутов региональной кухни страны и сбору данных, чтобы все регионы получили пользу от гастрономического туризма, а благодаря хорошо запланированному и предоставленному гастрономическому туру повысится и жизненный уровень населения того или иного региона.

Желательно создать региональные гастрономические маршруты. Для этого нужно собрать данные старинных рецептов, ритуалов и традиций, которые будут касаться кухни того или иного региона. Нужно подробно расписать туристические 
маршруты, таким образом все регионы получат выгоду на основании гастрономического богатства своего региона. Хорошо запланированным и рекламированным туром повысится и знание о данном регионе, о доходе населения, повысится знание о нематериальном наследии и культурных ценностях, в то же время будут сохранены традиционные ценности и самобытность конкретного региона.

Успешными внутренними турами будет уравновешен несезонный период. Гастрономические туры на рынке туризма Грузии будут новым продуктом, что поможет населению Грузии узнать: региональную материальную и нематериальную культуру своей страны, социальный быт и этапы его развития до сегодняшнего периода.

Глобализация вызвало уничтожение многих традиций, хотя то, когда-то утерянное из нашей ежедневной жизни, можно оживить, и это станет весьма интересным для туристической активности. Нужно предусмотреть и то обстоятельство, что-то или иное блюдо является началом новой интерпретации истории, мифов и традиций. Грузинское застолье, законы гостеприимства - особенный феномен во всём мире, который никого не оставляет равнодушным! Известные всем хинкали, шашлык, хачапури, любимые для всех чурчхелы и т.д. - всё это неотъемлемая часть грузинского застолья и представляют собой уникальное соединение грузинской кулинарии и традиций. Думаю, что гастрономическому туру в регионах особую изюминку придаёт посещение и включение в маршрут предприятий имеющих знак «грузинского качества». Предприятие «Сыр Циви» («Цивис квели») - единственное предприятие, в котором производят 70 разновидностей 11 видов сыра (сулгуни, творог, надуги, масло и т.д.). Здесь можно попробовать «сыр, окунутый в мёде, выдержанный в чаче, и состаренный в вине...». Продукция пользуется большим уважением и спросом, продаётся не только в Грузии, но и вывозится за границу. Компания производит свою продукцию, лишь из натурального молока. Туристы имеют возможность осмотреть завод, продегустировать сыр и принять участие в его изготовлении.

На грузинском туристическом рынке это новый туристический продукт. Предприятие работает как на коровьем молоке,так и на буйволином. Исходя из этого, визитёрам предлагается сыл и сулгуни, обладающие особенными вкусовыми качествами. Визитёрам вместе с дегустацией сыров особенно нравится включение и участие в непосредственный процесс производства сыра. Здесь осуществляется сохранение старых, давно почти забытых традиций производства сыра и их передача новому поколению, что отвечает требованиям развития туризма. Иначе говоря - производимая продукция должна быть не только вкусной, но и полезной и безопасной для здоровья.

На пути развития гастротуризма в Кахетии, думаю, весьма важную роль выполняют, существующие в регионе биопредприятия. В них создаётся чистая продукция и с экологической и с санитарной точек зрения, это очень важный аспект для любителей гастротуризма.

Очень интересным может быть и инновационное биодинамическое хозяйство в с. Руиспири, Телавского района. В условиях глобализации с каждым днём становится более востребованным экологически чистый продукт. С этой стороны данное предприятие очень интересно, оно пользуется большим одобрением как в самой стране, так и на международном рынке. В биодинамике большое значение присваивается циклам луны и астрологическим характеристикам, солнцу и луне, небесным телам. Из опыта ясно, что они сильно влияют на рост живых организмов. Перед современным миром остро стоит вызов - предоставить населению экологически чистый и здоровый продукт, и в то же время защитить природу от внешних 
рисков. Биодинамика перед нами предстаёт как оригинальное хозяйство, её предпочтенье многообразно. Данное хозяйство существует с 2014 года и принадлежит Г. Аладашвили. Процесс обработки почвы и виноградника биодинамическим методом он изучил в Шейцарии, а на виноградниках в д. Руиспири на земле своих предков, он собрал старые сорта грузинского винограда.

Бизнесмен обостряет внимание на здоровый продукт, что прямо связано с проблемой современности, состоящей в обеспечении производства экологически чистых продуктов. Хозяйство интересно также и тем, что виноградник обрабатывается по лунному календарю, лошадьми и вручную, а полученный урожай настаивается по грузинским обычаям - в квеври. Вместе с вином экспортируются также и чурчхела, мёд, сухофрукты и варенья. На территории данного хозяйства есть пространство, где проводятся такие мастер-классы как: сбор винограда, приготовление шашлыка, дегустация вина и т.д. В состав меню только лишь биологически чистые продукты, которые изготовлены на месте. Биодинамическое хозяйство как с точки зрения гастротуризма, так и со стороны образования новых рабочих мест, имеет высокий потенциал. Кроме того деятельность бизнесмена служит национальным интересам, что заключается в сохранении традиционной технологии винного производства и восстановлении старинных грузинских сортов винограда. Здесь также предлагают гурманам хлеб, испечённый из старинного сорта пшеницы, выращенной также методами наших предков, хлеб характерен лучшими вкусовыми качествами и ароматом.

Нужно отметить, что с гастротуристической точки зрения национальные меньшинства и представители других религиозных конфессий предлагают визитёрам оригинальную и вкуснейшую кулинарную продукцию. В частности, во время туристического маршрута по Панкисскому ущелью, визитёры могут попробовать кистинскую кухню. Представители прекрасного пола Панкисского ущелья стали победительницами шоу «Законы моей кухни» на телеканале «Рустави 2». Они приготовили и предложили жюри«джиджиг галнаш» (копчёное мясо и варёное тесто с чесночным соусом) и «калдеелт гал», т.е. варёные кукурузные лепёшки и творог в топлёном сливочном масле с зелёным соусом, «аджапсандал» и овечьи рёбрышки, чеченскую халву с малиновым соусом.Панкисские женщины заслужили высшую оценку, ими были приготовлены и «гаабакх хингалиш» - тот же хачапури, но с тыквенной начинкой, а основным блюдом они представили «маамтиш» - варёный на пару фарш в тесте, который нужно заправить соусом из помидор, лука и болгарского перца.

\section{Выводы:}

1.На Кавказе, а в частности в Грузии, есть мощная ресурсная база, особое гостеприимство населения, гастрономиченские шедевры, большие отличия между отдельными регионами. Само многообразие среди регионов в сфере народных празднеств, ремёсла, богатейшие традиции своеобразной кухни, в совокупности всё создаёт весьма благоприятные условии для создания и развития гастротуризма. Нужно создать единую базу данных, чтобы гастротурист имел возможность посетить тот или иной регион для того, чтобы попробовать интересное для него блюдо.

2.В регионах Грузии, а в частности в Кахетии, гастротуры вызовут активное подключение всего населения, в результате всё это вызовет развитие туризма. Повысится знание городов и регионов. Важную роль сыграет создание отдельных видеороликов, рекламы и пиар. «Необходимо подготовить гидов и туроператоров, которые создадут оригинальные туристические пакеты» [3].

3.Для популяризации гастротуров определённую роль могут сыграть и города-побратимы, кроме того можно использовать и опыт других стран, пригласить 
известного шеф-повара, устраивать мастер-классы, особенно для городских праздников. Гурманов привлекают фестивал чачи, вина, пива, мёда, сыра, которые довольно часто проводятся в Кахетии.

4.Нужно отметить и то обстоятельство, что Грузия с точки зрения гастротуризма попала в список сучших стран, а хачапури и чурчхела в списке топ-десятка уличной едыForbes-a. При помощи интернет-опроса был составлен рейтинг лучших городов и стран на тему летнего гастрономического тура, куда лучше поехать для изучения местной гастрономии [9].

5.Для развития и популяризации маштабов гастротуризма в Кахетии важное значение придаётся использованию академического знания, соответствующее образование, конечно же велико, но важным является знание искусства его показа. С этой точки зрения необходимо изучение разных кулинарных искусств мира. В настоящее время между Телавским государственном университетом им. Я. Гогебашвили и Лионским университетом им. Пауло Бокуса существуют и осуществляются специальныее программы по обмену студентами, это даёт студентам, имеющим специальности по туризму, хорошую возможность освоить создание оригинальных гастрономических туров, как на внутреннем, так и на внешнем рынке. Молодёжь в пределах программы-обмена знакомятся с тайнами кулинарного искусства, а полученнай при этом опыт, поможет им при успешном осуществлении гастрономических туров.

Сегодня в Грузии хорошо функционирует организация гастрономического туризма, целью создания которого является популяризация грузинской кулинарии и работа над теми проблемами, которые существуют в Грузии в данной сфере. В данной организации объединяются гастрономические компании, заинтересованные лица, цель ассоциации состоит втом, чтобы ознакомить весь мир с грузинской кулинарией и установить тесное сотрудничество с гастрономическими ассоциациями, принимать участие на международных конкурсах, заботиться о развитии юридических и физических лиц, занятых в данной сфере, устраивать форумы и тренинги высшего уровня, как в больших городах Грузии, так и в её регионах.

\section{References}

[1] Гвинджилия М., Поискиучёных ускусства, 1(74), 2018, Тбилиси;

[2] Тбилисский государственный университет театра и кино им. Ш. Руставели, Тбилиси;

[3] Научный журнал «Право и экономика», 20018г. № 9, Грузя, Тбилиси;

[4] Научный журнал «Новация», 2008 г. №3;

[5] Материалы международной конференции, Батуми, 2009 г.;

[6] Топчишвили Р. «Этнология-этнография Грузии», 2010 г., Тбилиси;

[7] Хачапуридзе Р. Харатишвили Л. «Учебник для семейных гостиниц, своеобразия ритания туристов», 2010 г., Тбилиси.

[8] http://www.xn--lodilbhkklj3a2a.xn--node/index.php/okgastro/17411?fbclid=IwAR1JK1JxxBFWPPZlkLNWifObMUQJDtS0z6s0WNXd2vtr9CvOPGEnabL tUl8

[9] https://sputnik-georgia.com/tourism/20190619/245635106/saqarTvelo-ruseTSi-CatarebuligamokiTxviT-saukeTeso-gastronomiuli-qveynebis-siaSia.html

[10]Учебник для семейных гостиниц. «Особенности питания туристов», Тбилиси, 2010, Е. Хачапуридзе, Л. Харатишвили, стр. 3. 


\title{
NORMATIVE AND LEGAL DOCUMENTS FOR PROVISION OF COMPETITIVENESS OF THE SOCIETY AND PERSONS IN HIGHER EDUCATION INSTITUTIONS
}

\author{
Bannaev Nurmuhammad ${ }^{1}$
}

\section{Abstract}

This article analyzes the legal acts that guarantee the interaction of society and people in higher education.

Key words: normative legal acts, convention, law, education, society, person, reciprocity.

doi: http://doi.org/10.15350/F_7/4

\section{Introduction}

From the very first days of independence the state and government have paid a lot of attention to improving the living conditions of our people, social protection and legal literacy of the population, increasing the legal culture of the society. During this period, a number of measures have been developed and put into practice. The Constitution of the Republic of Uzbekistan and the codes and laws, which are based on it, along with protection of the rights and freedoms of the people, prioritize human interests and ensure decent living of the population. The words of our President Shavkat Mirziyoev at the solemn event, dedicated to the 26th anniversary of the adoption of the Constitution of the Republic of Uzbekistan, can be proof of our opinion."We must not forget that the ultimate goal of any legislative act is to improve the living conditions of our people. The main issue in this process is the timely delivery of the essence of the legislation to the executors and the population, and strict enforcement of their implementation," the President said in his speech.

\section{Main part}

Normative-legal acts are subdivided into types of laws and by-laws, which are:

- The Constitution of the Republic of Uzbekistan;

- Laws of the Republic of Uzbekistan;- decisions of Chambers of the Oliy Majlis of the Republic of Uzbekistan;

- decrees, resolutions and orders of the President of the Republic of Uzbekistan;

- resolutions of the Cabinet of Ministers of the Republic of Uzbekistan;- Orders and decisions of ministries, state committees and agencies;

- Decisions of local authorities.

As the Republic of Uzbekistan strives for building a democratic legal state and civil society, one of its main tasks is to develop a fully developed and free individual. One of the key tools for implementing and pursuing a targeted state policy in the field of education. In the higher educational institutions, the Constitution of the Republic of Uzbekistan occupies a special place among the normative and legal acts ensuring harmony of public and private interests. Our Constitution guarantees the right to education based on the norms of international law.The main components of the National Model of Personnel Training are the individual, the state and society, continuous education, science and production.In this model, the person is the main subject and object of the system of

\footnotetext{
${ }^{1}$ Bannaev Nurmuhammad, Senior Lecturer, Department of "National Ideas, Fundamentals of Spirituality and Law Education", Namangan State University, Uzbekistan.
} 
personnel training, which, through education in the system of continuous education, will be able to contribute to the prosperity of the Motherland through the development of harmonious, high spirituality, professionalism and knowledge; and commitment to the principles of independence through respect for national and universal values that promote social co-operation with its international community.The state and society along with improving the material and technical base needed for implementing and implementing state and social orders to the system of continuous education, regulating and controlling the activities of the system of training, attestation and accreditation, training of personnel and the need for employment. Provides support.To date, the annual expenditure on the development and reforming of education in the country amounts to $10-12 \%$ of GDP. The share of the system in the State budget is more than $35 \%$.The normative legal acts of the President of the Republic of Uzbekistan on the development of higher education, including the priorities for the development of each type of education, were adopted. To this end, the Decree of the President of the Republic of Uzbekistan "On Approval of the Concept of Development of Higher Education of the Republic of Uzbekistan until 2030, dated October 8, 2019, PF-54847 serves as a normative document ensuring harmony of public and private interests in higher education institutions. The shortcomings areCurrently, there are 114 higher education institutions in the country, of which 93 are local and 21 are foreign higher education institutions and their branches.In the 2019/2020 academic year, 59 forms of correspondence education were introduced in 59 higher educational institutions and evening education in 10 higher educational institutions. Admission parameters for the 2019/2020 academic year were 121,000 and increased by $18 \%$ compared to the previous year, and by $92 \%$ compared to 2016 . Staff at 16 higher educational institutions of the Republic of Uzbekistan on the basis of joint educational programs with foreign higher education institutions from 2018/2019 academic year. preparation activities are organized.

\section{Conclusion}

I believe that the goal of today is to improve the quality of education and training of competitive personnel in the field of higher education. It is important to note the following:- development of recommendations for improving the quality of education, improvement of curricula and introduction of modern pedagogical technologies;establishing effective public control over the provision of high quality education in the system of financial education.

\section{References}

[1] Mirziyoev Sh.M. Speech at the solemn ceremony dedicated to the 26th anniversary of the adoption of the Constitution of the Republic of Uzbekistan "Educated generation is a great future, entrepreneurial people is a guarantee of a prosperous life, friendly cooperation is the source".

[2] Source: lex.uz. Law on normative legal acts December 14, 2000

[3] Constitution of the Republic of Uzbekistan. 2019. Article 41 B-

[4] Source: uza.uz December 23, 20155. Lex.uz. 


\section{INFLATION: ESSENCE, TYPES, CAUSES}

\section{G. Shakirova ${ }^{1}$}

Abstract

In this article we consider the disclosure of the meaning of the inflation process, by examining the concept of inflation, its causes and types.

Key words: Inflation, economy, main economy, radical economy, vulgar economy, Chicago school.

doi: http://doi.org/10.15350/F_7/5

Qualitative changes in the modern economy are demonstrated by the fact that there has been a significant regrouping of factors and sources that determine economic development. The decreasing opportunities of traditional resources for economic growth are related both to the approaching of the physical limits of their use, and to the decreasing efficiency and increase in the costs of environmental protection measures. This means that a system of innovative processes, scientific knowledge, new technologies, products and services should become the dominant in the development of the model of economic growth in the XXI century.

Inflation is the depreciation of money, a reduction in their purchasing power, an imbalance in supply and demand. In a literal translation, the term «inflation» (from the Latin inflatio) means «swelling», i. E. the overflow of channels of circulation with excess paper money that is not secured by the corresponding growth of the commodity mass, which causes the depreciation of the monetary unit and, consequently, the growth of commodity prices.

The term «inflation» appeared in the second half of the XIX century, moving from medicine. It first began to be used in North America during the civil war of 1861-1865. and denoted the process of swelling of paper-money circulation. In the XIX century. This term was also used in England and France. The notion of inflation was widely spread in the economic literature in the twentieth century. after the First World War. «In essence, this term was money inflation,» writes V. Drozdov. «But in the future under inflation ... any increase in prices began to be understood, regardless of the causes that generate it.»

However, the definition of inflation as an overflow of channels of monetary circulation by depreciating paper money can not be considered complete. Inflation, although it manifests itself in the growth of commodity prices, can not be reduced only to a purely monetary phenomenon. This is a complex socio-economic phenomenon caused by imbalances in reproduction in various spheres of market economy. Inflation is one of the most acute problems of modern economic development in many countries of the world.

For a more objective view of inflation, one should consider the various inflation theories that exist today.

The history of the economy includes a rather large number of different economic doctrines, schools and trends: classics and neoclassicists, mercantilists, physiocrats, Marxist economy, institutional, and mainstream economics, radical economy, vulgar

\footnotetext{
${ }^{1}$ G. Shakirova, Teachers of the Department of Management, Namangan Engineering Construction Institute, Namangan, Uzbekistan.
} 
economy, Chicago school and liberalism, the Elbreite trend and many others. Representatives of almost each of these areas have developed or are developing their views on the global economic problems of mankind. There are also their theories concerning inflation as one of the most serious problems hindering full-fledged economic development.

In the traditional Marxist economy, inflation was understood as a violation in the process of social production in pre-capitalist formations and under conditions of capitalism, which manifested itself in overflowing the sphere of circulation with money signs in excess of the real needs of the economy and their depreciation. Inflation, according to the Marxist school, is organically linked to the features of the reproductive cycle, state-monopoly regulation of economic processes, militarization of the economy, unemployment, etc. It is generated by the socio-economic contradictions of capitalist production, the disproportion between the real volume of the social product and its value expression. And it is used by the ruling exploiting classes to redistribute the national income and national wealth to their own advantage by reducing the real incomes of the working people. To its immediate causes, the Marxist school attributed objectively the changes in the volume and structure of social production, the policy of the monopolies and the imperialist states, the main one of which was the budget deficit.

English economist A. Phillips in 1958, using the data of UK statistics for the years 1861-1956, proposed a curve reflecting the inverse relationship between the level of wage rates and the unemployment rate. It was found that an increase in unemployment in England of more than 2.5 - 3\% led to a sharp slowdown in price and wage growth. Hence the conclusion that the decrease is accompanied by an increase in prices and wages. Thus, the unemployment rate can be reduced by accelerating the rate of inflation.

The economist R. Lipsi summed up the theoretical basis for the calculations of Phillips. Later, American economists P. Samuelson and R. Solow modified the Philips curve, replacing the wage rates with the growth rates of commodity prices. In this form, the curve began to be used for economic policy, primarily to determine the levels at which a high level of employment and production and a certain stability of prices are possible.

The abscissa shows the unemployment rate, on the y-axis - the growth rate of commodity prices. If the government considers the unemployment rate $\mathrm{u} 1$ to be excessively high, then budgetary and monetary measures stimulating demand are conducted to reduce it, which leads to expansion of production and creation of new jobs. The unemployment rate is reduced to, but the rate of inflation to P2 is simultaneously increasing. The resulting conditions can cause crisis phenomena, which will force the government to take measures to reduce the rate of price growth to the level of P3, and unemployment will increase to the level of $\mathrm{u} 3$.

In practice, it turned out that the Phillips curve is applicable to the economic situation in the short term, because in the long term, despite high unemployment, inflation continues to increase, which is explained by a whole set of circumstances.

One of such circumstances is the policy of stimulating demand. The government's desire to reduce the unemployment rate at the cost of increasing inflation is successful only if the population succeeds in creating so-called «false expectations.» For example, working for hire, watching the growth of wage rates, increase labor supply. And then, as expected in the concept of the Phillips curve, there is an increase in inflation and associated nominal wages. However, as soon as people start to notice that the real wage, unlike the nominal one, decreases all the time, the increase in the supply of labor stops.

Keynesians view the money supply as an endogenous variable, which depends on the policy of the monetary authorities and the level of economic activity. "Inflation of costs» is interpreted as the result of several factors. The main one is considered to be an 
increase in wages above the level corresponding to the growth of labor productivity. Although, according to Keynes, «full or ... approximately full employment is a rare and quickpassing event.»

The level of employment is determined by Keynes by the point of intersection of the functions of aggregate demand and aggregate supply. It is at this point that the expected profit by entrepreneurs will be the greatest. In advocating the conscious management of monetary circulation, Keynes considered it necessary to use various kinds of measures only with part-time employment. He warned against using monetary leverage in conditions of full employment, believing that in this case they could cause unrestrained inflation.

\section{References}

[1] Management of the organization / Ed. AGPorshneva, Z.P. Rumyantseva, N.A. Salomatin. - Moscow: Infra - M, 1999.

[2] Fundamentals of commercialization of the results of NPOKR and technology / Comp. N.M. Fresheret. $\mathrm{M}$.: ANH, 1999.

[3] Шакирова, Г. Ш., \& Узбекистан, Н. (2016). ПОДДЕРЖКА МАЛОГО БИЗНЕСА И ЧАСТНОГО ПРЕДПРИНИМАТЕЛЬСТВА-ВАЖНЫЙ ФАКТОР СТАБИЛЬНОСТИ ЭКОНОМИЧЕСКОГО РАЗВИТИЯ. Теория и практика современной науки, (4), 806-808.

[4] Шакирова, Г. Ш. (2017). МИЛЛИЙ ИҚТИСОДИЁТ ТАРАҚҚИЁТИДА ХОРИЖИЙ ИНВЕСТИЦИЯЛАРНИНГ ЎРНИ. Научное знание современности, (4), 405-407.

[5] Mamajonova, G. K. (2019). The role of bioethics in fostering the family's spiritual foundations. International Journal of Advanced Science and Technology, 28(12), 397-401.

[6] Mamazhonova, G. K. (2019). ROLE OF BIOETHICS IN THE DEVELOPMENT OF MEDICINE AS A CULTURAL FORM. Scientific Bulletin of Namangan State University, 1(7), 164-169.

[7] Mamajonova, G. K. (2019). Bioethics-Institutional Mechanism of Social Control of Criteria for Ethical Choice and Ethical Responsibility. Journal of Sources of Science, (5), 30-33.

[8] Shakirova, G. S., \& Mirzaabdulayeva, G. M. (2019). The relationship between the development of science, technology and innovation. ACADEMICIA: An International Multidisciplinary Research Journal, 9(3), 27-33. 


\section{COMPULSORY LICENSES AS A THREAT TO PATENTS IN THE PHARMACEUTICAL BIO- TECHNOLOGY MARKET}

\section{Gusarova Viktoria 1}

\section{Abstract}

This article is devoted to the issues of initiating the issuance of compulsory licenses for pharmaceutical biotechnologies by the state. This entails an unavoidable violation of the patent owner's rights, because such a license circumvents the patent. Therefore, the reasons for issuing such licenses must be very significant. The author of this article examines the mechanism of compulsory licenses, assesses its effect, and analyzes the conditions for issuing such licenses.

Key words: compulsory licenses, patenting, pharmaceutical patents.

doi: http://doi.org/10.15350/F_7/6

Российский рынок биотехнологий, в особенности, используемых при производстве фармацевтических препаратов, переживает не самые простые времена: большое количество широко известных в мире фармацевтики наработок до России не доходит, а та часть, которая доходит, реализуется в РФ по гораздо более высоким ценам. Это создает для отечественного законодателя соблазн создать препятствия для влияния зарубежных компаний на отечественный рынок.

Согласно установившейся практике после того, как срок действия патента на оригинальное лекарственное средство заканчивается, оно становится общественным достоянием, доступным для законной имитации компаниями - производителями дженериков, которые предлагают свой продукт потребителям по цене существенно ниже установленной производителем оригинального препарата.

В большинстве своем обсуждается недобросовестность дженериковых компаний, которые вместо добросовестного ожидания окончания срока действия оригинального патента пытаются его перехватить у патентообладателей преждевременно, нарушая тем самым их права. Особенно актуально это для сферы фармацевтического производства. В соответствии с устоявшимися воззрениями отечественной судебной практики и мировой практикой применения так называемой доктрины Болар считаются допустимыми приготовительные процедуры в виде регистрации дженериковыми компаниями лекарственного средства, в производстве которого будет задействован чужой еще действующий патент, так как данная процедура не нарушает законодательство, поскольку не связана с непосредственным производством и введением в гражданский оборот лекарства, составной частью которого является изобретение с еще не истекшим сроком патентной защиты. Однако на практике многие дженериковые компании, получая от Минздрава, не отягощенного обязанностью проверять патентную чистоту регистрируемых лекарств, регистрацию своего лекарства, оперативно производят партию лекарственного средства и продают его, нарушая исключительные права патентообладателя, поставленного таким положением дел в рисковую ситуацию.

${ }^{1}$ Gusarova Viktoria, Student, St. Petersburg State University of Economics, Russia.

Scientific adviser: Smirnov Vitaliy, PhD, Associate Professor, St. Petersburg State University of Economics, Russia. 
Эту проблему могло бы легко решить широко обсуждаемое создание Единого реестра лекарственных средств по примеру зарубежного аналога «Orange Book» в купе с возложением на Минздрав обязанности при регистрации лекарственных средств осуществлять мониторинг на предмет патентной чистоты лекарственного средства. А в случае обнаружения задействования в лекарстве дженериковой компании чужого патента с не истекшим сроком защиты должна осуществляться выдача регистрации под отлагательным условием, то есть выдача с установлением даты начала действия данной регистрации после окончания действия патента.

Категорически недовольна такой ситуацией на рынке Федеральная антимонопольная служба, которая видит выход в расширении возможностей выдачи принудительных лицензий с целью ограничения монополизации.

ФАС предложила внести изменения в ст. 1360 ГК, где предусмотрена возможность Правительства Российской Федерации в интересах обороны и безопасности разрешать использование изобретения без согласия патентообладателя. ФАС предлагает расширить возможности Правительства посредством предоставления ему права разрешать использование патентоохраняемых объектов без согласия патентообладателей в интересах жизни и здоровья граждан. Таким образом, ФАС предпринимает попытки получить инструмент для блокирования возможности компаний завышать цены на фармакологическом рынке. Это борьба со следствием, а не с причиной.

Такие намерения ФАС явно следуют из нынешнего поведения службы, которой еще не удалось лоббировать свои интересы, поскольку ее законодательные инициативы были встречены волной протеста не только патентообладателей, но и Роспатента, не поддержавшего данную законодательную новеллу. В качестве примера, можно привести напоминание ФАС англо-шведской компании «AstraZeneca» о возможности задействовать механизм принудительного лицензирования, если фармкомпания не снизит цены на некоторые препараты. В предупреждении, выданном 14 февраля 2018 г., говорится о необходимости снижения цен на некоторые из лекарственных препаратов, выпускаемых компанией. Среди них не имеют аналогов на российском рынке Золадекс (гозерелин) для лечения рака груди, матки и предстательной железы и Фазлодекс (фулвестрант) для лечения рака груди. ФАС обнаружила, что цены на них сильно завышены по сравнению с ценами за рубежом: на Золадекс - на 110\%, на Фазлодекс - на 75,5\% [1]. Однако на данный момент ст. 1360 ГК неприменима в сфере интересов здравоохранения, поэтому ФАС и пытается внести в нее дополнение. Но из подобного поведения ФАС уже явствует, зачем, на самом деле, истребуется законодательная новелла.

Многие компании-производители при оглашении ФАС данной законодательной инициативы выразили острую критику предлагаемой новеллы. И их положение понятно: выведение нового препарата на рынок занимает в среднем 10-13 лет [2]. К тому же это требует огромных затрат на разработки и тестирование. И осуществлять такие капитальные вложения компаниям интересно только при наличии уверенности, что за ближайшие 20 лет действия патента на изобретение вложения окупятся.

Пока ФАС приостановила свою инициативу по внесению поправок в статьи ГК, но этот факт не следует истолковывать, как решение ФАС ограничить сферу своей «креативности» [3]. Патентообладателям и Роспатенту следует внимательно следить за попытками ФАС лоббировать свои недобросовестные интересы, способные нанести урон отечественной экономике и науке. 
Практика показала, что принудительные лицензии используются, в первую очередь, в качестве протекционистской меры, направленной на развитие национальных дженериковых компаний, и только потом - для снижения цен на лекарственные препараты [4]. Формально получается, что выдача принудительных лицензий оказывает благоприятное влияние на национальный рынок, только этот положительный эффект не является доброкачественным, поэтому быстро сходит на нет. Вначале лекарственные средства, действительно, дешевеют, но впоследствии это приводит к оскудению рынка как такового - часть лекарств частные компании убирают с национального рынка, разорвав связи с ним, а другая часть может быть просто не разработана вследствие банкротства части компаний, лишенных доходов с патентов.

Образованное после государственного переворота, правительство Таиланда начало свою деятельность с попыток заполучить доверие и одобрение населения. В 2006 г. с этой целью оно выдало принудительную лицензию на «эфавиренз» - лекарственное средство, предназначенное для лечения ВИЧ, мотивируя это необходимостью снизить цены на указанное лекарство, являющееся труднодоступным для многих больных. На момент выдачи лицензии патент на указанный препарат принадлежал компании «Merck \& Co».

Что примечательно в данном случае, принудительная лицензия досталась государственной фармацевтической организации. Таким образом, произошла замена одного монополиста - правообладателя на другого - подконтрольное государству предприятие. Глобальный фонд борьбы со СПИДом, туберкулезом и малярией выразил свою готовность оплатить все расходы по закупке дженериковой версии «эфавиренза» из Индии. Однако тайские власти отказались от этого предложения, здраво понимая, что это создаст конкуренцию на национальном рынке, а их целью было закрепление монополии.

Ответная реакция рынка на произвол со стороны правительства ждать себя не заставила. Многие компании просто начали убирать с национального рынка свои лекарства. В качестве примера можно привести снятие с производство компанией «Аббот лабораториз» ряда лекарственных средств, в том числе и для лечения ВИЧ-инфекцией.

Казалось бы, это влечет для национального рынка только экономические затруднения в связи с оттоком производителей, но как оказалось, это далеко не единственное и уж точно не самое опасное следствие. Как показывает практика, лекарственные средства, производимые на основании принудительных лицензий, довольно часто уступают по качеству оригинальным препаратам. Некачественное лекарственное средство чревато возникновением резистентности: микроорганизмы-возбудители при неправильном воздействии на них обретают устойчивую к лекарственному средству форму, становятся невосприимчивы к действию патогенных факторов. В Таиланде дженериковая версия лекарства для лечения ВИЧ вызвала резистентность у 39,6-58\% пациентов. Теперь люди, у которых выработалась резистентность, вынуждены переходить на дорогостоящие препараты второго поколения, стоимость которых более, чем в 10 раз превышает стоимость препаратов первого поколения.

Таким образом, новая патентная политика правительства Таиланда, имеющая в основе благую цель - удешевление и обеспечение доступности жизненно необходимых лекарственных средств, оказалась роковой для части населения, у которой выработалась резистентность.

Второй опасностью можно назвать перспективу прекращение регистрации оригинальных лекарственных средств, связанную с использованием принудитель- 
ных лицензий. И если население рассчитывает на их замену более дешевыми дженериками, то этот механизм сможет работать только первое время. повлечет за собой прекращение притока дженериков, которые не смогут быть зарегистрированы при отсутствии данных об эффективности и безопасности оригинального препарата.

Таким образом, можно прийти к выводу, что использование принудительных лицензий в качестве протекционистской меры представляется не только целесообразным, но и опасным для экономики и уровня жизни населения. Существует мнение, что доступность лекарств для нуждающихся пациентов должна осуществляться с помощью иных, чем принудительные лицензии, инструментов, например: благотворительных программ, государственных закупок, снижения налогов и пошлин на ввозимые из-за рубежа препараты и т.п. [4]. И наблюдая опыт зарубежных стран в отношении принудительных лицензий, с данным мнением сложно не согласиться. Национальный рынок рискует спугнуть иностранные компании. Протекционистская политика государства должна проводиться за счет повышения качества изобретательского уровне отечественной науки, а не подавления зарубежных патентообладателей.

\section{References}

[1] Federal Antimonopoly service in the media: the FAS has threatened AstraZeneca with a compulsory license // https://fas.gov.ru/publications/14736

[2] Androshchuk, G. A. Compulsory licensing of medicines: problems and solutions // Patents and licenses. - 2014. - № 11. - p. 60.

[3] McDonald B.A.,Ugryumov V., Kolesnikov D. Compulsory licensing of pharmaceutical patents in the Russian Federation Threatens foreing \& Domestic drug developers // AIPLA Quarterly Journal - №1 - 2018. - p. 1-61.

[4] Kolesnikov D. S., Ugryumov V. M. Dangerous consequences of compulsory licensing of patents in the field of pharmaceuticals / / Patents and licenses - 2015. - №9 - p.39-51. 


\section{FINANCIAL REGULATION OF THE RENTAL HOUSING MARKET}

Yessenbaikyzy Inkar ${ }^{1}$

\section{Abstract}

This article provides information about the housing rental market. Compared with the experience of foreign countries, it is possible to achieve a specific goal. The influence of the housing market on the country's economy is reflected. The stages of development and the current state of this market are analyzed.

Key words: housing, market, purchase, investing, renting an apartment.

doi: http://doi.org/10.15350/F_7/7

В современных условиях вопрос улучшения рынка аренды жилья всегда был на переднем плане. Прежде всего, если мы определим понятие рынка аренды жилья, то это жилье (аренда), то есть квартиры, сданные в аренду (коммунальные) и частные (коммерческие), в аренду физическим и юридическим лицам за счет средств республиканского бюджета [1].

Чтобы оптимально подойти к теме рынка жилья, мы, как развивающаяся страна, поделимся опытом зарубежных стран в этой области, что поможет улучшить нашу экономику. Для этого мы должны придерживаться следующих принципов:

> исходить из базовых принципов экономики страны в управлении рынком жилья;

> Сотрудничество мирового уровня в области экономики и строительства;

> Использование результатов в различных областях промышленности на уровне управления.

В экономике рынок аренды квартир можно рассматривать как источник богатства и дохода. Жилье является прямым источником дохода с точки зрения объекта купли-продажи.

Например, с этого года только 3,3 триллиона тенге было инвестировано в жилищное строительство по программе «Нурлы жер». Следует отметить, что программы на рынке аренды жилья разные, у них свои правила. Если эти проекты будут реализованы и успешны, может быть проделана дальнейшая работа[2].

Рынок жилья в Казахстане может быстро развиваться, так как наша страна намерена вывести эту отрасль на международный уровень. Однако понятно, что этот вопрос также нуждается в поддержке государства.К сожалению, рынок аренды жилья занимает одно из последних мест из-за текущей ориентации на промышленность и другие области.

Самым прибыльным сектором экономики, в свою очередь, станет рынок недвижимости. Сегодня жилье стало инвестиционным инструментом. Все знают, что деньги должны храниться в безопасном месте. Это будет полезная инвестиция на пятнадцать, двадцать или даже пятьдесят лет для потомков вашей семьи, и сегодня

${ }^{1}$ Yessenbaikyzy Inkar, Undergraduate, L.N. Gumilyov Eurasian National University, Kazakhstan.

Scientific adviser: Khasenova Kenzhegul, PhD in Economics, Associate Professor, L.N. Gumilyov Eurasian National University, Kazakhstan. 
все больше людей хотят сохранить свои сбережения в этой области. Потому что его можно продать в любое время.Конечно, стоимость тенге в среднем может быть ниже его стоимости. Но это зависит от того, когда и где вы покупаете квартиру, потому что ценообразование является многофакторной доктриной. Эти факторы, в свою очередь, влияют на цену этого продукта.

Казахстанцы обращают внимание на различные подходы к инвестированию в жилье. Например, они занимаются покупкой и продажей квартир, арендой квартир или открытием собственного бизнеса. В основном, особый интерес к жилью. И если взять пример зарубежных стран, то стоимость съемных квартир и жилья намного дешевле. Инвесторы делятся на две группы: первая и те, кто покупает недвижимость на сумму от 40 до 120 миллионов тенге, вторая: те, кто тратит на недвижимость более 250-300 миллионов тенге. Эти средства достигают миллиардов. Первой, например, цель резидентов оборота таких квартир является постоянный спрос, который они рециркулируют после покупки квартиры.

Стоимость недвижимости варьируется в зависимости от ее местоположения. Рынок жилья в стране возродился с 2018 года. Соответственно, население, у которого есть сбережения в банке, получит жилье по программе. В этой области существует множество программ.Одной из важнейших задач государства является успешная реализация выделенных средств. Мы надеемся, что в будущем важные и качественные проекты будут реализованы и запущены на благо страны.

\section{References}

[1] Saginova B.K., Bimenova A.E., Economics of Real Estate., Almaty 2014., [Electronic resource] elibrary.kaznu.kz/

[2] [Electronic resource] - https://tengrinews.kz/ 


\section{METHODOLOGICAL ASPECTS OF THE EXPORT POTENTIAL FORMATION OF RUSSIA IN THE CONTEXT OF TRANSFORMATION OF THE EXTERNAL SECTOR OF THE ECONOMY}

\section{Andreev Oleg 1}

\section{Abstract}

The relevance of this article is predetermined by the existence of interdependent problems that have matured in Russia at the current stage of modernization of its economy, by the need to formulate an export strategy and adapt the country's economy to the conditions of entering the top five world economies. At the present stage, Russia is improving measures of investment, institutional and other policy areas that form the country's overall economic policy. The main components of scientific novelty are the stimulation of domestic exports, ensuring the demand for goods and services on a longterm basis, as well as the development of new types of industries with the expansion of the non-primary sector oriented to export. There is a need to develop an effective foreign trade development strategy for the country, since further measures to develop commodity markets play an important role in shaping the country's macroeconomic indicators.

Key words: innovation. export, export behavior, competitiveness, development strategy, world economy, export strategy.

doi: http://doi.org/10.15350/F_7/8

\section{Introduction}

The implementation of the national export strategy of the Russian Federation necessitates the creation of an effective public administration system and an adequate institutional environment.

One of the conditions for increasing the export potential of Russia is the implementation of the innovation development strategy and support for domestic industrial enterprises, taking into account the national component.

The strategic field of activity should be aimed at increasing investment in the ports of the world, what allows the country to own information on all trade operations, to expand knowledge and the prospect of participation in the global trade communication chain.

Investing in port terminals of the world should become a component of investment capital. This will allow to conduct a focused research on the study of investment opportunities in the ports of the world, to apply the experience of miscalculation management in the port business, as well as to negotiate with relevant departments to invest in this area.

To improve the export of domestic products, it is necessary to support highly innovative industries with a widely attracted range of investment capital, contributing to the expansion of export opportunities of the country's economy, as well as measures to increase labor productivity. We need training for specialists in high-tech industries, such as machine tool building, bioengineering, nanotechnology, automation, which can be

\footnotetext{
${ }^{1}$ Andreev Oleg, Ph.D. in Economics, associate professor, Department of Economics, Organization and Strategy for Enterprise Development, Samara State Economic University, Russia.
} 
trained in linked industries related to the service sector (logistics, certification and standardization, marketing promotion, etc.).

The transfer of technology and knowledge should become a new tool for the technological development of production. To improve the situation in the country, a national concept is needed to conduct research and practical application in the field of standardization and certification. In order to upgrade the technological base of production, the latest technological equipment should be provided through investment projects on a leasing basis, which should be accompanied by a package of new services for the manufacturer.

The foregoing indicates the need for a thorough study of the formation of export potential from methodological positions.

The use of economic development mechanisms in the context of Russia's integration into the global economy indicates the urgency of developing the country's export potential

\section{Methodology}

In modern economic literature there are various methods for assessing export potential and its competitiveness. Methodological aspects were considered in the studies of the authors of Bernard et al., Farole et al., Meilien and Sniesko, Mikael P. Todaro, Paul R. Krugman, Morris Obstfeld, Thomas A. Pugel, Peter H. Lindert, J. Stigler, Maurice Allais, F. Justster, E.M. Aghababyan.

Works of J. Robinson, V. Nordhau, P. Samuelson, R. Solow, J. Stigler, L. Erhard are focused on maintaining the sustainability of macroeconomic processes.

In the work of J. M. Keynes, A. Muller-Armak, I. Kant, V.N. Khrapanyuk and others are devoted to the need to regulate economic processes. Their studies on state regulation and substantiation of the functions of the state in the economy are relevant now.

Research questions involve the formulation of specific tasks, without the resolution of which it is impossible to realize the plan. There are issues that can be solved through existing scientific data (for example, methodological). Moreover, many scientific results need to be refined using modern approaches [1].

It should be noted that the directions of the theoretical and methodological substantiation for ensuring sustainability at the national, regional and sectoral levels and the study of ways to create export potential are insufficiently studied. In economic studies, the problems of export potential in the context of globalization have not yet received adequate coverage. The level of scientific knowledge in the country in the field of export potential is not sufficient to solve fundamentally new problems and problematic issues.

In this regard, research in this direction can increase the competitiveness of the country's organizations, which will affect the formation of export potential.

The formation of export potential requires the systematization of different views, therefore it is legitimate to introduce the essence of export potential into existing interpretations, which allows us to highlight several points of view [2].

So, scientists consider the export potential as a qualitative characteristic of the national economy, that is, the potential ability of a country to export products, resources that are currently available or produced, ranking factors such as sources, reserves, funds and opportunities as an object of export.

It is rightfully to consider the characteristics of the export potential from other perspectives: as a complex multifaceted phenomenon, which is revealed with simultaneous perception of it as an "indicator", "process", "behavior", a quantitative characteristic of the economic parameters of economic development.

Consideration of the export potential as a special process makes it possible to reflect the "process nature" of production and the export activity itself. 
So, O'Donnell considers marketing opportunities for export potential [3], which is more relevant than ever in modern conditions, since export potential reflects the process nature of production and export activities.

A. Buckley et al. Consider export potential as a certain process that determines the presence of factors such as labor costs, productivity, prices and R\&D [4].

In practice, often export potential is used as an "indicator" of economic potential.

$\mathrm{Yu}$. Savinov et al. [ 5 believe that this indicator should take into account the market for the possible sale of its goods, since export potential is, first of all, the ratio of exports to total sales.

In modern economic science there is also such an understanding as "exportbehavior", which characterizes marketing innovations.

Castro et al. made an attempt to determine how much export value and productivity together can determine intra-company export behavior [2].

M. Thomas and L. Araujo consider export behavior as an innovative strategy [7].

In our opinion, in the economic literature, opinions on choosing the optimal export strategy differ.

But in the economic literature, opinions on choosing the optimal export strategy differ. A. Smith, D. Ricardo, Heckscher-Olin, and Samuelson argue that countries should specialize in manufacturing and exporting in accordance with their comparative advantages.

This argument was supported by empirical evidence of E. Helpman and P. Krugman, R. Housman, D. Rodrik. These authors adhere to the export specialization strategy. They emphasize that this nature of specialization is gaining importance as specializing in this type of export of products, which may be accompanied by a deterioration in economic indicators.

Under conditions of uncertainty in general, global trade will decline, as commodity producers are at risk of declining output.Other arguments in favor of export diversification include mitigating the vulnerability of countries to economic shocks (such as volatility and instability of export operations; reducing the fluctuation in economic growth in countries) that open up to trade.

The export strategy based on the global value chain (GVC), implemented through the country's accession to the GVC, is being modernized by the inclusion of additional internal added values.

According to supporters, despite the similarities with the industrialization strategy, there is a difference (A. Hirschman in the late 1950s), which consists in the constant search for microefficiency that controls GVCs around the world, which is a condition for the long-term sustainability of GVCs modernization strategies.

The GCCs modernization strategy more often implies an increase in internal intersectoral relations. This strategy is sustainable in the long run if new domestic suppliers can effectively replace foreign ones.

The essence of export potential is not represented in the economic literature. Therefore, the content is more fully revealed when characterizing its types, which are differentiated by spatial (regional and global), temporal (realized and unrealized), qualitative (level of competitiveness) signs and levels.

In the scientific literature, special attention is paid to spatial concepts, including the "regional" or "world" levels.

In this regard, "export potential" means the ability to produce the required amount of export-oriented goods that would meet the quality of the needs of the external market region. Accordingly, we can assume that the export potential of the country is made up of the export potentials of individual industries. This concept also includes the company's 
ability to find partners in foreign markets, the ability to conclude mutually beneficial contracts for the provision of services necessary for consumers.

Temporal characteristics distinguish between realized and unrealized potential.

The realized export potential, in our opinion, assumes that the goods or services have been successfully identified and they entered the foreign market.

The unrealized export potential implies that export outside the country is not possible for objective and subjective reasons.

We believe that this phenomenon lies not only in the realization of market opportunities, but also in the ability to form a mechanism for future development and implies the presence of internal capabilities to adapt the system to changing external conditions.

In different periods, the transformation of export potential took place.

Many scientists support the idea of a significant level of the relationship between technology and export, but the scientific value of technology for competitiveness does not always depend on its use in manufacturing products. It is important what technologies and how they were used.

According to M. Tarasov, technologies as a competitive advantage are considered as a link in the chain of value creation factors [10].

Competitiveness issues need to be addressed through new technologies. Emphasis needs to be placed on upgrading existing technologies through the promotion of green technologies and organic products. Thus, a gradual transition of the industrial structure of the economy to "bioeconomics" is important for Russia. For this, the country has all the natural conditions: vast territory, natural resources and organic intermediate products.

Uchida and Cook, analyzing the commercial and technological advantages of Asian countries, note a significant difference in them, associated primarily with the structure of industry, the relationship between technology and industry structure.

The impact of innovation on export potential does not occur directly, but through impact on the industry. Innovations have become an economic resource in determining the competitiveness of industry, although previously they were only considered as its source.

Thus, the accumulation of changes is necessary to obtain as a result of a major technological breakthrough. An innovation policy will be effective if there is a systematic relationship between two main areas: the stimulation of human potential and the development of an innovative type of business sector. The fact that innovations in some countries are applied mainly due to foreign direct investment negatively affects innovative development.

Lee explains that each economic system has certain institutions - social, economic, political, through which the conditions for competition between market participants are formed.

A number of scientists in their works apply an integrated approach to determining the parameters of export potential.

B. Khusainov offers an approach to identify the comparative advantage of exports by including additional indicators in the production and consumption of products [9].

J. Brunekiene and D. Paltanavikine [14] believe that using the index is the best way to measure export competitiveness.

J. Mikulis and J. Ruzevikus emphasize the development of a model for measuring export competitiveness through export competitiveness factors and their characteristic indicators.

The methodological approach is predetermined by the parameters characterizing the export potential as the ratio of exports to total sales, the share of competitive export 
products, the ratio of exports to the domestic market, exports as a percentage of total production, as well as export volumes.

There are still debatable issues of quantitative assessment of barriers and determining the effects of influence on export potential.

This problem was considered by such researchers as Didov, Maskus, Naylor, who developed a number of methods that make it possible to measure barriers to the realization of export potential and assess their impact. The most common methods are determining the frequency of use, the price gap, i.e., the price or tariff equivalents of NTBs, simulation of foreign economic activity.

The analysis of the existing literature on competitiveness reveals a wide range of concepts and the extreme difficulty of applying various techniques to measure these barriers.

Theoretical and practical issues of export productivity are analyzed in the studies of Hausman et al. In these studies, improving the export structure was associated with diversification, which includes improving export quality and is measured by export productivity [3].

There are several models used by different groups of countries:

- an industrial model of export development using an assortment strategy;

- an investment model for the development of exports, involving the use of various investment strategies;

- a market model for export development using a market penetration strategy;

- a modernization model of export development based on productivity.

To increase export potential by expanding the market, analysis is needed to assess and select a market for promoting export flows from a country where Q1 is the possibility of expanding exports for existing goods and Q2, in addition to existing goods, the possibility of expanding the export of new goods in new markets.

There are ways to diversify the goods, that is, to diversify goods by creating other, not similar to each other, through the production of related goods.

\section{Results}

Houseman and Klinger take the "product space" model as the basis for determining export potential.

The results of the analysis will help answer the question, what are the opportunities in the country's economy for transformation. The calculation is as follows: the level of comparative competitive advantages of goods is determined by the Balass method according to the following formula (1):

$$
R C A_{2}=\frac{\left(X_{i j}-M_{i j}\right)}{\left(X_{i j}+M_{i j}\right)}
$$

where $\mathrm{M}_{\mathrm{ij}}$ - import of product $\mathrm{j}$ into country I, and then the distance between goods I and $\mathrm{J}$ in the year $\mathrm{T}$ is measured, where this distance is called "proximity", it is equal according to formula (2):

$$
\varphi_{i, j, t}=\min \left\{P\left(x_{i, t} \mid x_{j, t}\right), P\left(x_{j, t} \mid x_{i, t}\right)\right\}
$$

where for any country according to the formula (3):

$$
x_{i, c, t}=\left\{\begin{array}{lr}
1 & \text { if } R C A_{i, c, t}>1 \\
0 & \text { otherwise }
\end{array}\right.
$$


A country's ability to transition to new products depends on whether it is easy to reorient its existing potential to the production and export of new products. For example, if Malaysia exports microwave ovens, and Chile specializes in exporting salmon, then in the first case, a deep knowledge of electronics and technology is required, in the second, knowledge of biology and veterinary medicine. And it's hard to say which of the methods leading to increased economic growth is more advanced or complex.

Thus, it is easier for export to establish the production of a related product than not at all similar, which may require such capabilities that the country has not yet accumulated for its production, which makes it possible to identify:

-how it is possible to replenish the existing export basket with new goods so that they are successfully exported and competitive;

-it makes it possible to trace the relationship between existing and new products through the concept of "distance".

Currently, there are modified versions of the Husman-Klinger method, but it has limitations.

According to the product space model, the choice of a new product is based on the accumulated capabilities of the country, however, the accumulated opportunities are not always the result of the implementation of a well-thought-out policy of the country in the formation of the export basket.

Based on the existing opportunities and available resources in the country, it is easier to reorient to "close" goods, which will provide the export basket with a clear advantage (under the concept of available opportunities and resources, we can consider human potential, institutional opportunities, export basket, etc.)..

Additional parameters are also needed, such as the state of demand for goods in the foreign market and domestic production capabilities.

In the absence of a universal method for assessing export potential, different methods can be applied and interconnections between their indicators can be established.

Therefore, one of the important principles of trade policy is functioning countries in market conditions, whose trading activities include a non-discriminatory basis in relation to the partner. Therefore, public policy should operate on the principles of legitimacy of the measures taken, transparency and justice in relation to partners.

\section{Conclusion}

Export, like import, is a product of a separate stage of the technological process. The implementation of intra-industry trade opens up opportunities for the mutual exchange of innovations and technologies, increasing the economic potential, searching for new directions in terms of differentiating the product range, liberalizing foreign trade, and eliminating barriers in foreign trade, lower tariff rates, growth in foreign direct investment.

Expanding market coverage for products that have proven to be competitive in some export markets can be an important channel for improving export assortment.

In modern conditions, it is supposed to transform the export model and transfer it to a new level - the level of innovative development.

In the process of research, the need arises to differentiate the results of export analysis by industry and country and present them in an aggregated form, as well as to identify promising niches and markets for promoting export products of a group of goods that have comparative advantages of the Russian Federation in certain markets.

The main trends in the development of foreign trade of Russia:

- the value of exports has decreased sufficiently;

- the physical volume has significantly decreased, but not so rapidly; 
- the range of exported goods has increased;

- there were structural changes in the export basket. istics:

Export potential can be assessed in terms of quantitative or qualitative character-

-quantitative characteristics - "volume and growth" of exports,

•qualitative characteristics - "competitiveness", "diversification", "productivity" of exports, etc.

By identifying the quantitative and qualitative characteristics of exports, it is possible to determine the level of development of export potential by a certain indicator, a change in competitiveness, an increase in export volume, etc.

A study of the main factors affecting exports made it possible to identify the nature of their influence on the country's economic indicators. follows:

The ranking of influencing factors on the export of products is presented as

- the factor of natural resources has recently lost its significance;

- the fluctuation of the national currency as one of the components of the macroeconomic environment of the country causes mixed estimates;

- the role of the institutional environment is decreasing.

New technologies, innovations and government measures stimulating exports can have a qualitative impact on exports.

But no method can independently assess the export potential, since they are components of a systemic methodology that determines the sequence of their use, establishes their relationships, which ultimately makes it possible to get the most comprehensive analysis of the country's export potential.

In this regard, the creation of the so-called "block model" is required, which includes a combination of several models, since it is difficult to cover the above goals with one model.

Thus, the choice of assessing the export potential acceptable for Russia involves the development of methods, the results of which should give answers to questions such as:

-to improve the volume and growth of export products and the volume of work associated with export activities;

-to diversify the commodity structure of export products and expand sales markets;

-to improve the quality of export products and the quality of work related to export policy.

Currently, new technologies are being introduced in the global economy that can affect the development of such areas of the economy as the communications industry, aviation, metallurgy, construction, energy, agriculture, bioengineering, mechanical engineering, etc. New types of technologies are already being introduced: FIN-tech ; cyber technology; hydrogen fuel cell vehicles with zero emissions; next-generation robotics working remotely from the manufacturing process; recyclable thermosetting plastics new types of plastic for cutting field waste, computer chips that mimic the human brain; replacement of metals with other forms of materials, the digital genome, etc.

Recommendations on improving export policy, which can help accelerate economic growth and further develop foreign economic activity of Russia as a factor of integration into the world economy.

\section{References}

[1] Ermakova A.A. Theoretical approaches to the definition of the concept of "economic potential" // Young scientist. - 2016. - No. 10 (114). - P. 15-19. 
[2] Zemtsov S., Barinov V. The paradigm shift of the regional innovation policy in Russia: from leveling to clever specialization // Issues of economics. - 2016. - No. 10. - P. 65.

[3] O'Donnell M., Turner M. Exporting new public management: performance agreements in a Pacific microstate // International Journal of Public Sector Management. - 2005. - Vol. 46, №7. - P. 615-628.

[4] Barkley D. Evaluations of regional competitiveness: making a case for case studies // http://journal.srsa.org/ojs/index.php/RRS/article/view/158/107.

[5] Savinov Yu. et al., Export potential of the industry for the development and marketing of information and communication technologies // Russian Foreign Economic Bulletin. - 2013. No. 6. - P. 28-40.

[6] Mancini-Griffoli T., Pauwels L. Is there a euro effect on trade? An application of end-of-sample structural break tests for panel data, IHE: working papers / The Graduate Institute of International Studies. - Geneva, 2006. - Vol. 4. - P.1-31.

[7] Thomas M., Araujo L. Theories of Export Behaviour: A Critical Analysis' // European Journal of Marketing. - 1985. - Vol. 19, №2. - P. 42-52.

[8] McCreadie K. Smith's A. The wealth of nations: A modern-day interpretation of an economic classic. - Oxford, 2009. - $126 \mathrm{p}$.

[9] Ricardo D. On the principles of political economy and taxation. - ed. 3 // http://www.efm.bris.ac.uk/het/ricardo/Principles.pdf.

[10] Tarasov M. et al. Competition and competitiveness of economic entities in economic sectors: lecture course. - Yakutsk, 2014 - - 334 p.

[11] Álvarez I., Marin R., Fonfría A. The role of networking in the competitiveness of firms // Technol. Forecast. Soc. Change. - 2009. - Vol. 76, №3. - P. 410-421.

[12] Thompson E.R. National competitiveness: A question of cost conditions or institutional circumstances? // Br. J. Manag. - 2004. - Vol. 15, №3. - P. 197-218.

[13] Lee C. An institutional perspective of national competitiveness // Singapore Economic Review. - 2010. - Vol. 55, №4. - P. 671-683.

[14] Bruneckiene J., Paltanaviciene D. Measurement of export competitiveness of the Baltic States by Composite Index // Engineering Economics. - 2012. - Vol. 23, №1. - P. 50-62. 


\section{KINDS OF INNOVATION STRATEGY AND RISKS OF INNOVATIVE ACTIVITY}

\section{A. Adashev ${ }^{1}$}

\section{Abstract}

In this scientific article innovative activity is considered, the essence and functions of innovation are analyzed.

Key words: investment, innovation, labor, service, management.

doi: http://doi.org/10.15350/F_7/9

The risk in innovation is the danger that the goals set in the innovation project may not be achieved in full or in part.

In the place of origin different types of risks are allocated: industrial, commercial, financial, competitive.

By the nature of the impact, the risks are divided into simple and compound.

Composite risks are a composition of simple risks.

Simple risks are determined by a complete list of non-overlapping events, that is, each of them is considered as not dependent on others.

In this regard, the first task is to compile an exhaustive list of risks; The second task is to determine the proportion of each simple risk in their entirety.

Examples of the most significant compound risks:

- External economic risk (the possibility of introducing restrictions on trade and supplies, closing borders, etc.);

- the risk of adverse socio-political changes in the country or region; Uncertainty of the political situation;

- the risk associated with the instability of economic legislation and the current economic situation;

- risk of fluctuations in market conditions, prices, exchange rates;

Examples of simple risks as a result:

- lack of necessary workers;

- Insufficient skills of available employees;

- remoteness of technical networks;

- late delivery of equipment;

These risks are inherent in any business, regardless of the presence in the entrepreneurial project of an innovative component.

There are a number of risks encountered exclusively in innovative entrepreneurship:

It consists in the fact that investing in "breakthrough technologies" is very risky from the point of view of guaranteeing the necessary result, i.e. A really new interesting technology or product.

In Russia there are quite a lot of technologies that have been developed for a long time, but interest to them appeared only today. The developers, often quite sincerely, talk about these technologies as existing ones, and even demonstrate the samples obtained 510-15 years ago. However, it often turns out that the equipment on which the samples were made has deteriorated over the years, part of the development team has retired, and the technology, alas, is no longer reproducible

${ }^{1}$ A. Adashev, Head teacher of the Department of «Management», Namangan Engineering Construction Institute, Uzbekistan. 
There is a fundamental difference between technology as a product of intellectual activity and technology as an object of investment. Technology becomes investment attractive not when it exists, and not even when it can be embodied industrially (which is not always possible to provide), but when it is in demand by the market

The combination of insufficient legal protection of intellectual property with the uncertainty of the rights to develop, especially those created under the Soviet regime, and elementary legal illiteracy often leads to cases where the authors of technology or refuse to disclose some features of their product, thereby discouraging the possibility of investing in it, or They do not comply with their obligations, especially in terms of exclusivity and confidentiality.

It consists in the discrepancy between the content of the investment project and the financial resources necessary for its implementation.

As you know, the equally important components necessary for the successful implementation of the investment project is the originality and thoroughness of the project itself, the team's qualification and cohesion, which the project will implement. In Russia, and not only these components are in some contradiction with each other, since the professional qualities necessary for developing the original technology and its industrial implementation are very different. A scientific leader who led his team to develop a unique technology may well be untenable as a leader and the project ends with nothing.

It consists in the possible difference between the ultimate goals of the investor and the management of the enterprise implementing the project. The investor wants, as a rule, or tomorrow, but a lot, or not very much, but every day, i.e. Pursues strategic goals. Unfortunately, the management of the enterprise has much shorter breathing, it wants at least something, but today. And the investor needs a fairly serious effort to implement its strategy in the enterprise. And given the Russian legislation, especially Russian practice, when the actual owner of the enterprise is its director, and not the owner, these difficulties rarely become surmountable.

\section{References}

[1] Innovative management / Ed. S.I. Ilyenkovoy - M .: Unity, 2001.

[2] Innovative management / Ed. LNOgolovoy - Moscow: Infra-M, 2001.

[3] Kokurin D.I. Innovative activity. - M .: Examination, 2001.

[4] Adashev, A. U. (2018). MODELS OF TRANSITION TO MARKET ECONOMY, THEIR COMMONWEALTH AND DIFFERENCES. Экономика и социум, (2), 8-11.

[5] Akhmedov, O. T., \& Adashev, A. U. (2018). ANALYSIS OF INVESTMENT PROCEDURES IN THE DEVELOPMENT OF THE BUILDING INDUSTRY. Economics and Innovative Technologies, 2018(1), 15.

[6] Adashev, A. U. (2017). The content bases of the innovative development in companies. Высшая школа, (3), 10-11.

[7] Адашев, А. У., Аскаралиев, А., \& Узбекистан, Н. (2017). СовРЕМЕННЫЕ ПоДХоДЫ К ПоКАЗАТЕЛЯМ И ЦЕННОСТЯМ ЭКОНОМИЧЕСКОГО РАЗВИТИЯ. Теория и практика современной науки, (2), 28.

[8] Адашев, А. У. (2016). Значение малого бизнеса и частного предпринимательства в вопросах занятости. Молодой ученый, (10), 573-575.

[9] Mamajonova, G. K. (2019). The role of bioethics in fostering the family's spiritual foundations. International Journal of Advanced Science and Technology, 28(12), 397-401.

[10] Mamazhonova, G. K. (2019). ROLE OF BIOETHICS IN THE DEVELOPMENT OF MEDICINE AS A CULTURAL FORM. Scientific Bulletin of Namangan State University, 1(7), 164-169.

[11] Mamajonova, G. K. (2019). Bioethics-Institutional Mechanism of Social Control of Criteria for Ethical Choice and Ethical Responsibility. Journal of Sources of Science, (5), 30-33.

[12] Shakirova, G. S., \& Mirzaabdulayeva, G. M. (2019). The relationship between the development of science, technology and innovation. ACADEMICIA: An International Multidisciplinary Research Journal, 9(3), 27-33. 


\section{CULTURAL SCIENCE}

\section{ART THERAPY IN SPACE OF MODERN CULTURE ABSTRACT}

\section{Davtyan Vardan ${ }^{1}$}

\section{Abstract}

Art therapy is the softest and at the same time the deepest method in the arsenal of psychologists and psychotherapists. It is associated with the disclosure of creative opportunities and the identification of hidden reserves of an individual. As a result, people find effective ways of the solution of their difficulties. Art therapy is a path leading to the depths of the psyche. By depicting the problem and mood through the drawing, modeling or writing description, a person as if receives an encrypted message from his subconsciousness. A man can solve many problems on his own, become his own psychologist, assess his own mental states, the manifestation of emotions, appropriately managing his own behavior.

Key words: art therapy modern types, art, origami.

doi: http://doi.org/10.15350/F_7/10

Искусство как терапевтический метод дает выход внутренним эмоциям, конфликтам, помогает интерпретировать вытесненные желания и переживания, повышает самооценку личности, развивает творческие способности. Искусство это не только мастерство и техника построения образа, но и, в первую очередь, отражение личности творца в художественном произведении. Именно эта мысль положена в основу работы психолога, применяющего технику арт-терапии. Человек творит: рисует, гравирует, пишет, - выражая свой внутренний мир, свои осознанные и неосознанные стремления. Некоторые психологи считают, что терапевтическое воздействие оказывают по-настоящему хорошие произведения искусства, носителями истины, добра и красоты являются произведения искусства, которые имеют высокую художественную ценность. Поэтому человек должен стремиться выразить свои душевные состояния в хорошо выполненной картине, хорошо написанном эссе и т.д.

Другим возможным механизмом является то, что творческий процесс можно рассматривать как исследование реальности, обнаружение еще нераскрытого нового. На ранних стадиях своего развития в арт-терапии отражались психоаналитические воззрения, согласно которым художественная деятельность клиента рассматривалась как неосознанное выражение психических процессов. Привлекательность арт-терапии в главном для современного человека состоит в том, что данный способ в главном употребляет невербальный метод общения и самовыражения. В процессе творчества деятельно задействуется правое полушарие мозга. Сегодняшняя же культура использует основным образом вербальную си-

\footnotetext{
${ }^{1}$ Davtyan Vardan, Graduate student, Departments of Theory and History of Culture, FSEI HPE of the St. Petersburg Institute of Culture and Arts, Russia.
} 
стему общения и левое «логическое» полушарие. Природное, гармоничное развитие человека имеет необходимость в одинаковом формирование двух полушарий и обычное межполушарное взаимодействие. Арт-терапия основывается на внутренние, самоисцеляющие ресурсы человека, тесновато связанными с его креативными способностями.

В креативных работах, как правило, отражены методы взаимодействия с природой. Переживая образы, человек обретает собственную целостность, неповторимость и особенность. Еще, разрешено использовать другие формы художества - театральные постановки, импровизации, литературное творчество. Таким образом, достигаются следующие цели [1]:

1) Дать социально приемлемый выход агрессии и другим негативным эмоциям;

2) Облегчить процесс психорегуляции, поскольку внутренние неосознанные конфликты и страдания часто легче выразить через образные формы, чем в ходе вербального общения.

3) Получить материалы для интерпретации и диагностики.

4) Проработать привычные для пациента мысли и чувства.

5) Сгладить отношения между психологом и пациентом. Совместное участие психолога и пациента в художественном творчестве будет способствовать развитию эмпатии и взаимопонимания.

6) Развивать чувство внутреннего контроля.

7) Сосредоточить внимание на ощущениях.

Участие в творческой деятельности создает большие возможности для проверки кинестетических и визуальных ощущений.

8) Развивать художественные навыки и повысить самооценку.

Инновационная научная арт-терапия, как это не удивительно, при всем своем многообразии взаимосвязей с культурными прецедентами теснее всего стоит к варварскому, «простому» старейшему художеству. Оно, как и арт-терапия базируется на неожиданном самовыражении и пренебрегает все эстетические аспекты в оценке его итогов и мастерства создателя. Поэтому как, наиболее важен процесс творчества, а не итог.

В арт-терапии принципиальным мнением считается сублимация - представление желаний и машинальных инстинктов (время от времени деструктивных) с поддержкою трансформирования их в творения художества. Художество имеет возможность «навести и в иное русло» и проявить эти ощущения как: злоба, болезнь, тревогу, ужас.

Преимущественные стороны метода арт-терапии [2]:

1.Отчуждает вероятность для выражения брутальных эмоций в общественно - применимой стилю. Живопись, живописание красками либо лепка считаются не опасными методами разрядки напряжения;

2.Убыстряет успех терапии. Личные волнения и подсознательные инциденты свободнее выражаются с поддержкою зрительных образов, нежели в беседе (вербальной психотерапии). Невербальные виды общения имеют все шансы с большей возможностью избежать намеренной цензуры;

3.Дает причины для диагностической работы и интерпретации в процессе терапии. Творческая продукция сообразно фактору ее действительности не имеет возможность отказываться больным. Манера художественной работы и ее оглавление предоставляют терапевту грандиозную информацию, не считая такого, сам создатель имеет возможность привнести взнос в интерпретацию собственных личных творений;

4.Дает вероятность действовать с эмоциями и думами, которые кажутся непреодолимыми (гибель, утраты, перенесенное принуждение и травмы, внутрен- 
ние инциденты, ужасы, мемуары из юношества, сны). Время от времени невербальное лекарство как оказалось единым инвентарем, разрезающим и проясняющим функциональные впечатления и убеждения;

5.Содействует укреплению терапевтических отношений. Единые элементы в художественном творчестве членов категории имеют все шансы убыстрить формирование позитивных эмоций и эмпатий;

6.Способствует выходу в свет ощущения внутреннего конроля;

7.Производит и увеличивает интерес к эмоциям;

8.Увеличивает чувство своей личной ценности, усиливает художественный профессионализм. Итоговым продуктом терапии художеством считается довольство, образующаяся в итоге раскрытия укрытых умений и их становления.

В числе современных средств и направлений в арт-терапии все ярче и ярче говорит о себе, такое многообещающее направление как - оригами.

Оригами - обычное японское искусство, проектирование разных бумажных фигурок способом складывания квадрата в отсутствии вырезания и слипания. Это художество все более интегрируется в мировую культуру, делается предметом исследования профессионалов таковых сфер, как проектирование, математика, структура, промышленный дизайн, фактическая психология, педагогика, и арт-терапия. В данный момент, оригами как способ арт-терапии с фуррором употребляют в реабилитационной и целебной практике врача самых различных квалификаций. Очень много исследований говорят о том, что занятия оригами облагораживают свойство жизни нездоровых, подсобляют забыть болезнь и несчастье, увеличивают самооценку, убавляют степень тревожности, содействуют налаживанию дружественных взаимоотношений, взаимопомощи в коллективе, подсобляют определить контакт между больным и доктором. Потому, в арт-терапевтической практике возникает новейший термин - «образ жизни оригами».

Занимаясь оригами, клиент принимает участие в захватывающем деянии превращает бумажный квадрата в необычную фигуру - цветочек, бабочку, динозавра, коробочку. Данный процесс припоминает фокус-покус, маленькое понятие, что постоянно вызывает удовлетворенное изумление. Возникает желание представить кому-нибудь это волшебство, изготовить что-то еще. Теряется эмоция обособленности, налаживается обращение, в том количестве и больного с доктором, что считается в особенности принципиальным, когда клиент - малыш. Время от времени бывают случаи, когда детки, в состоянии волнения, ужаса отрешаются воспринимать медикаменты либо пищу. Тогда на содействие прибывает арт-терапевт с куколкой в руках и неосуществимое делается вероятным. Схожей «волшебной палочкой» имеет возможность стать оригами. Однако далековато не в любом целебном заведении отыщется специалист по куклотерапии, когда занятия оригами доступны фактически всем, правда и бумага имеется постоянно перед рукою. Оригами отлично используется в том числе и при аутизме.

В многих странах мира, где уже применяется оригами, утверждают, что такие занятия имеют позитивное влияние на эмоциональное состояние больных, снимают депрессию, увеличивают уверенность в личных силах, содействуют установлению дружественных контактов, которое делает лечение наиболее действенным и улучшает психическое состояние больных. Неповторимость арт-терапевтического воздействия оригами содержится еще в том, что даже при полной изоляции, человек может вести диалог с личным разумом, что приносит ему большое удовольствие.

Обобщая можно сказать, что сегодня художественная терапия и терапия искусством приобретает огромную популярность. 


\section{References}

[1] Kopytin A.I. Art therapy in a comprehensive school. Toolkit. St. Petersburg: Academy of Postgraduate Pedagogical Education, 2005.

[2] Semenyuk, L.M. Psychological features of aggressive behavior of adolescents and the conditions for its correction [Text] / M .: Flint, 2008. - p. 65. 


\section{THE „THE KNIGHT IN THE PANTHER'S SKIN,, AND CULTURAL PARADIGMS OF GLOBALIZATION}

\section{Nino Giorgadze 1 \\ Isako Meparishvili}

Kartvelological studies in Europe mainly started in the 50-s of the XIX century. French scholars are given priority in this regard. With their assist, French people were the first nation who became aware of Georgian spiritual and material culture, as well as the Georgian history. Together with the French, Goethe's compatriots i.e. the German people were also attracted by Rustaveli's poem. Studies of German scholars may have been schematic, inaccurate at that times, but they were of great importance in terms of popularizing the "The Knight in the Panther's Skin,, and forming Georgian-German relations.

Literature is the service of an exalted and wonderful spirit. The soul is divine in man. His role is being close to God. Shota Rustaveli came close to God because his own concept related to "ONE" is given from the perspective of world cultures.

Key words: "The Knight in the Panther's Skin,,, Shota Rustaveli, Globalization, World, Paradigms.

doi: http://doi.org/10.15350/F_7/11

Kartvelological studies in Europe mainly started in the 50-s of the XIX century. French scholars are given priority in this regard. With their assist, French people were the first nation who became aware of Georgian spiritual and material culture, as well as the Georgian history. The first European who aimed to conduct a thorough study of Georgia with its past history, culture and literature was the French scientist Marie Brosset. He did his best to deepen and develop the Georgian-French cultural relationship, and undertook a comprehensive study of the great Georgian writer Shota Rustaveli and his famous poem "The Knight in the Panther's Skin,, in France. Marie Brosset can be considered as the first foreign scholar in the field of Rustaveli studies. Later, other scholars such as A. MarcelPaon, E. Jaloux, L. Aragon, R. Lacotti, A. Kayau, R. Lafon, A.Lanu, e. Gievik, P.Gamara etc continued their studies in this field.

Together with the French, Goethe's compatriots i.e. the German people were also attracted by Rustaveli's poem. Studies of German scholars may have been schematic, inaccurate at that times, but they were of great importance in terms of popularizing the "The Knight in the Panther's Skin,, and forming Georgian-German relations. F. Fink and 0. Hauser were the first German scholars to pay particular attention to Shota Rustaveli's poem. One cannot also recall A.Laist, A.L. Zunter, whose role is important in forming correct, scientific conclusions and views in Rustvelology.

The scientific study of the poem "The Knight in the Panther's Skin,, has, to some extent, strengthened the cultural and scientific links between England and Georgia. William Richrard Morfill, professor of Oxford University had a great contribution in this regard. Important researches about the issues of the Georgian literature, as well as Shota Rustaveli by 0 . Wardrop, started to appear in the scientific field of that time. Studies by

\footnotetext{
${ }^{1}$ Nino Giorgadze, Associate Professor, Head of Department of Georgian Philology, Iakob Gogebashvili Telavi State University, Georgia.

${ }^{2}$ Isako Meparishvili, Associate Professor, Iakob Gogebashvili Telavi State University, Georgia.
} 
M. Wardrop, W.Allen, S. Shimansky and the researches of later period by D. Lang are of great importance. Fortunately, the list of scholars in this field is numerous.

We needed to make the brief review to make it clear that the masterpieces like the "The Knight in the Panther's Skin, can't be consumed by the space and time. They never remain in the frames of their epoch.

European scholars also believe that Rustaveli is a universal poet as he belongs to the whole world. "The Knight in the Panthers Skin,, is a poem in which people sob, express happiness, revel and support the principle that life is worth fighting for. This is the poem which proves the idea that "the joy of being a human is major in life".

The preoccupation of the author and his famous poem is a human's inner world and the variety of human's character. Values are overthrown overtime. People are being changed; consequently their esthetic values are changed as well. Such kind of mentality leads to the world culture. Religious, political, ethical, philosophical ideas eventually create cultural integrity, cultural coexistence. This fact is proved and explained by the reality that the poem "The Knight in the Panthers Skin" has been translated in various languages. It is noteworthy that the Europeans not only translated the poem but also thoroughly researched the poem-related issues, studying the Rustaveli era, politics, and culture of that period. The result of such a professional approach is the recognition and acknowledgment of many scholars. E.g. Louis Aragon considered the "The Knight in the Panther's Skin,, as the most magnificent masterpiece of the Middle Ages". In his opinion: "No one sings for love better than Rustaveli does" (Aragon, 1976, 80).

One cannot avoid the idea expressed by Rachel Zinovievna Miller-Budnitskaya: "The Renaissance of Western Europe must be revised: it is originated not in Italy but in Georgia. The world historical significance of the Georgian renaissance lies in the fact that it first shed light on the Western European Renaissance at the very time when almost all of the Western Europe was sunk into the medieval periphery; The Center for the Living of European Nations moved to Georgia where the sound of the new vital impulses of the world sounded at that time"- Miller-Budnitskaya 1976, 191).

The cultural paradigms of the "The Knight in the Panther's Skin,, in relation to the integrity of the world have been manifested many times, combining ancient western and eastern cultures. Everything is so natural, so organically intertwined that it is difficult to distinguish between the Western and Eastern realia. E.g., Shota Rustaveli writes: "Hey God, you one, you created everything, their faces and bodies". Here the main artistic feature of the God is "the One," that is, "God is one." The word God is mentioned in the poem for 193 times but the word "God" in the context of "Trinity" (Father, Son and Holy Ghost) is mentioned nowhere. It was the major charge against the poem that led its initial prosecution.

Revaz Siradze writes: "The human being is generally valued by human qualities, not by nationality or belief. The aestheticization of thinking has changed the notion of religion. Do we even think that the poet was aspiring to the idea of the world religion in his poem i.e. the world religion that would stand above all individual religions? (Siradze, $1982,207)$. Which religion would this be: Christianity, Judaism, Buddhism or Islam? Representatives of all religions will find the answer to this question, as their beliefs in the "The Knight in the Panthers Skin,, are protected by Shota Rustaveli.

Let's return to the concept of "ONE" in relation to God. The Poem "The Knight in the Panthers Skin“ is primarily a work of fiction, but one fact should be clearly outlined that Monophysitism in Georgia had been overcome four centuries before Rustaveli era. All the poets of Rustaveli's epoch emphasized the Saint Trinity hypothesis. We were expecting the same from Rustaveli, but that is not the case. How should this be explained? We think that the mixing of antique western and oriental thinking did not allow the poet to do so. The poet does not rely on the achievement of civilization of any universe, as he 
sees the eternity of the universe in the context of many civilizations. That is why he united everything in "ONE" phenomenon so that every person can find its originality and identity in it. It is an attempt to create the world culture where every nation retains its value and, at the same time, is the part of the world civilization. It is the way of thinking that has given a certain mark to our character, in particular, humanity and elastic nature. It might serve as the main reason for having so many foreign juveniles among us such as: Shushanik, St. Eustatius, St. Abo from the Georgian hagiography; as well Arab Avtandil, Indian Tariel whom we meet in the literary masterpiece. ... The readers' attention is attracted by the idealization of the Arab man in the poem. While Georgian history is rich with the facts when the Arabians were annihilating and destroying the Georgian statehood for a long period. How can these things be explained? The main thing here is the Georgian mentality which can be seen in the "The Knight in the Panthers Skin,,.

Avtandil, Tariel, Pridon represent different nationalities (in the artistic sense), but all three form a system of great cultural integrity. These different cultures are a sense of a united world that combines the values of each. One must feel humanity not in confrontation but in harmony. The key is the desire to create and spread love and kindness. Avtandil (one of the characters of the poem) was acting according to the same motives and the author writes about him that "Avtandil had the great desire for love.". Desire is the principal feeling of human which appears first in this world.

The time-space boundaries are not restricted in "The Knight in The Panther's Skin,.. People move freely. Their geographical map includes: Arabia, India, Khataei (China), Khwarazmi, etc. It is a unified cultural space. No one is going to be a hindrance to thoughtful movement. On the contrary, they happily meet, offer help, and support one another. Today, what the world has to do with Rustaveli is already decided.

Present world is a mingling of western and eastern values. Rustaveli was not afraid of either the East or the West. He knew that western world was the plastic manifestation of beauty, while the Eastern world was famous for its mysticism. He also knew that the Koran forbade painting, and Byzantine hymns were unanimous. He knew that the Bibleeducated Georgian scholars had been translating and getting acquainted with Ferdowsi's "Shahname", Fakhr-ed-Dingorgan's "Visramian". Such a fusion would greatly elevate the Georgian cultural landscape, but with the adoption of Christianity, it shifted to Western culture.

Everything connected with the concept "I am a person" should strive for the condition of behaving as a person. To be a person requires education, knowledge. This is the only way to make progress. A person is a bearer and novelty seeker. That's why a person has been in sharp antagonism with others ab origine. Salvation at such times is in the paradigms of world cultures, where every nationality brings its color to the world. This combination forms the basis of culturology: humanity without Homer, Cervantes, Shakespeare, Goethe, Rustaveli, Dostoevsky, Mozart, Bach, and Beethoven is unthinkable. What is the range of their contribution towards the humanity? Would anyone think that Shakespeare belongs to England alone?! -No! But when you tell an Englishman that Shakespeare is not an Englishman, you will be embarrassed. Yes, Shakespeare will never give up on being an Englishman, but he knows that he is at the same time a part of the world and that is exactly the cultural paradigm of globalization. The Georgian classical writer Shota Rustaveli is in the same condition.

Let's go back to the earlier term/concept "ONE" in relation to God. Why one and not three?! This was the era of poetry where the hypostasis of Trinity was not common but obligatory. The opinion of Ioane Petritsi is worth mentioning in this regard.

How can one serve as the combination of three segments and vice versa? Ioane Petritsi explains the unity of Saint Trinity amid the polyphony of the Georgian song. The Georgian song is the representation of all-in-one polyphony phenomenon consisting of 
three different voices which can be explained in the following way: The first voice, (in

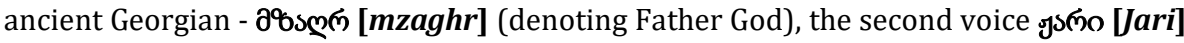
(Son of God) and the third voice $\mathbf{3} \boldsymbol{s} \partial$ [Bami] (Holy Spirit). Although the song is made up of three voices, it does not mean that the song has three different variations; it is one unique melody i.e. song. The same is true to the Saint Trinity and this is where its formula comes from: $1=3=1$.

In this world, everything is one. What we see around us is the face of something. Nothing that has no face is the invisible one, that is, the same God. This leads to the mystery. "At such times the pillar of humanity becomes beauty as the basis for the overthrow of opposition and the overthrow of the Almighty. One must seek God in his "I" who is experienced in spirit and flesh. Here the soul is Christian, the body is antique, and the two great worlds are reconciled."(Siradze, 1987, 128).

Literature is the service of an exalted and wonderful spirit. The soul is divine in man. His role is being close to God. Shota Rustaveli came close to God because his own concept related to "ONE" is given from the perspective of world cultures.

"The Knight in the Panther's Skin,, is a fight against one's own heart. An example of this is Tariel's combat with the tiger. Tariel loses his heart by killing himself, but fails to stand face to face with his own heart. According to Nana Gonjilashvili's observation: "Avtandil will bring Tariel's" heartless heart" to the world" (Gonjilashvili, 2016, 206).

Tariel, left with his own heart, would have done nothing if it had not been found next to him. The two hearts, which were then added to the hearts of others, filled the lost heart. Does Rustaveli tell us based on this episode (the story of the killing lions and tigers by Tariel), that resistance to multi-cultural unity can be overcome? The story tells us the friendship of two people belonging to different countries and cultures which means that the friendship has no boundaries. We strictly follow the idea. Soul, love, beauty, knowledge, culture, wisdom, goodness can't have any boundaries... These dignities belong to everyone. It belongs to the world. It would be difficult for Georgia otherwise ... it would be difficult for the world as well...

According to Ivane Javakhishvili, culture forms the basis of the "The Knight in the Panthers Skin,, which indicates to the diversity of cultural life. In the titles of the Georgian kings such as the king of Abkhaz, Kakha, Ranta, Armenian, Shirvan ... Georgia was not just called Georgia. It was the homeland of everyone. It was obvious that it had the ideological basis, but one should not forget that ideological unity was created by the culture of the countries enlisted in the titles of the Georgian kings. Such an ideology was the basis of Shota Rustaveli's thinking that cultural paradigms are the basis of world cultural studies. The poem "The Knight in the Panthers Skin" supports the idea of liberal thinking as well.

\section{References}

[1] Gonjilashvili N. (2016), The Word Illustrated, Tbilisi: Publisher Biblio

[2] Ingorokva P (2016), Rustvelological Studies, Volume IV, Tbilisi: Publisher "Chveni Mtserloba"

[3] Menabde L (Red) (1976), Rustaveli in World Literature, Volume I, Tbilisi: Tbilisi University Press

[4] Siradze R. (1987), Literary Aesthetic Essays, Tbilisi: Publisher. Nakaduli

[5] Siradze R. (1982), Theology, Tbilisi: Publisher "Nakaduli" 


\title{
PHILOLOGY
}

\section{ETYMOLOGICAL CLASSIFICATION OF TERMINOLOGY}

\author{
Damegul Seytova ${ }^{1}$
}

\section{Abstract}

This article discusses borrowed terms in English into which foreign-language word-formation tools penetrated, often reflecting word-formation norms of the language from which these words were borrowed.

Key words: borrowing, era, conquest, classification, semantic, era.

doi: http://doi.org/10.15350/F_7/12

Имеющиеся в словарном составе языка заимствованные термины можно: классифицировать: по источнику заимствования, по тому, какой аспект слова заимствован и по степени ассимиляции.

«В каждом языке немало слов из других языков» [1, с. 158]. Это можно вполне отнести и к заимствованным терминам. «..., других языках немало заимствований из русского языка, а также из разных других языков» [2, с. 159].

По источнику и эпохе заимствования в словарном составе английского языка различают: Кельтские заимствования.

Латинские заимствования первых веков нашей эры, т. е., попавшие еще до прихода англов и саксов на Британские острова (так паз. 1-й слой латинских заимствований). Латинские заимствования VI-VII вв., т.с. эпохи введения христианства в Англии (так паз. 2-й слой латинских заимствований).

Скандинавские заимствования эпохи скандинавских набегов (VIII-IX вв.) и особенно скандинавского завоевания (X в.). Старые французские заимствования (XII-XV вв.)»; обусловленные нормандским завоеванием.

Латинские заимствования XV-XVI вв. связанные с эпохой Возрождения (так наз. 3-й слой латинских заимствований). Новые французские заимствования после XVI в. Заимствования из греческого, итальянского, голландского, испанского, русского, немецкого и др. языков, обусловленные экономическими, политическими, культурными и т. д. связями с соответствующими народами.

Классификация по источнику заимствования разработала наиболее полно, но не является, как уже было указано, единственно возможной. Заимствования можно также классифицировать по тому, какой аспект слова оказывается новым для принимающего языка. По этому принципу заимствования подразделяются на фонетические, кальки (translation-loans), семантические и заимствования словообразовательных элементов.

Первый из названных типов, т.е. фонетические заимствования составляют основную и наиболее многочисленную группу. Они характеризуются тем, что общий звуковой комплекс их оказывается для заимствующего языка новым, хотя каждый из составляющих их звуков, за редкими исключениями, заменяется звуком языка, в который они попадают. Рассмотренные выше sport, labour, travel, people, -

\footnotetext{
${ }^{1}$ Damegul Seytova, Candidate of Phylological Sciences, Associate Professor, Karakalpak State University named after Berdq, Uzbekistan.
} 
castle, fortress и т.д. являются именно фонетическими заимствованиями.

Кальками называются заимствования в виде буквального перевода иностранного слова или выражения, т. е. точного воспроизведения его средствами принимающего языка с сохранением морфологической структуры и мотивировки.

Такими кальками являются, например, многие ставшие интернациональными заимствования из языка индейцев: pale-face бледнолицый, pipe of peace трубка мира. Много калек среди советизмов: palace of culture, house of rest, collective farm. Под семантическим заимствованием понимается заимствование нового значения часто переносного, к уже имеющемуся в языке термину. Семантические заимствования происходят особенно легко в близкородственных языках. Целый ряд примеров можно найти среди скандинавских заимствований. Так, например, др.англ. глагол dwell an блуждать, медлить, под влиянием др.-сканд. dvda жить, развился в современном английском в dwell жить. Таким образом в звуковом отношении dwell восходит к английскому, а в семантическом к скандинавскому глаголу. Случаев семантического заимствования среди существительных больше, чем среди глаголов. Существительное gift в др.-англ. означало не подарок, а выкуп за жену и затем, в результате ассоциации но смежности - свадьба. Скандинавский термин gift означало дар, подарок, и это отразилось на значении исконного термина. Из скандинавского получили свои современные значения термина: bread (в др.-англ. кусок ".' хлеба), dream (в др.-англ. радость), holm (в др.-англ. океан, море), plough (в др.-англ. мера земли). Заимствоваться может не только слово, но и отдельные значащие части термина. Морфемы заимствуются, конечно, не 'изолированно, а в терминах: если какие-нибудь иноязычные морфемы входят в большое число заимствованных терминов, то морфологическая структура этих терминов начинает осознаваться, а самые морфемы включаются в число словообразовательных средств принимающего языка. Многие греческие и латинские термины превратились в интернациональные префиксы. Например, anti-, counter-, inter-, sub-, ultra- и т. д.

Во всех языках широко употребительны греческие суффиксы; -ist, -ism, -isk. Далеко не все заимствованные слова ассимилируются так полно, как рассмотренные выше travel и sport. Поэтому по степени их ассимиляции заимствования можно подразделить на: полностью ассимилированные, т. е. соответствующие всем морфологическим, фонетическим и орфографическим нормам заимствовавшего языка и воспринимаемые говорящими как английские, а не иностранные nthvbys. Некоторые из них могут быть отнесены к основному словарному фонду: travel, street другие к прочей части словарного состава: operate, trail.

Частично ассимилированные, т. е. оставшиеся иностранными, по своему произношению, написанию или грамматическим формам:

analysis, 'pi. analyses, bacillus, pi. bacilli formula, pi. formulas \& formulae, bacterium, pi. bacteria boulevard ['bu: Invct], canal [ka'ricel], travail [trae'veil] restaurant ['rcstor D:ij], corps [ко:].

Эти термины часто отличаются неустойчивостью произношения: последний слог в слове restaurant произносится:

[п>:0], [то], [го:], [rag], [гол]

Частично ассимилированные и обозначающие понятия, связанные с другими странами и не имеющие английского эквивалента. Например:

Из русского: steppe, ruble, versta.

Из испанского: duenna, hidalgo, matador, real (монета).

К этой группе терминов относятся названия понятий, связанных с чужеземной национальной культурой, например, названия разных национальных одежд, жилищ, музыкальных инструментов, званий, профессий, утвари и т. д., и с чужеземной природой: т. е. названия животных, растении.

Особую группу составляют термины интернациональные. Нередко бывает, 
что обозначая важное новое понятие, слово заимствуется не в один какой-либо язык, а во многие языки. Таким образом создается международный фонд лексики, в который входит международная терминология различных областей человеческой деятельности: политики, философии, науки, техники, искусства, а также многие абстрактные термины.

Интернациональные, или международные термины, заимствованные из одного источника, имеют графическое и звуковое сходство и, совпадая до некоторой степени по смыслу, составляют как бы общее достояние ряда языков. Большая часть их является результатом параллельного обогащения новых языков за счет лексики древних, т.е. латинского и греческого (democracy, proletarian, philosophy, atom, satellite, synonym, rhythm). Другая часть их идет из современных языков: soviet, kolkhoz, sputnik - из русского, revolution, bourgeois - из французского, sonata, soprano, violoncello - из итальянского. К интернациональным терминам не относятся родственные соответствия, т. е. термины, наличие которых в ряде языков является следствием родства этих языков и их происхождения от одного языка - основы: англ. mother нем. Mutter русск. Мать англ. поsенем. Nasсрусск. нос англ. goose нем. Hanspyсcк. Гусь Интернациональные термины представляют большой методический интерес в практике преподавания и требует к себе особого внимания и особого подхода.С одной стороны, преподаватель обязан, чтобы облегчить их понимание и запоминание использовать сходство между терминами в родном и; изучаемом языке, в частности сходство графики, которая может доходить до полного совпадения. С другой стороны, преподаватель обязан показать национальное своеобразие оформления и значения интернациональных терминов в английском языке. Важно обратить внимание учащихся на различия между ними не только в их внешней форме: индустрия, industry, но и в значении. Например, слово control в английском языке многозначно, и основные его значения там не контроль, а управление, руководство, власть. Английское family значит только семья. или род, значения фамилия не имеет никогда. General, как существительное однозначной совпадает по значению с русским генерал, но гораздо чаще встречается прилагательное general - это последнее полисемантично: общий, главный, обычный и т. д. Русская «индустрия» употребляется гораздо реже, чем его синоним «промышленность» и уже поэтому не совсем эквивалентно английскому «industry». Кроме того, последнее имеет еще значение трудолюбие, прилежание и поэтому часто вызывает затруднение при переводе. Термин magazine в английском языке имеет два значения; журнал и склад военных' Припасов, ни одно из которых не соответствует русскому - магазин. Существительное original и русское оригинал совпадают во всех своих значениях. Но original имеет омоним - прилагательное, у которого значение оригинальный будет второстепенным, а основным значением - первоначальный, подлинный.

Причиной расхождения в значении является прежде всего то обстоятельство, что, как уже говорилось выше, слово, многозначное в том языке, откуда оно заимствуется, в заимствующий язык нередко попадает только в одном из своих значении, чаще всего в специальном. Сравн. англ. out и русское аут (в спорте). Бывают такие случаи, когда интернациональные термины, совпадающие в прямом значении, расходятся в возможностях переносного употребления. Термин атом и русском языке не употребляется с переносным значением малютка, крошка, как это иногда имеет место в английском.

\section{References}

[1] И.А.Фигуровский.Введение в общее языкознание.Изд. «Просвещение». М., 1969.

[2] Там же. 


\title{
ADVERTISING DISCOURSE IN LINGUISTICS
}

\author{
Umida Mahmudova ${ }^{1}$
}

\begin{abstract}
This article examines the nature of discourse of advertising in linguistics. This article focuses on the interaction of language with advertising, its image and layout, and examines advertising persuasive strategies. It discusses main interrelationship between culture and advertising discourse. This study is not meant to exhaust all the fields of the particular discourse and does not involve to all the problems it poses. This article aims at find the basic elements of the most influential discourse of the $21^{\text {st }}$ century advertising text.
\end{abstract}

Key words: advertising, text, discourse, culture, linguistics, semiotics.

doi: http://doi.org/10.15350/F_7/13

Developing marketing strategies to protect the local market and active access to foreign market in the context of globalization is one of the most pressing challenges of today. In the beginning, it is important to define advertising itself. What is advertising? Advertising is an extremely multifaceted phenomenon. The term comes from the Latin word to the advertiser to shout loudly or to notify, which reflects the original function of advertising - information are shouted out or read out in squares and in other places where people gather, advertising always carries information, however, if advertising is always information, information not always an advertisement. In fact, advertising is special information that is distributed in accordance with the law by any legal or natural person, products, including trademarks, service marks and technologies for the purpose of direct or indirect profit [1]. The history of advertising technology has evolved from mass advertising to divide the consumer audience into the so-called target groups. Linguistic study of advertising is the types of the text in advertisement, its description in terms of the basic paradigm "Text is a discourse." The concept of "discourse" has acquired an extraordinary popular in modern linguistics. Van Dijk remarks advertising discourse: "often the most vague and difficult to define concepts become the most popular. Discourse is one of them." According to Goddard, "discourse advertising is a way through which people construct their ideas about the world" [2]. There might be different types of words in advertising text but they do not happen in isolation they occur in complex interaction with music, picture, jingles and other text around them [3]. There are a lot of purposes for using language which determine how the writer or speaker chooses words and how they use figurative language. The language has a very powerful effect over people their thought and actions. The aim of this work is to consider the modern understanding of discourse from the point of view of the basic paradigm "text - discourse" and features of the advertising language in the context of discursive analysis. Despite the large number of works on various text issues - recognized communicative unit, there is no single universally accepted definition of the concept of "text", which apparently due to the great complexity and versatility of the object. It is indicated that the process of speech itself (oral or written) leads to the generation of a text - speech product, message developing in a sequential description of a number situations. Definition of discourse in different linguistic sources ambiguous that shows a different attitude of linguists belonging to different linguistic schools to this concept. In Uzbek linguistics, the term discourse is used in more broadly. We consider the

\footnotetext{
${ }^{1}$ Umida Mahmudova, PhD student of Karshi state university, Uzbekistan.
} 
discourse as a coherent text in conjunction with extralinguistic, sociocultural, psychological and other factors. Discourse is a dynamic process, reflects to the functional features of the speech and has an expressive and cognitive properties. It's important for the advertising language to distinguish oral and written discourses. Oral discourse allows for great lexical and grammatical variation, at the same time plays an important role. Many phenomena considered to be part of oral discourse, fixed in many dictionaries and became the main part written discourse. These phenomena can be understood based on context in linguistic and extralinguistic. The use of punctuation in writing, as well as in oral speech which determines the rhythm speech, and its perception of reading and listening. Advertising texts constitute a discourse. They are always dynamic and modern, they are perceived by the participants of communication in the context. In many advertising texts, with verbal elements include audiovisual. These items may belong to different topics and do not have a clear structure. Texts in the structuring of which, in addition to verbal means, iconic (picture, drawing, photograph) are used, as well as other means semiotic codes (such as color, font, size), called creolized. Their texture consists of two homogeneous parts: verbal (language / speech) and non-verbal (belonging to other sign systems than natural language). As a rule, the presence of a non-verbal component is perceived as an indispensable attribute of a full-fledged advertising text. The text is seen as a reflection. Under advertising text means the totality audiovisual media in arbitrary combinations (with the permissible absence of any element) aimed at the recipient in order to provide the planned impact directly or indirectly associated with object of advertising. Mandatory minimum element of the advertising text - the word / digital number / abbreviation or symbol, when decoding outputting the object of impact on the addressee. Studies about the discourse of advertising with a linguistic focus remain rare.

Conclusion. In conclusion, summarizes result of the proposed. The final phrase the slogan - should encourage the buyer to take action ("buy today", "call now", etc.). This is the most strong form of trading offer. In coming up with a slogan, you need to strive for to ensure that it is consistent with the overall advertising theme, is concise, formulated by original pun and contained, by opportunities, company name. When creating advertising text, authors use the entire arsenal of linguistic and non-linguistic means in order to find the most effective form of influence on the addressee. As a type of spoken media, advertisements can be one of the most crucial media discourses in terms of manipulated language use and hidden ideologies.

\section{References}

[1] Law of the Republic of Uzbekistan "On Advertising" Article 4

[2] Goddard, A. (1998). The language of advertising. London \& New York. Routledge.

[3] Cook, G. (1992). Discourse of advertising. London and New York: Routledge. 


\title{
PEDAGOGY AND PSYCHOLOGY
}

\section{INVESTIGATION OF DYNAMICS OF PRIMARY SCHOOL PUPILS' SENSE OF LANGUAGE}

\author{
Aghababyan Karine ${ }^{1}$
}

\begin{abstract}
The dynamics of primary school pupils' sense of language (SL) is investigated by using of the word associative experiment method. It is proposed the complex of multistage methodic to increase the level of school students' SL. One cycle consists of four stages: preliminary determination of the level of SL, differentiated training, testing by varying complexity tests and re-determination of the level of SL.
\end{abstract}

Key words: sense of language, word associative experiment method, rating factor.

doi: http://doi.org/10.15350/F_7/14

Развитие «чувства языка» (ЧЯ) учащихся в процессе обучения является одним из основных путей совершенствования навыков владения родным языком. Формирование ЧЯ - сложный психолингвистический процесс, сплетенный осознанно-логическими $[1,2]$ и интуитивно-подсознательными $[3,4]$ элементами словестного восприятия мира, который обеспечивает формирование коммуникативной компетенции индивида и способствует ее развитию $[4,5]$.

Предлагаемая технология развития ЧЯ учащихся в процессе их обучения можно представить схемой, приведенной на Рис. 1. На первом этапе методом свободного словестного ассоциативного эксперимента (ССАЭ) [6,7] определяется начальный уровень ЧЯ школьников, по результатам которого формируются группы учащихся и определяются рейтинги каждой группы [5]. На втором этапе проводится одномесячное дифференцированное обучение по специально разработанным методикам с последующей проверкой знаний по тестам трехуровневой сложности (третий этап). На четвертом этапе методом ССАЭ проводится повторное определение уровня ЧЯ учащихся, по результатам которого оценивается эффективность примененных методик обучения для каждого школьника и заново формируются группы с целью повторения цикла 2-3-4-2 (Рис.1). Цикл 2-3-4-2 можно повторить, исходя из достижения желаемой величины уровня чЯ учащихся. При этом следует отметить, что в любом случае рост уровня ЧЯ школьников приходит к насыщению, ибо он, очевидно, ограничен уровнем ЧЯ обучающего учителя. ${ }^{2}$

\footnotetext{
${ }^{1}$ Karine Aghababyan, Candidate of Pedagogical Sciences, Associate Professor, Armenian State Pedagogical University, Armenia.

${ }^{2}$ Аналогичную методику можно применить с целью повышения уровня ЧЯ будущих учителей во время их магистерсокого обучения в педагогических ВУЗ-ах [8] или во время переподготовки действующих учителей.
} 


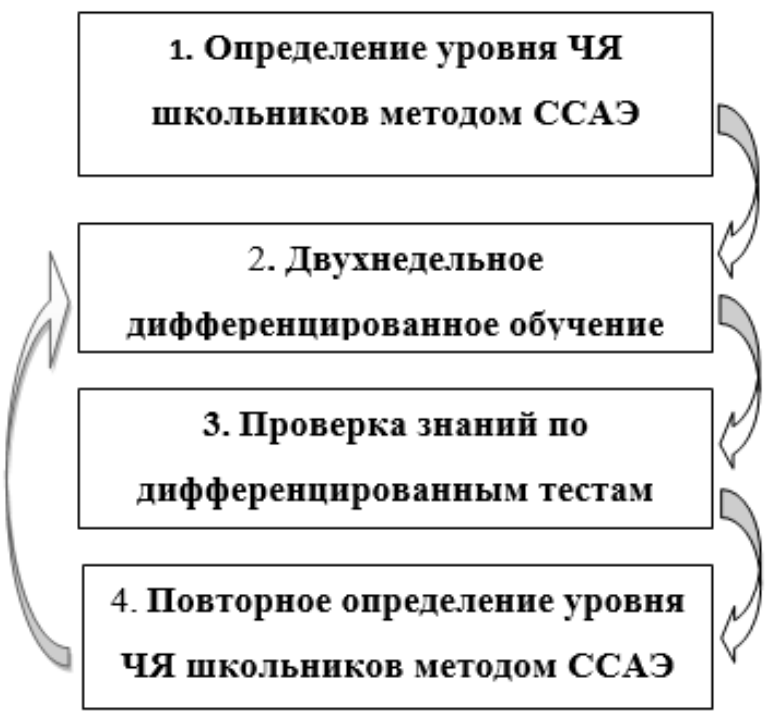

Рис. 1. Схема исследования ЧЯ школьников

В настоящей статье приведены результаты исследования динамики развития ЧЯ учащихся 4-ого класса после одного технологического цикла (Рис. 1). В качестве респондентов были выбраны 14 учеников четвертого класса. Объектом исследования являлись базовые составляющие ценностной системы, лежайщей в основе формирования личности: отчизна, искусство, природа, семья, образование. Для каждого из них выбраны по пять слов-стимулов (табл.3), а шестое - выбрано произвольно, с целью минимизации возможности образования логических цепочек. Слова-стимулы диктовались в разупорядоченном порядке. При этом участники не были заранее ознакомлены с целями проведения эксперимента: им было предложено в течениие 5-7 сек. на заранее приготовленных бланках перед номером продиктованного слова-стимула записать первое пришедшее на ум слово или словосочетание. При анализе результатов и количественной оценки учитывались первые слова-реакции. Оценка проводилась по четырехбалльной системе: наивысшим баллом оценивались наиболее глубинные слова-реакции (мать - святой, omчизна); более поверхностные, типичные ответы получали 3 балла (мать - родной человек, радость); слова-реакции, являющиеся синонимами или антонимами словстимулов, получали 2 балла (мать - мачеха, умиротворение); слова-реакции, являющиеся грамматической формой или простейшим смысловым продолжением слов-стимулов, получали 1 балл (мать - отец, бабушка). 
Таблица 1

Формирование групп по результатам ССАЭ

\begin{tabular}{|c|c|c|c|c|c|c|}
\hline \multirow{2}{*}{ 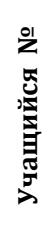 } & \multicolumn{2}{|c|}{ Первое ССАЭ } & \multirow{2}{*}{ 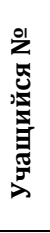 } & \multicolumn{2}{|c|}{ Второе ССАЭ } & \multirow{2}{*}{ 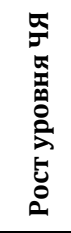 } \\
\hline & $\begin{array}{c}\text { Оценка } \\
\text { слов- } \\
\text { реакций } \\
\end{array}$ & $\begin{array}{c}\text { Рейтинг группы } \\
\text { (максимальное } \\
\text { значение) } \\
\end{array}$ & & $\begin{array}{c}\text { Оценка } \\
\text { слов- } \\
\text { реакций } \\
\end{array}$ & $\begin{array}{c}\text { Рейтинг группы } \\
\text { (максимальное } \\
\text { значение) } \\
\end{array}$ & \\
\hline 1 & 18 & \multirow{3}{*}{$\begin{array}{c}0.211 \\
(0.287)\end{array}$} & 1 & 21 & \multirow{3}{*}{$\begin{array}{c}0.264 \\
(0.400)\end{array}$} & \multirow{3}{*}{0.053} \\
\hline 2 & 34 & & 3 & 47 & & \\
\hline 3 & 34 & & 2 & 52 & & \\
\hline 4 & 41 & \multirow{3}{*}{$\begin{array}{c}0.414 \\
(0.423)\end{array}$} & 4 & 57 & \multirow{3}{*}{$\begin{array}{c}0.578 \\
(0.603)\end{array}$} & \multirow{3}{*}{0.164} \\
\hline 5 & 43 & & 6 & 61 & & \\
\hline 6 & 43 & & 7 & 63 & & \\
\hline 7 & 46 & \multirow{3}{*}{$\begin{array}{c}0.456 \\
(0.470)\end{array}$} & 5 & 67 & \multirow{3}{*}{$\begin{array}{c}0.669 \\
(0.673)\end{array}$} & \multirow{3}{*}{0.213} \\
\hline 8 & 46 & & 8 & 67 & & \\
\hline 9 & 49 & & 12 & 68 & & \\
\hline 10 & 52 & \multirow{4}{*}{$\begin{array}{c}0.525 \\
(0.543)\end{array}$} & 9 & 71 & \multirow{4}{*}{$\begin{array}{c}0.710 \\
(0.740)\end{array}$} & \multirow{4}{*}{0.185} \\
\hline 11 & 53 & & 11 & 71 & & \\
\hline 12 & 56 & & 10 & 77 & & \\
\hline 13 & 56 & & 13 & 77 & & \\
\hline
\end{tabular}

Суммарные баллы каждого респондента приведены в табл.1. По набранным баллам были образованы группы: в первую группу вошли студенты, набравшие до 35; во вторую - от 41 до 45; в третью - от 46 до 50, в четвертую - от 51 до 60.1 Далее определялся рейтинг группы по формуле [5]

$$
\delta_{j}=\left(M \zeta_{j}-\sqrt{D \zeta_{j}}\right) / 100
$$

где $\zeta_{j}: S_{1}, S_{2}, \ldots, S_{\tau_{j}}$ случайная величина, определенная на множестве суммарных баллов респондентов группы $\mathbf{j}, M \zeta_{j}=\frac{1}{\tau_{j}} \sum_{i=1}^{\tau_{j}} s_{i}$ - математическое ожидание и $D \zeta_{j}=\frac{1}{\tau_{j}} \sum_{i=1}^{\tau_{j}} s_{i}^{2}-\left(M \zeta_{i}\right)^{2}-$ дисперсия случайной величины $\zeta_{j}, \tau_{j}$ - число учеников в ј-ой группе. Отметим, что максимальное значение рейтинга группы, $\delta_{\mathrm{j}}^{\max }=\mathrm{M} \zeta_{l} / 100$, достигается при нулевом значении дисперсии, т.е. при $D \zeta_{j}=0 \cdot^{2}$ Очевидно, близость значения рейтинга группы к $\delta_{\mathrm{j}}^{\max }$ обеспечивает степень достоверности информации об уровне Чя каждого члена данной группы. Именно по этой причине в одну и ту же группу следует включать респондентов, получивших

${ }^{1}$ Отметим, что выбор интервалов набранных баллов несколько произволен и может быть изменен в зависимости от конкретной ситуации. Важно лишь то, чтобы в одну и туже группу были вовлечены ученики с близким уровнем ЧЯ и чтобы группа содержала не менее трех и не более пяти членов.

2 В этом случае набранные балы каждого члена группы равны. 
максимально близкие баллы. В табл.1 указаны группы респондентов, образованные после первого ССАЭ, приведены текущие и максимальные (в скобках) значения рейтингов соответствующих групп.

Отметим, что двухнедельные занятия проводились совместно со всеми учениками по единой программе и методикам (сами ученики не были уведомлены об их принадлежности к той или иной группе).

После двухнедельных занятий проверка проводилась по заданиям трехуровневой степени сложности (в зависимости от рейтинга группы). При этом в процессе оценивания групповой работы наряду с преподавателем участвовали как ученики других групп (оценивание презентаций, эссе и т.п.), так и сама экзаменуемая группа (самооценка). Окончательная рейтинговая оценка группы формировалась умножением текущей оценки групповой работы на рейтинг данной группы (Табл.2).

Таблица 2

Методика оценивания групповой работы

\begin{tabular}{|c|c|c|c|c|c|}
\hline \multirow[b]{2}{*}{ 畓 } & \multicolumn{4}{|c|}{ Формирование оценки групповой работы } & \multirow[b]{2}{*}{$\begin{array}{c}\text { Рейтинговая } \\
\text { оценка } \\
\delta \times \alpha\end{array}$} \\
\hline & $\begin{array}{c}\text { Оценка } \\
\text { учителя } \\
(1-5) \text { балл }\end{array}$ & $\begin{array}{c}\text { Самооценка } \\
\text { (1-2) балл }\end{array}$ & $\begin{array}{c}\text { Оценка других } \\
\text { групп } \\
\text { (1-3) балл }\end{array}$ & $\begin{array}{c}\text { Окончательная } \\
\text { оценка } \\
\alpha\end{array}$ & \\
\hline I & 3 & 2 & $(222), \quad 2$ & 7 & 1.477 \\
\hline II & 4 & 2 & $(233), \quad 2.7$ & 8.7 & 3.602 \\
\hline III & 3 & 2 & $(323), \quad 2.7$ & 7.8 & 3.557 \\
\hline IV & 3 & 1 & (222), & 6 & 3.150 \\
\hline
\end{tabular}

С целью определения эффективности использованных методик обучения, был проведен повторный САЭ по тем же стимулам-словам, но продиктованным в иной последовательности. Результаты анализа второго САЭ: суммарные балы респендентов, реорганизованные группы, рассчитанные и максимальные значения рейтингов групп приведены в Табл.1. Видно, что все ученики получили более высокие баллы, что и привело к повышению рейтинга некоторых групп, приближая их к максимальному значению. Однако поскольку после второго ССАЭ происходит перераспределение учеников по группам, то, очевидно, что рейтинги некоторых групп могут понизиться. Однако, в любом случае, максимальное значение рейтингов групп растет, что свидетельствует о росте уровня ЧЯ каждого отдельного респондента (табл. 1).

Сравнение рейтинговых коэффициентов, определенных по результатам двух ССАЭ (Табл.1), показывает, что рейтинги групп увеличились, приближаясь к своему максимальному значению. Это, с одной стороны, свидетельствует об эффективности методик проведенных групповых работ, с другой стороны, показывает, что уровени ЧЯ как каждого отдельного ученика, так и групп учеников имеют положительную динамику роста. 
Таблица 3

Формирование групп по результатам ССАЭ

\begin{tabular}{|c|c|c|c|c|c|c|}
\hline \multirow[b]{2}{*}{ 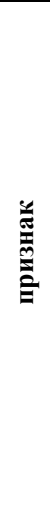 } & \multirow[b]{2}{*}{ Слово-стимул } & \multicolumn{2}{|c|}{ Первый ССАЭ } & \multicolumn{2}{|c|}{ ВТорой ССАЭ } & \multirow[b]{2}{*}{ 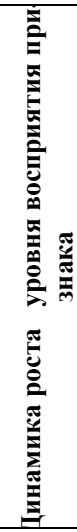 } \\
\hline & & 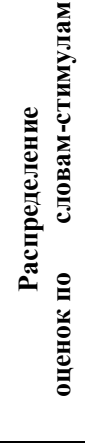 & 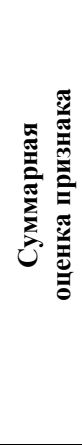 & 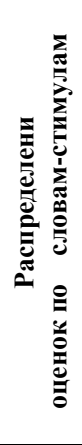 & 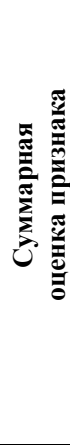 & \\
\hline 1 & 2 & 3 & 4 & 5 & 6 & 7 \\
\hline \multirow{5}{*}{ 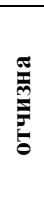 } & родина & 28 & \multirow{5}{*}{ 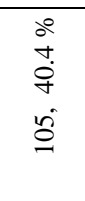 } & 35 & \multirow{5}{*}{$\begin{array}{l}\stackrel{\circ}{ } \\
\text { in } \\
\text { ñ }\end{array}$} & \multirow{5}{*}{$\begin{array}{l}00 \\
n \\
n \\
\tilde{n} \\
\text { ñ }\end{array}$} \\
\hline & развитие & 13 & & 24 & & \\
\hline & воля & 15 & & 25 & & \\
\hline & религия & 25 & & 25 & & \\
\hline & сила & 24 & & 28 & & \\
\hline \multirow{5}{*}{$\sum_{\bar{E}}^{\bar{E}}$} & мать & 42 & \multirow{5}{*}{ 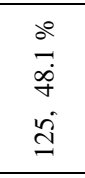 } & 44 & \multirow{5}{*}{ 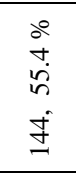 } & \multirow{5}{*}{ 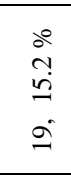 } \\
\hline & дом & 24 & & 25 & & \\
\hline & деньги & 17 & & 19 & & \\
\hline & очаг & 21 & & 29 & & \\
\hline & ребенок & 21 & & 27 & & \\
\hline \multirow{5}{*}{ 竞 } & Земля & 28 & \multirow{5}{*}{$\begin{array}{l}0 \\
n \\
o \\
+ \\
i \\
i\end{array}$} & 26 & \multirow{5}{*}{$\begin{array}{l}\infty \\
\infty \\
n \\
n \\
\dot{y} \\
\dot{y}\end{array}$} & \multirow{5}{*}{$\begin{array}{l}\stackrel{0}{0} \\
\infty \\
\stackrel{a}{0} \\
\dot{d}\end{array}$} \\
\hline & пейзаж & 20 & & 24 & & \\
\hline & защитник & 32 & & 37 & & \\
\hline & Солнце & 23 & & 34 & & \\
\hline & лес & 18 & & 24 & & \\
\hline \multirow{5}{*}{ 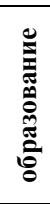 } & школа & 27 & \multirow{5}{*}{$\begin{array}{l}d \\
\dot{v} \\
\ddot{n} \\
\text { à }\end{array}$} & 31 & & \multirow{5}{*}{$\begin{array}{l}00 \\
0 \\
\text { i } \\
m \\
0 \\
0\end{array}$} \\
\hline & книга & 19 & & 26 & so & \\
\hline & знание & 18 & & 25 & 定 & \\
\hline & учеба & 11 & & 16 & กี & \\
\hline & должность & 17 & & 24 & & \\
\hline \multirow{5}{*}{ 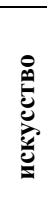 } & театр & 19 & \multirow{5}{*}{$\begin{array}{l}\delta^{0} \\
\dot{t} \\
\ddot{g} \\
\infty \\
= \\
=\end{array}$} & 26 & & \multirow{5}{*}{ 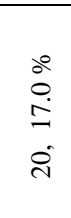 } \\
\hline & религия & 25 & & 25 & 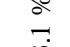 & \\
\hline & любовь & 31 & & 35 & $\sigma$ & \\
\hline & человек & 22 & & 27 & $\stackrel{\infty}{\infty}$ & \\
\hline & достижение & 21 & & 25 & & \\
\hline
\end{tabular}

В то же время, данные Табл.3 показывают, что суммарные оценки каждой группы по отдельным признакам также растут, что свидельствует о развитии более глубинного словесного восприятия основных ценностных понятий. При этом у групп с изначально более низким рейтиговым показателем динамика роста более 
высока. Это вполне резонно, поскольку рост уровня ЧЯ ограничен и при всех прочих равных условиях стремится к насыщению - к максимально возможному (при фиксированных условия) уровню.

Таким образом, полученные результаты попоказывают, что предлагаемая комплексная методика перманентного развития чЯ учеников начальной школы является эффективной. При этом циклическая повторяемость взаимосвязанных самосогласованных этапов воздействия обеспечивает устойчивую динамику непрерывного роста уровня чЯ каждого ученика.

References

[1] Kainz F. Psychologie der Sprache. Stuttgart, 1941. Bd. 1,3. Aufl., 1965. p. 186.

[2] Gokhlerner M.M., Ejger G.V. Psikhologicheskij mekhanizm chuvstva yazyka. Voprosy psikhologii, 1983. №4. s. 137.

[3] Vasil'eva V.F. «Yazykovoe myshlenie» i «vnutrennie zakony» yazyka. Yazyk, soznanie, kommunikatsiya: sb. statej. M.: MAKS pres, 2009. № 38. s. 89.

[4] Bozhovich E.D. Uchitelyu o yazykovoj kompetentsii rebenka. Psikhologopedagogicheskie aspekty yazykovogo obrazovaniya. M.: MPSI, 2002. $278 \mathrm{~s}$.

[5] Aghababyan К. Н. Актуальные научные исследования в современном мире, 2018, № 9(41), часть 3 , с. 87

[6] Deese J. The structure of associations in language and thought. Baltimore, J. Hopkins press, 1966. p. 216.

[7] Apresyan Yu.D. Idei i metody sovremennoj strukturnoj lingvistiki. M.: Nauka, 1996, 305 s.

[8] Aghababyan K. H. Humanities in the $21^{\text {st }}$ century: scientific problems and 54 searching for effective humanist technologies, Pedagogical sciences, 2016, San Francisco, USA, p. 55. 


\section{TYPOLOGY OF SOCIAL STEREOTYPES}

\section{Zhumaev Ulugbel ${ }^{1}$}

\section{Abstract}

A stereotype is an adaptive reaction of an organism to situations repeating many times. The social stereotype arises in the process of joint, stable, repetitive activity of people and ensures its reproduction, expressed in the usual actions, rules, norms, traditions, customs of public life. The social stereotype expresses the typical, enshrined in the consciousness and actions of a person attitude towards the km-shaped phenomena of public life, other people and their communities. It accumulates the previous experience of the individual and various social groups, which has developed under the influence of socio-historical conditions, other components of the social environment in a kind of algorithm of attitude to the corresponding object. Stereotypes characterize the development of consciousness in its various manifestations, at any level (individual, group and mass, scientific and ordinary, as well as extra-scientific and anti-scientific). In each of these cases, stereotypes have their own characteristics. The more knowledge is developed and the rationale for the relationships of the real world fixed in it is developed, the wider, more mobile, more flexible are the generalized and stable forms underlying it. Conversely, the narrowness and superficiality of consciousness are the basis for the narrowness and abstractness of its stereotypes and, at the same time, commitment to them.

Key words: psychology, personality, behavior.

doi: http://doi.org/10.15350/F_7/15

Стереотип - это приспособительная реакция организма к ситуациям, повторяющимся множество раз. Социальный стереотип возникает в процессе совместной, устойчивой, повторяющейся деятельности людей и обеспечивает ее воспроизводство, выражаясь в привычно выполняемых действиях, правилах, нормах, традициях, обычаях общественной жизни. Социальный стереотип выражает типичное, закрепленное в сознании и поступках человека отношение к многообразным явлениям общественной жизни, другим людям и их общностям. Он аккумулирует предшествующий опыт индивида и различных социальных групп, сложившийся под влиянием социально-исторических условий, других компонентов социальной среды в своеобразный алгоритм отношения к соответствующему объекту. Стереотипы характеризуют развитие сознания в разных его проявлениях, на любом уровне (индивидуальном, групповом и массовом, научном и обыденном, равно как и вненаучном и антинаучном). В каждом из этих случаев стереотипы имеют свои особенности. Чем больше развито знание и развернуто обоснование фиксируемых в нем отношений реального мира, тем шире, подвижнее, гибче лежащие в его основе обобщенные и устойчивые формы. И наоборот, узость и поверхностность сознания являются базой для узости и абстрактности его стереотипов и в то же время приверженности к ним.

Чтобы уяснить особенности и характер действия стереотипов в различных условиях, необходимо прежде всего учесть многообразие их форм. Попытка клас-

\footnotetext{
${ }^{1}$ Zhumaev Ulugbel, Candidate of Psychological Sciences, Associate Professor, Bukhara State University, Uzbekistan.
} 
сификации стереотипов была предпринята Л.Гусляковой, она выделила пять оснований для типологии. На наш взгляд, данная классификация может быть уточнена дополнена. В результате такой аналитической работы выделяются следующие логические основания.

1.Направленность, или степень адекватности стереотипов. В соответствии с этим можно говорить об истинных или ложных стереотипах («положительных», «отрицательных»). К «положительным» можно отнести облегчение возможности быстро ориентироваться в окружающей действительности, обретение способности к обобщению, синтезу, концентрации внимания. В основе формирования таких стереотипов лежит здравый смысл. «Отрицательные» обусловливают большую степень консервативности (условия меняются, а стереотипы остаются прежними), упрощают подходы к оценке тех или иных явлений, людей (примерами могут служить всевозможные предрассудки).

Вопрос об адекватности стереотипов имеет свою историю. Одной из характерных черт ранних исследований, посвященных стереотипам, является то, что к ним относились лишь как к неадекватным обобщениям. В дальнейшем в результате многих экспериментальных исследований было показано, что стереотипы могут быть как неадекватными, так и адекватными. Для проверки стереотипов на адекватность в основном использовался анкетный метод и изучение определенных документальных материалов. Взгляды различных авторов на проблему адекватности стереотипов не раз анализировались в литературе (А.А.Бодалев, П.Н.Шихирев, Г.Оллпорт и др.).

2.Субъект формирования стереотипов. Одни из них складываются бессубъектно, или стихийно, в зависимости от индивидуального опыта, от разнообразных случайных переплетений его с опытом общественным. Такие стереотипы в достаточной мере устойчивы в самых различных условиях, они сходны в целом с чувствами симпатии и антипатии. Они часто могут быть узколичностными и, наоборот, весьма широкими, и в то же время нейтральными, связанными больше всего с традицией, обоснование которой скрыто временем и давним происхождением.

Другие стереотипы формируются сознательно в результате воздействия различных факторов: идеологических, культурных, национальных и др. Они имеют достаточно четкую направленность, которая в случае реакционности идеи может быть вполне искусно завуалирована. Стереотипы «приживаются» в том случае, если субъектом учитывается специфика и природа уже имеющихся стереотипов. Существуют ситуации, когда стихийно сформированные стереотипы, например национальные предубеждения, сложившиеся на основе воспитания и общения семье или группе, подвергаются целенаправленному воздействию и превращаются в националистические предрассудки. В результате стереотипы могут быть и разнонаправленными, если они возникают под воздействием различных систем идей (например, в обществе сталкиваются враждебные друг другу мировоззрения различных классов).

3.Объект стереотипизации. Стереотипы могут быть направлены как на отдельного человека, так и на представителей каких-то определенных социальных групп или просто на массу людей. Следовательно, можно говорить об индивидуальных, групповых и массовых стереотипах. Первые формируются в ходе неповторимого житейского опыта под влиянием самых разнообразных, порой совершенно случайных факторов. Они способны принимать весьма причудливую форму и выступать в качестве различного рода предубеждений, распространяясь на любые явления и процессы, реализуясь через установки, выражаясь в привычках. Чаще всего они носят нейтральный характер в том смысле, что в них проявляется лишь инди- 
видуальный опыт, лишенный окраски классовых, национальных и других социальных особенностей. Но они способны и усиливаться под воздействием других сознательно вносимых стереотипов, которые, в свою очередь, придают им определенную направленность.

Групповыми стереотипами можно назвать те закрепившиеся в сознании и повторяющиеся образы, которые разделяются и воспроизводятся любым членом какой-либо социально организованной группы. Например, различные национальные стереотипы или профессиональные стереотипы, своеобразие которых определяется спецификой трудовой деятельности, не принятой в другой социальной группе. К ним относятся и классовые стереотипы, определяющиеся местом данного класса системе производства того или иного общества. Особый интерес представляют массовые стереотипы. Они могут принадлежать представителям любого класса, любой национальности. Формы их проявления различны, они существуют даже в том случае, когда толпа анонимна.

4.Сфера проявления стереотипов. Можно выделить стереотипы мышления (через стереотипы-образы и стереотипы оценки) и поведения. Стереотипы образы порой могут выступать в виде идеологических построений, через которые в сознание личности, группы, общества в целом вносится чаще всего предвзятое отношение к различным социальным, политическим, экономическим или другим явлениям, процессам, лидерам, странам (например, стереотипы восприятия таких образов, как «враг народа», «железный занавес», «свободный мир», «свободный рынок» и др.). Стереотип поведения - это система поведенческих навыков, передаваемых из поколения в поколение путем сигнальной наследственности, специфичная для каждого социального коллектива, общности. Стереотип поведения складывается процессе адаптации к окружающей среде. Собственный стереотип поведения воспринимается членами определенной социальной общности как единственно возможный, нормальный стандарт взаимоотношений, образа жизни и действия людей.

5.Степень изменчивости стереотипов. В одних случаях они могут быть стабильными, консервативными, в других - подвижными. А.В.Меренков указывает, что устойчивость социальных стереотипов определяется двумя факторами. 1) соответствием стереотипа условиям жизнедеятельности конкретного индивида (или группы). Чем чаще его использование приводит к дисфункциональным последствиям, тем интенсивнее он будет изменяться, то есть здесь подчеркивается фактор личностного, индивидуального опыта. 2) временем возникновения: чем старше культурные традиции использования данного стереотипа, чем раньше он возник, тем труднее будет происходить процесс трансформации. Здесь выделяется социокультурный фактор, влияние общества на индивида.

6.Характер осмысления действительности и взаимодействия с ней позволяет выделить три вида стереотипов: восприятия, осмысления информации и практического действия. Стереотипы восприятия представляют собой программу первичной обработки тех сигналов внешней действительности, которые воздействуют на органы чувств. Они создают некую модель, на основе которой происходит сравнение запечатленного образа с тем, что человек получает во всех последующих случаях. Тем самым стереотипы восприятия позволяют очень быстро выделить известные предметы среди многообразия внешнего мира и сформировать готовность для оперирования ими. Стереотип осмысления действительности представляет собой наиболее сложный вид оперирования устойчивыми программами анализа, поскольку приходится постоянно выделять самые существенные характеристики предмета познания и соединять их в определенном порядке. Они, в свою 
очередь, определяют содержание и направленность будущего стереотипа практической преобразовательной деятельности.

7.Функциональное значение стереотипов. Здесь можно выделить созидательные и разрушительные. Это стереотипы, в которых заложена созидательная или разрушительная модель поведения. Одни формируют определенную программу действий соответственно принятым и поддерживающим целостность группы представлениям и образам; другие, напротив, разрушают ее.

8.Содержание стереотипов позволяет разделить их на две категории: стереотипы, характеризующие людей как членов определенных групn (национальных, социальных, политических), и стереотипы, характеризующие личностные особенности людей по их поведению, физическим качествам, оформлению внешности и т. д. В настоящее время изучены такие виды стереотипов, как национальные, этнические, ролевые, гендерные, возрастные, статусные и некоторые другие.

По мнению всех изучающих стереотипы, главной их характеристикой является то, что они связаны с процессами функционирования социального субъекта, обеспечивают воспроизводство уже имеющихся форм сознания и поведения индивидов. Таким образом, в представленной типологии стереотипов можно найти критерии анализа их сущности, причины и следствия. Это позволяет научно объяснить поведение людей, особенности их взаимодействия.

\section{References}

[1] Амерханова 3.Ш., Нодирмагомедов А.Н. Ценности традиционной культуры в формировании этнической идентичности девочек-подростков // Этносоциум. 2015. №3. С.118-122.

[2] Данилов С.И. Теоретическое обоснование подхода к формированию национальной идентичности как одной из важнейших основ духовного здоровья личности // Инициативы XXI века. 2012. № 3. С. 130-134.

[3] Хабермас Ю. Историческое сознание и посттрадиционная идентичность. Западная ориентация ФРГ // Хабермас Ю. Политические работы. М., 2005.

[4] Эриксон Э. Идентичность: юность и кризис / Пер. с англ. М., 1996. 


\title{
THE ROLE OF EDUCATIONAL RESOURCES IN 21ST CENTURY EDUCATION
}

\author{
Fayzulina Umida ${ }^{1}$ \\ Khayrullaeva Sarvinoz ${ }^{2}$ \\ Ravshanova Gulkhayo ${ }^{3}$
}

\begin{abstract}
This article is devoted to the use of open educational resources in a university for the organization of the educational process in which models are developed to improve the quality of education of open educational resources used. This article presents the creation of open educational resources, their problems and solutions.
\end{abstract}

Key words: education, resources, training.

doi: http://doi.org/10.15350/F_7/16

Олий таълим жараёнини ташкил этишда ва юқори сифатли рақобатбардош кадрларни тайёрлашда очиқ таълим ресурсларининг ўрни каттадир. Олий таълимнинг сифатини таъминлаш бўйича энг илғор хорижий олий таълим муассасалари томонидан оммавий онлайн очиқ курсларига киритган ўқув курсларидан фойдаланган холда олий таълим тизимидаги субъектларининг коммуникатив компетентлигини ошириш механизмлари ўрганиш ва миллий очиқ онлайн таълим ресурсларини яратиш долзарб муаммолардан хисобланади. Янги таълим моделининг асосий мақсади - замонавий ахборот жамиятини ривожлантириш билан билим талабгорларига максимал юқори даражадаги рақобатбардош таълимни таъминловчи мухитни хосил қилиш: хамкорлик, коммуникация, ижтимоий жавобгарлик, муаммоларни оператив ва сифатли ечиш. Масаланинг бундай қўйилиши фаол ва долзарб контентларни ишлатиш заруратини шарт қилиб қўяди. Очиқ таълим ресурсларини ривожлантириш ва фойдаланишни олға сурмай бундай глобал масалани ечиш имконияти йўқ.

Турли мамлакатларда кўп сонли фойдаланувчилар очиқ таълим ресурсларидан фойдаланиб келмоқда. MIT OCW маълумотларига кўра, уларнинг сайтига хар ой ўртача миллионлаб одамлар ташриф буюради, улардан: 43\% мустақил таълим олувчи фойдаланувчилар; 42\% - талабалар; 9\% - ўқитувчилар -; 6\% - бошқа фойдаланувчилар. Хар йили 2 500,000 дан ортиқ халқаро талабалар Германия онлайн курсларидан фойдаланишади. Кўп курслар машхур Германия Университетлари томонидан тақдим этилган бўлиб, курс охирида махсус Сертификатлар билан тақдирланади. Асосий курслар пуллик бўлсада уларнинг маълум қисми талабаларга бепул равишда, очиқ холатда қўйилганлиги олқишга сазовор. Булар, Германиянинг 409 та университет ва коллежлар томонидан тақдим этилган 14.500 ортиқ халқаро даражадаги дастурлардан иборат.

Германия тармоқларида жудаям машхур бўлган inversity.org сайти шулар жумласидандир. inversity.org олий таълим ва касб-хунарни ривожлантириш учун қаратилган Европанинг рақамли таълим платформаси хисобланади. Веб-сайтнинг

\footnotetext{
${ }^{1}$ Fayzulina Umida, student, Bukhara branch of the Tashkent Institute of Irrigation and Agricultural Mechanization Engineers, Uzbekistan.

${ }^{2}$ Khayrullaeva Sarvinoz, student, Bukhara branch of the Tashkent Institute of Irrigation and Agricultural Mechanization Engineers, Uzbekistan.

${ }^{3}$ Ravshanova Gulkhayo, Student, Bukhara State University, Uzbekistan.
} 
мақсади таълимнинг барча учун очиқлиги, уни арзон ва янада осонлаштириш бўлиб, талабанинг қаерда бўлишидан қатъий назар унинг бутун Европа институтлари томонидан тақдим этилган курслардан сабоқ олиш имконияти билан таъминлашдир. Сайтда интерактив ва қизиқарли, юқори сифатли таълим тажрибасини ўрганиш жуда хам осонлаштириб берилган.

Веб-сайтда курснинг қидирув қисми жуда хам қулай бўлиб, талаба ўзига мос бўлган курсни хохлаган форматда ва хохлаган тилда юклаб олиши мумкин.

Khan академияси - Нотижорат таълим ташкилоти бўлиб, Гарвард Университети битирувчиси Салмон Хон томонидан 2006 йилда асос солинган. Академиянинг мақсади - "хамма жойда хар бир киши учун сифатли таълимни таъминлаш"дир. Академия Веб-сайтида математика, тарих, соғлиқни сақлаш ва тиббиёт, молия, физика, кимё, биология, астрономия, иқтисодиёт, космология, органик кимё, санъат тарихи, микроиқтисодиёт асослари, информатика фанларидан 4200 дан ортиқ бепул микро маърузалар йиғиш имконини беради. Хан Академиясининг таълим бериш усули босқичма-босқич бўлиб, хар бир босқичда сиз маърузага тегишли бўлган видеолавхани томоша қиласиз. Лавхадан сўнг мавзуга тегишли бўлган саволларни видеолавха остида қолдиришингиз мумкин бўлиб, уларга мутахассис жавобини олса бўлади.

edX очиқ онлайн курслардан ташкил топган бўлиб, айрим курслар бепул ўтилади. Веб-сайтда, талаба ўзи хохлаган фанни кенг доирадаги онлайн курслари сифатида энг машхур университетлар томонидан берилган марузалар орқали ўргатилади. Дунёнинг кўплаб Университетлари edX билан хамкорлик қилиб кўпчилик курсларга мезбонлик қилади. Бундан ташқари edX нотижорат ташкилоти бўлиб, шунга ўхшаш Coursera ва Khanakademy ва бошқа онлайн курслардан фарқли ўлароқ, очиқ-кодли дастурда ишлайди. Жумладан хохлаган талаба ва педагоглар маърузаларни ўзгартириш ва янгисини яратишга хақлидир.

Ушбу Веб-сайтларни Массачусеттс Технология Институти ва Гарвард Университети 2012 йил май ойида яратган. 24 март 2016 йилнинг маълумотларига кўра, edX да 7 миллиондан зиёд талаба 700 дан ортиқ онлайн курсларидан сабоқ олади.

$\mathrm{EdX}$ курслари хафталик ўқув кетма-кетликлардан иборатдир. Хар бир дарс видео лавхалардан таркиб топган бўлиб, видео билан биргаликда машқлар ва интерактив масалалардан иборатлиги, талабанинг мавзуни дархол ўзлаштиришига замин бўла олади. Курслар кўпинча тажрибавий видео-лавхалар билан бойитилган бўлиб, Университетнинг мухокама гурухларига ўхшаб кетади. Ундан ташқари онлайн дарсликка ўхшаш сахифаларга эга бўлиб, талабалар бирбирига онлайн сухбат қилиб, марузани мухокама қилишлари мумкин [6].

$e d X$ да Khanakademy дан фарқли равишда ўрганиладиган фанлар доираси жуда хам кенг бўлиб, уларнинг кўпчилиги инглиз тилидадир.

Хар бир курсни бошлашдан олдин, унинг мутахассис-марузачисининг исми шарифи берилган бўлиб, марузанинг қисқача мазмуни, ва бошқа талабаларнинг бундан олдин қуйган изохларини кўрса бўлади, бу талабанинг вақтини тежашга анча ёрдам бера олади [8].

Coursera - тижоратга асосланган дунёдаги энг кўп очиқ онлайн курслар таклиф этувчи, таълим технологияси хисобланади. Coursera да физика, мухандислик, гуманитар, тиббиёт, биология, ижтимоий фанлар, математика, бизнес, информатика, рақамли маркетинг каби фанлардан сабоқ берувчи, энг машхур олий ўқув юртларининг курсларидан мавжуд онлайн база хисобланади.

edX га ўхшаб, Courseraни хам IOS ва Андроид операцион тизимларида ишлайдиган смартфонларга юклаб олиш имконияти мавжудлиги унинг аудиториясини кенгайтиришига ёрдам беради. 
Бугунги кунда айрим курслар бепул тақдим этилсада, асосий маърузалар ва курслар махсус тўловлар асосида юритилади. Курснинг охирида маълум тўлов эвазига талабалар ўз мутахассисликларига мос бўлган компаниялардан сўровларга жавоблар олишлари мумкин.

Бундан ташқари хар бир курс охирида талабалар веб-камера орқали жонли равишда, оғзаки ва ёзма имтихондан ўтишлари мумкин

Хар бир курс одатда 4-10 хафта давом этиб, унинг жараёнида талаба хар хил синов, хафталик машқлар ва якуний лойихалардан ўтиши керак. Бундан ташқари, талабалар шеб форумлар ўтказиб жонли сухбат қилишлари, маърузани мухокама қилишларига имкон яратилгандир. Аммо имтихон синовлари жараёнида шеб форумлар тасдиқланганлиги, унинг якуний жавобларини адолатли равишда берилганлигига асос бўла олади.

Courseraнинг энг асосий камчилиги унинг кўпчилик курслари пуллик равишда ўтилишида бўлиб, унинг талабаларини моддий жихатдан қийинчиликка олиб келиши мумкин [7].

Юқоридаги ОТР фаолиятини ўрганиб Олий таълим муассасаларида иқтидорли талабаларни тайёрлаш моделини яратиш мумкин (1-расм).

Ушбу моделда олий таълим муассасаси талабалари орасидан иқтидорлиларини саралаш ва уларни номдор стипендияларга, давлат мукофотларига, ёшлар иттифоқига аъзо бўлишига тайёрлаш қаралади. Албатта иқтидорли талабалар кафедраларда, фан ўқитувчилар, мураббийлар томонидан маълум бир тест синовлари, илмий лойихаларда иштироки, ташкилий, илмийуслубий ишларда фаоллиги билан аниқланади.

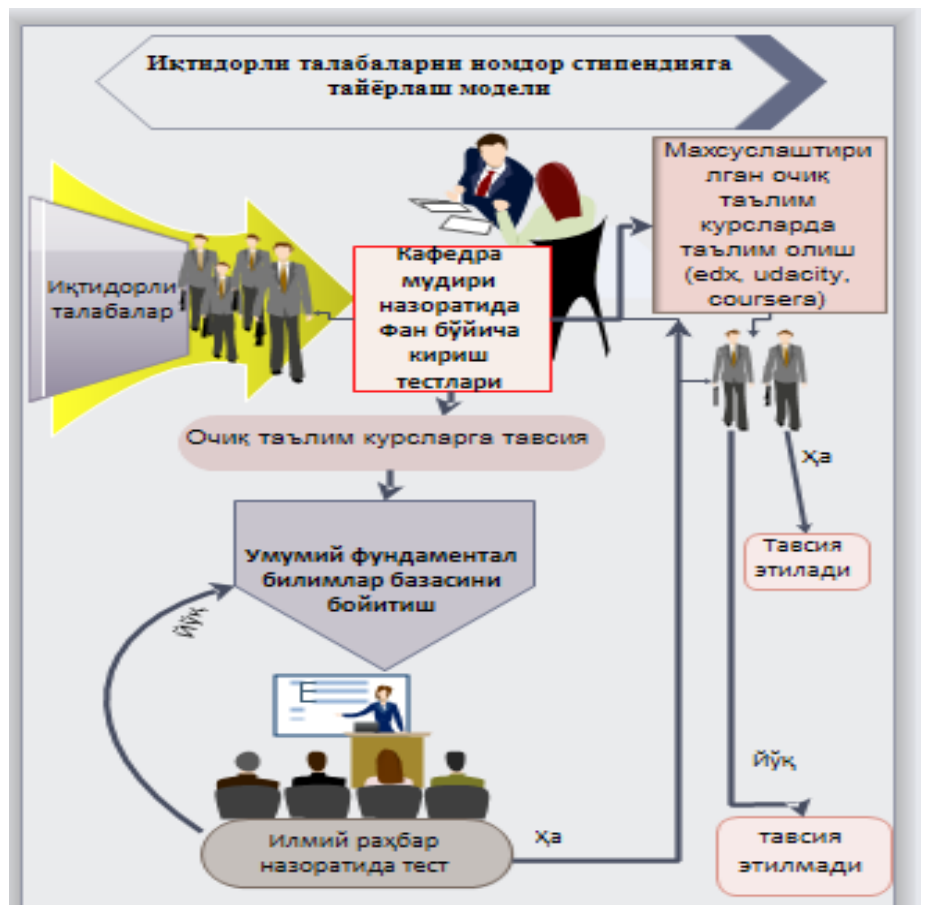

1-расм: Иқтидорли талабаларни тайёрлаш модели 
Мазкур моделда талабалар иқтидорини, қобилиятини, билим ва кўникмаларини очиқ таълим ресурсларидан фойдаланиб аниқлаш, қолаверса талабага ОТР дан фойдаланиш жараёнида билимларини янада мустахкамлаш жараёни келтирилган.

References

[1] Ўзбекистон Республикаси Президентининг "Компьютерлаштиришни янада ривожлантириш ва ахборот-коммуникация технологияларини жорий этиш тўғрисида"ги ПФ-3080 Фармони.

[2] “Миллий ахборот-коммуникация тизимини янада ривожлантириш чора-тадбирлари тўғрисида"ги 2013 йил 27 июндаги Пқ-1989-сон Қарори.

[3] "Creative Commons" ривожланиш истиқболлари Creative Commons нинг Варшавада бўлиб ўтган 2011-йил 16-18-сентябрдаги халқаро саммити.

[4] Nihalani R. Video Is Great, But Unlocking MOOC Data Is The Game Changer. URL: http://www.skilledup.com/blog/mooc-data/

[5] Образовательные программы Coursera. URL:https://www.coursera.org/ about/ programs.

[6] Московский Центр Дистанционного Образования: EDX -самая интеллектуальная MOOC платформа в американском дистанционном образовании. URL: http://bakalavrmagistr.ru/news/177 (дата обращения 16.08.2015).

[7] Педагогические подходы Coursera. URL: https:// www. coursera.org

[8] https://losst.ru/richard-stollman-otets-otkrytogo-programmnogo-obespecheniya 


\title{
THE URGENCY OF THE FORMATION OF A SENSE OF HOMELAND IN THE EDUCATION OF PRESCHOOL CHILDREN
}

\author{
Abdurakhmonova Kamola ${ }^{1}$
}

\begin{abstract}
In today's globalization, one of the main tasks of any state is to bring up children who love their motherland. It is important to start educating children about their homeland from their earliest childhood years, from pre-school age. It is during this period that the mind of the child begins to understand everything. From this moment on, he will be given an understanding of his homeland and his motherland, which will not leave him forever.
\end{abstract}

Key words: history, patriotism, technology, prosperity, youth, consciousness, knowledge, understanding, value.

doi: http://doi.org/10.15350/F_7/17

As the First President Islam Karimov put it", the work to instill a national idea into preschool children should be done with the same care and tenderness as the master gardener grafting on a young tree."

To do this, we must first raise our children in good manners and morals. First of all, the child is given moral support in the family. In addition to family training, kindergarteners also need to teach their child human qualities. In accordance with the Decree of the President of the Republic of Uzbekistan "On Measures for Perfection of Management of the System of Preschool Education" dated September 30, 2017, PF - 5198 The tasks of comprehensive intellectual, moral, aesthetic and physical development were laid on the newly formed Ministry of Preschool Education. Knowledge is a great asset that cannot be bought for any wealth, but only after learning and striving we can gain knowledge.

In the age of information and technology, education and science have become increasingly important. Demand for skilled and qualified professionals is growing. This is because economic, scientific and technological innovations between countries make people with high scientific potential. At the same time, any innovations and inventions should be used for the benefit of the people and the country's development. Otherwise, it could lead to a crisis. In this regard, values play an important role.

National and universal values have a great impact not only on the formation of the individual, but also on the quality of modern education in the society and the socio-economic development of the country. During the years of independence a special attention was paid to the knowledge and appreciation of national and universal values in our country, as well as to the younger generation. Therefore, progress has been made in economic and social spheres, in the spiritual and moral renewal of society. As a result, a new social environment and the value of science based on moral and ethical values were formed in the society. Creation of conditions for educational and moral upbringing of children at the preschool level, provision of the opportunity to choose different programs for different types of preschool institutions and family education, on all issues of pre-school education The use of qualified counseling services implies preparing children for regular school education. For example, when a child is only one year old, he or she immediately separates

${ }^{1}$ Abdurakhmonova Kamola, Student of the New State Pedagogical Institute, Uzbekistan. 
their parents from the crowd. She tries to reach her parents with her little arms. He especially loves his mother more than anyone else and hugs her mother's arms and hugs her tightly around her neck.

Thus, even in these small souls, it is possible to instill love and love for the country, a feeling of respect for adults, a love and respect for nature, all living things and life. It requires us, adults, to be very careful, intelligent and thorough. The lessons emphasize that homeland is sacred, that our ancestors lived in this soil, and that everyone should work for the prosperity of the country and children develop love for the country. It should be noted that in this process, both adults and children have a special role in preserving the independence and peace of our country. Celebrating the birth of our great ancestors is also a good result in instilling the idea of national independence in the minds of children. Because the boy is Amir Temur, Alisher Navoi, Bobur. In the process of preparing to celebrate the birth of great people such as Ibn Sina, they learn how they lived and what they are like, imitating them and proud of them. The game is a favorite activity of children. It is through these games that we can find an easier way to reach hearts. Storytelling together, traveling to nature. fairy tales, poems and short stories, listening to music give children a world-wide impression that gives them a sense of enjoying nature and the environment."Uzbekistan - my motherland" - "Prosperous land", "I am a child of Uzbekistan" It is good for me to organize various conversations, debates and discussions on topics such as my honor. The condition of the rapidly changing environment reflect the importance of human capital and its use. We know from many years of experience that values are a very important factor in the formation of a person, maintaining national and universal qualities, as well as the training of leading specialists in the education system.

\section{References}

[1] Karimov.I.A. "High spirituality - invincible power" T. "Ma`naviyat" .2008y

[2] G.Alimova, J.Kamolov, Sh. Abdullayeva.Partnership of family- the neighborhood-educational institution.T.,2014y

[3] https://www.lex.uz/docs/-3362886

[4] http://uza.uz/uz/documents/o-zbekiston-respublikasi-maktabgacha-ta-lim-vazirligi-faoliy-02$10-2017$ 


\title{
EDUCATION REFORMS IN THE REPUBLIC OF UZBEKISTAN: MODERN SCHOOLS AND MODERN EDUCATION
}

\author{
Abrorjon Sadriddinov ${ }^{1}$
}

\section{Abstract}

This article highlights the legal basis of educational reforms in the Republic of Uzbekistan during the years of independence, as well as the importance of educational reforms implemented directly by President Shavkat Mirziyoyev in modern Uzbekistan, and their goals.

Key words: right to education, UN, UNESCO, Convention on the Rights of the Child, Law on the Rights of the Child, Schools of Creativity, Specialized Schools, Presidential Schools.

doi: http://doi.org/10.15350/F_7/18

On August 31, 1991 (September 1 - marked as «Independence Day»), a new independent Republic of Uzbekistan was established on the world map. From the first years of independence in Uzbekistan, the development of the education system has risen to the level of state policy, ensuring that the younger generation acquires modern knowledge and skills in accordance with world standards, grows up physically and spiritually mature people. Great work is being done to cultivate their abilities and talents, to realize their intellectual potential, to cultivate in their hearts a sense of devotion and devotion to the motherland.

In accordance with Article 41 of the Constitution of the Republic of Uzbekistan, adopted on December 8, 1992, in Uzbekistan all gender, language, age, race, nationality, beliefs, religion, social origin, type of service, equal rights to education are guaranteed to everyone, regardless of social status, place of residence. On March 2, 1992, Uzbekistan became a member of the United Nations, and on October 29,1993, a member of the United Nations Educational, Scientific and Cultural Organization (UNESCO). UNESCO's main educational program is the United Schools Program, which has more than 6,000 schools around the world. The National Commission of the Republic of Uzbekistan for UNESCO, established on December 29,1994, is actively working to develop this sector in our country [1].

On December 9, 1992, Uzbekistan acceded to the Convention on the Rights of the Child. On January 7, 2008, the Law of the Republic of Uzbekistan «On Guarantees of the Rights of the Child» was adopted [2]. Article 23 of this law stipulates that every child has the right to education and free compulsory general secondary education is guaranteed by the state.

On August 29, 1997, a new version of the Law on Education and the National Training Program were adopted.

The most important foundation of cultural and spiritual development is the education system. Because it is impossible to raise the society without training the personnel who meet the requirements of the time, advanced science and technology. Therefore, from the beginning of the XX century, the education system of Uzbekistan began to develop on the basis of modern standards. The educational reforms of the President of the Republic of Uzbekistan, Shavkat Miromonovich Mirziyoyev were especially important.

\footnotetext{
${ }^{1}$ Abrorjon Sadriddinov, The history teacher at the Presidential School in Namangan, Uzbekistan.
} 
Development of direct education and science in the IV direction of the «Action Strategy» on five priority areas of development of the Republic of Uzbekistan for 2017 2021, No. PF-4947, adopted on February 7, 2017 structured. The most important task of our time is to educate the younger generation, to bring them up as physically and spiritually mature people [3].

On September 19, 2017, at the 72nd session of the United Nations, President Sh.Mirziyoyev proposed the adoption of a special resolution of the UN General Assembly entitled «Enlightenment and Religious Tolerance», the main purpose of which is the right to education and to eradicate illiteracy and ignorance.

President Sh. M. Mirziyoyev's reports critically analyzed the state of affairs in the field of education and science, the implementation of state youth policy, the introduction of new modern methods of education, including information and communication technologies. They emphasize that the implementation of urgent tasks in this area is of strategic importance for the future of our youth, society and our country [4].

In order to fully develop the talents and abilities of young people, to support their aspirations to acquire science, to realize their dreams, to create a quality education system in a short period of time in the Republic creative schools, specialized schools and Presidential schools have been set up.

Today in Uzbekistan modern creativity and specialized schools under the names of Abdulla Aripov, Erkin Vahidov, Ogahi, Ishakhon Ibrat, Halima Khudoiberdiyeva, Abdulla Qodiri, Muhammad Yusuf, Hamid Olimjon and Zulfiya, Ibrahim Yusupov, Muhammad al-Khwarizmi, Mirzo Ulugbek, Abu Ali Ibn Sino are functioning [5].

On February 20, 2019, in accordance with the Presidential Decree No. PP-4199 «On measures to establish presidential schools», Presidential schools based on modern projects were built in Tashkent, Khiva, Nukus and Namangan. These schools have all the necessary conditions for students to study natural and exact sciences, foreign languages, engineering and information technology. The program «STEAM - education» (Science natural sciences, Technology - technologies, Engineering - technical creativity, Art - art, Mathematics - mathematics) has been introduced in the presidential schools, and the educational process is fully in English. Highly qualified foreign specialists were involved in the educational process of the presidential schools. In accordance with the «Regulations on Presidential Schools», graduates of presidential schools are provided with access to leading higher education institutions of foreign countries, along with a document (certificate, diploma) and international program diploma (International Baccalaureate, Advanced Placement or International Advanced Levels) on the information approved by the state in the prescribed manner [6].

The main goal of the educational reform in modern Uzbekistan is to introduce modern methods of teaching and assessing students, as well as an interdisciplinary approach to teaching based on the integration of educational programs, and then to introduce the positive experience of the people of the republic.

In accordance with the Decree of the President of the Republic of Uzbekistan dated April 29, 2019, the Concept of Development of the Public Education System until 2030 was approved [7]. By 2030, Uzbekistan is set to be among the top 30 countries in the world in the ranking of the international student assessment program PISA.

\section{References}

[1] https://lex.uz/docs/889569 yangi tahrirda https://lex.uz/docs/4739759

[2] Ўзбекистон Республикаси қонун хужжатлари тўплами, 2008 й., 1-2-сон, 1-модда, 2009 й. https://lex.uz/docs/1297315

[3] Мирзиёев Ш. М. Эркин ва фаровон, демократик Ўзбекистон давлатини биргаликда барпо этамиз. - Т.: Ўзбекистон, 2016. - Б. 13. 
[4] Мирзиёев Ш. М. Танқидий тахлил, қатъий тартиб-интизом ва шахсий жавобгарлик - хар бир рахбар фаолиятининг кундалик қоидаси бўлиши керак. - Т.: Ўзбекистон, 2017. - Б. 44.

[5] Қонун хужжатлари маълумотлари миллий базаси, 12.03.2020 й., 09/20/141/0286-сон. https://lex.uz/docs/4761058

[6] Қонун хужжатлари маълумотлари миллий базаси, 26.06 .2019 й., 09/19/526/3338-сон. https://lex.uz/docs/4387224

[7] Қонун хужжатлари маълумотлари миллий базаси, 29.04.2019 й., 06/19/5712/3034-сон. https://lex.uz/docs/4312785 


\title{
PROSPECTS FOR AN INTEGRATIVE APPROACH IN THE FIELD OF PHYSICAL EDUCATION TEACHING
}

\author{
Abytova Jasmine 1
}

Sattorova Parvina ${ }^{2}$

\section{Abstract}

The article presents views on the importance of carrying out scientific activity integrating general subjects related to profession in Physycal Education sphere and other adjoining subjects maintaining cooperation between departments.

Key words: integration of disciplines, competency approach, interdisciplinary connection, scientific problem, innovative technology.

doi: http://doi.org/10.15350/F_7/19

Today, such important tasks as strengthening the scientific potential in higher educational institutions, further development of scientific research in the higher education system, strengthening their integration with academic science, improving the efficiency of scientific activities of the teaching staff, and attracting talented young people to scientific activities occupy a special place.

Integration of Sciences is a combination of Sciences, which means that the topics are not repeated, saving time, that is, it allows you to master a large amount of material with less time, and also represents an organizational task.

There are several main factors that influence the basics of integration:

- the objective laws of development of science;

- definition of the content of education taking into account the development of science;

- state educational standards;

- learning functions;

- synthesis of knowledge;

- educational process and content unit;

- mutual definition of curricula and programs;

- material and technical base;

- innovative technology.

Continuity in education is understood in two different ways:

1. Continuity between types of education. At the same time, the content of the next type of education not only continues its previous one, but also partially repeats, dividing it by content, which gives grounds for its continuation in subsequent types of education.

2. Continuity between academic disciplines. This is commonly referred to as"interdisciplinary communication". The organization of the teaching staff's work on the problem of interdisciplinary relations includes two main and interrelated areas: tions;

- planning the educational process taking into account interdisciplinary connec-

\footnotetext{
${ }^{1}$ Abytova Jasmine, teacher of the faculty of physical culture, Bukhara state University, Uzbekistan.

${ }^{2}$ Sattorova Parvina, student of the faculty of physical culture, Bukhara state University, Uzbekistan.
} 
- management of joint educational and methodological works of teachers of related Sciences on the introduction of interdisciplinary connections, final qualification work, master's thesis.

Comprehensive study of the laws of physical education (pedagogical) through a deep analysis of its laws, large-scale innovative technologies with their effectiveness in modern education explain the way to practice through knowledge that allows you to understand the mechanism of purposeful impact on the development of the human body.

To date, there have been such integral complex areas of science, in which, along with the fact that their object is the process of physical education, including directly related phenomena.

According to the theory of physical education, these traditional fields of science are divided into two groups:

1. Fields of science of a humanitarian nature are aimed at knowing the social laws of the development of physical education, its history and organization in society, the formation of its content and integral system, or at analyzing the process of physical education and its impact on a person in certain socio-pedagogical and psychological-pedagogical aspects.

2. Mathematics and natural science (mathematics, computer science and information technology, human anatomy and physiology, ecology and nature protection) are certain laws related to the functional development of the body in the conditions of physical education, and determine its rational conditions in the natural-scientific, medical and hygienic areas.

The fact is that the fields of mathematics and natural science are only able to reveal the essence of physical education as a separate process or regularities in their own directions.

No matter how deep and significant scientific knowledge these areas of science possess, they are not able to create in their field a sufficiently complete, comprehensive understanding of holistic physical education. Because if you do not find your General reflection in the facts, scientific reasoning, features and relationships of the system of physical education, studied in a particular field of science, the integrity (pedagogy) will break away from the reality of the phenomenon. It is the theory and methodology of physical culture that can ensure the integrity of science, or rather, introduce innovative ideas in the effective solution of educational, educational and health problems through other areas of science.

The subject "Theory and methodology of physical culture", taught as part of the "Humanities", is characterized by a greater generalizing system of theoretical, methodological and scientific knowledge about physical education, as well as the possibility of integrating the Sciences into the higher education system. This is a synthetic science by combining data from other fields of science that are important in teaching the laws of physical education, as integrity, completeness. In one example, we can learn the mechanisms of influence of physical activity parameters on the body's functions (blood circulation, respiration, nervous system) not only from a pedagogical point of view, but also by analyzing (synthesizing) the system of laws of physics, psychology, and biomechanics of science. It should also be recognized that often the information determined by individual methodologies of other fields of science can not be fully associated with their integration within the subject "Theory and methodology of physical culture", since these data only contribute to understanding the essence of the General laws of the holistic pedagogical process of physical education aimed at educating a harmonious person. 
References

[1] Kozlenko N. P. Velichkovsky E. C., Cvek S. F. the Theory and methods of physical education. - K., 1984. - $220 \mathrm{p}$.

[2] Kachalkin V. M. Methods of physical education. - Moscow, 1980. - 304 p.

[3] Matveev L. P. Theory and methodology of physical culture. - Moscow, 2011. - 443p.

[4] Theory and methodology of physical education / ed. by B. A. Ashmarin. - Moscow, 2018. - 287 p. 


\title{
SOME ISSUES OF SPORTS TRAINING PLANNING
}

\author{
Arslonov Qahramon ${ }^{1}$ \\ O'roqova Saodat ${ }^{2}$
}

\section{Abstract}

The article considers the problems of planning students' preparation for sports.

Key words: preparation for sport, physical development, the outlook of a sportsman, developing a skill, technic, tactic preparation, physical qualities, planning, competition.

doi: http://doi.org/10.15350/F_7/20

Before you start planning a sports training session, you need to define its goals and objectives. The main purpose of sports training exercises is to train highly qualified athletes. In order to solve this main issue, you need to pay attention to the following questions in training.

Question of education. Training of an athlete goes through the following stages:

1) formation of his worldview, interest in himself, to others;

2) provides education of the creative and cognitive ability of an intellectual;

3) education of the aesthetic environment, acceptance of beauty in work and sports activities; solve it.

4) willpower-is aimed at educating the athlete's ability to set a goal and strive to

The plan of sports training exercises is made for different training processes that have their own specific tasks and goals. Long-term planning usually lasts 4 years. This includes the period from one Olympics to another or from one Olympics to another. This planning involves preparing talented athletes for the Olympics in educational institutions. This planning allows you to prepare for competitions in an organized and uniform way. The main goal of long-term planning is to educate an athlete in a special quality and raise him to reach sporting heights.

According to many physical education experts, annual planning of sports training is of paramount importance. Preparation for sports activities depending on the tasks and goals set for the year, as well as the level of sports training, the annual plan will be as follows:

a) one-time planning of sports training exercises. This planning includes one preparation, one competition, and one transition period at the end of the cycle. This planning is applied to athletes who plan to participate in 1-2 events a year, but they are held in a short period of time, until the month when the competition will be held.

Single-period planning has its advantages, in particular: the training period is long, each physical quality allows for a separate detailed development and development of individual athletic qualities in the athlete. At the same time, a lot of time is devoted to training each quality, and their improvement is planned with an emphasis on all means and methods. As mentioned above, single-period planning is mostly structured for novice athletes and allows some talented young athletes to "not miss out" on some of their abilities that can only be demonstrated over a long period of time;

\footnotetext{
${ }^{1}$ Arslonov Qahramon, associate Professor of the faculty of physical culture, Bukhara state University, Uzbekistan.

${ }^{2} O^{\prime}$ roqova Saodat, master's student of the faculty of physical culture, Bukhara state University, Uzbekistan.
} 
b) two-period planning.

The difference between these two sports training plans is not so great: with twoperiod planning, there is a transition period at the end of each period. This scheduling is used when there are two or more deadlines between competitions, while the "single-period plan" is one at the end of the year.

The advantage of such planning is that if the planned results are not achieved in the first period, this can be achieved by changing the tools and methods in the second period. At the same time, sports training allows you to prepare for the second period much more effectively, as a result of physical rest of the athlete between periods of the year;

c) multi-period planning.

This planning is used in cases where 3 or more competitions are held in one year, and the period between starts must be more than 1 month. Using multi-period planning allows you to prepare more effectively for each competition process, as well as reduce the duration of the competition period.

A short period is one of the main elements of the preparatory process. The duration of a short period can be from 4 to 1 day.

The main core of short-term planning is the laws of fatigue and fullness of strength. The short period is divided into 5:

a) the initial period prepares the body for heavy exercise. Their combined total weight is usually small; cises;

b) shock-the period of stimulation of adaptation processes to a large set of exer-

c) convergence period-brings the athlete directly to the preparation for the competition, characterized by maximum and submaximal load;

d) competition period-training sessions are formed in accordance with the competition program;

e) the recovery period is a short period of normal recovery of the body, that is, bringing it into a favorable state of equilibrium for the performance of work.

Training to prepare for sports. The number of training sessions per week is determined depending on the athlete's level of training. Any training is divided into three parts:

a) training part-takes $20-22 \%$ of the total exercise performed.

The main thing is to warm up the body, prepare for the upcoming work, training. Depending on the goals set for this exercise, a General developmental exercise is formed;

b) the main part of the lesson takes about $60-65 \%$ of the time in duration.

Usually, training begins with special exercises that are aimed at partially solving issues of physical activity. The task of the main part of the preparatory training can be aimed at training, development or improvement, in which the task is solved using various means and methods;

c) the final part of the lesson takes $10-12 \%$ of the time, this is the main issue, work at home is given so that the student can restore his body, consider the results of training and, if necessary, do it yourself.

\section{References}

[1] Grigoriev 0. A., Gorelov A. A., Sysoev V. I.: Theoretical bases of sports training and training. - Moscow: Evroshkola, 2010.307p.

[2] Rodichenko V. S.: Sports competitions: information, management. - Moscow: physical Culture and sport, 1978. 230p. 


\title{
PROBLEMS OF OPTIMIZATION OF ACTIVITY OF STUDENTS IN ELEMENTARY CLASSES BY MEANS OF PHYSICAL MEANS
}

\author{
Juraev Zhura ${ }^{1}$ \\ Muhiddinov Mirshod ${ }^{2}$
}

\section{Abstract}

The article analyzes the optimization of physical activity of elementary school students by physical means.

Key words: activity, Analysis, Athletics, Gymnastics, level.

doi: http://doi.org/10.15350/F_7/21

Развитие образования и воспитания нового поколения учитывает необходимость всестороннего и гармоничного развития каждого человека, и наше государство придает большое значение интеграции физической культуры и спорта в эти процессы.

Одной из основных задач физического воспитания учащихся школьного возраста является улучшение их здоровья, улучшение физической формы и снижение заболеваемости. Потребность в мобильности является необходимой биологической потребностью и является важным фактором роста и развития студенческого сообщества. мобильность определяет функциональные способности ученика и способность выполнять работу. Повышенная активность способствует активации всех основных физиологических функций организма, повышает активность сердечно-сосудистой и дыхательной систем и повышает обмен веществ.

Способствует активной мышечной деятельности и развитию мышц и суставов костей. Улучшает координацию движений. Улучшает функции центральной нервной системы.

Круглогодичные упражнения, бег и прыжки имеют особое значение для повышения дыхательной активности учащихся. Такие тренинги помогают укрепить здоровье и благополучие учащегося в борьбе с простудой.

В то же время система физического воспитания неоправданного ранее существовавшего населения, в том числе основанная на этой системе образования, которая не учитывает региональные этические условия и традиции, не решает проблем, с которыми мы сталкиваемся.

Поэтому дальнейшее совершенствование физического воспитания и спорта должно основываться на рассмотрении его сущности, цели, содержания и организации. Физическое воспитание учеников школьного возраста должно использоваться в каждой школьной обстановке на основе правильно выбранных средств, форм и методов физического воспитания с учетом возрастных и половых особенностей учеников.

1Juraev Zhura, lecturer at the Department of "Theories and Methods of Physical Culture" of Bukhara State University, Bukhara, Republic of Uzbekistan.

${ }^{2}$ Muhiddinov Mirshod, student of the Faculty of "Physical Culture" of Bukhara State University, Bukhara, Republic of Uzbekistan. 
Физическое воспитание не легкая задача. В наше время дети и подростки в современных условиях практически не нуждаются в движении. Ученики школьного возраста проводят большую часть своего времени перед телевизором и компьютером, а также рисуют, выполняют задания, слушают разные истории и так далее. Студентов не интересует, интересуются ли они специалистом по физическому воспитанию, который делает все, чтобы активировать свою мобильность, вовлечен ли каждый студент в учебный процесс или кто равнодушен к обучению.

В течение долгого времени ученикам больше всего нравятся подвижные игры и игровые упражнения. Это позволит вам получать удовольствие и необычные игры. Практика показывает, что правильно подобранные и продуманные игровые упражнения, направленные на развитие физических качеств, оказывают благотворное влияние на физическое развитие учащихся. Они могут включать в себя субъективные упражнения (прогулка в саду, бегун и сакраменто, всезнающий) и многое другое.

Знания и убеждения человека, ценность и мотивация - структура систем потребностей, которые организуют и направляют их в восприятие и практическую деятельность. Активное отношение к физическому воспитанию демонстрирует необходимость ежедневных упражнений с упором на здоровый туризм и физическое совершенство.

Проблема физического воспитания школьников является одной из важнейших задач на данном этапе. Это важный этап в развитии навыков физического здоровья и культуры, которые обеспечивают благополучие человека, стабильность и выживание в будущем. Именно поэтому результатом физического воспитания школьного возраста должно стать построение здорового студенческого тела и основы физической культуры будущего человека, которая включает в себя:

- Эмоциональное и позитивное отношение к занятиям, которые стимулируют учащихся к упражнениям и играм, а также влияние сил здоровья, личной гигиены и на повестку дня.у

- базовые навыки Школы естественного движения с общим развитием, основами музыкальных и ритмических знаний, правильного обращения с телом, умением вести себя по кругу, участием в коллективных действиях (играх, танцах, праздниках), знанием поведенческой культуры, самостоятельности, организации, дисциплины.

- Навыки самообслуживания и навыки использования снаряжения, инвентаря для обучения.

Для учащихся начальной школы основное внимание уделяется верховой езде. Но в этом возрасте для ученика очень важно бегать, кричать и прыгать.

Развитие действий имеет особое значение. Для этого целесообразно использовать подвижные игры для активного отдыха - индивидуальные и командные игры, упражнения.

Таким образом, представляется, что роль и роль активизма в выполнении следующих основных задач физического воспитания у учащихся начальных классов: Укрепление здоровья, правильного физического развития и закаливания студентов.

1.Дать студентам специальные знания по физической культуре и спорту, дать им гигиенические знания и навыки. Формирование и совершенствование умений и навыков учеников, обучение новым видам движения и деятельности.

2. Развитие основных поведенческих характеристик (сила, ловкость, ловкость, выносливость и т. Д.) С возрастом. 
3.Совершенствование навыков культурного поведения, отношения к работе, смелости, стойкости, дисциплины, командной работы, дружбы.

Физическое совершенствование человека предполагает уровень его физического развития, психофизиологические и физические возможности, которые составляют основу его активной творческой, социально значимой деятельности.

References

[1] 1.Кудратов Р.К., Орипов Ю.Ю. Сравнительный анализ техники метательных движений в младших класса //Теория и методика физической культуры. - Алматы, 2001.- №2. - С. 77. 


\section{SCIENCE AND ITS ROLE IN MODERN SOCIETY}

\section{Kamolova Sabrina ${ }^{1}$}

\section{Abstract}

What is the role of science plays in modern education. By means of scientific knowledge a person understands the world. The great role of science in modern society is that it cannot be managed without certain knowledge. Scientific knowledge has led to changes in the social structure of society: more and more people are involved in mental work, and the number of unskilled workers has declined. Science is directly influences people through education.

Key words: mental workers, result of scientific, technological progress, scientific knowledge, inevitability of scientific, environmental risk, the industrial.

doi: http://doi.org/10.15350/F_7/22

The twentieth century was a triumphant scientific revolution. NTP has accelerated to all developed countries. Gradually, the high technology intensity of the products increased. Technology has changed production methods. By the middle of the 20th century, factory mode of production dominated. In the second half of 20th century automation become common towards the end of the 20th century high technologies have evolved, and the transition to the information economy has continued. All these changes happened because of the development of science and technology. These have had several consequences. First, increasing demand for staff. They began to demand new knowledge as well as new technological processes. Secondly, the percentage of mental workers, scientists whose activities are required deep scientific knowledge. Thirdly, as a result of scientific and technological progress and the solution of many pressing problems of society, the growth of welfare has created a confidence in the ability of science to solve human problems and improve the quality of life. This new belief reflected in many areas of culture and public opinion. Advances in space exploration, nuclear power generation, and early advances in robotics have given rise to confidence in the inevitability of scientific, technical and social development, and have risen to the hope of a faster solution to such problems as hunger, disease and so on.

The role of science as a social force is crucial in addressing to the global challenges of our time. An example of these are environmental problems. They are well-known that rapid scientific and technical progress is one of the main causes for the society and man for such dangerous phenomena as the planet's natural resources, air, water and soil pollution. Therefore, science is one of the factors in the rapid and harmless transformation that is taking place on the human environment today. Scholars themselves do not hide this. Scientific data play a leading role in determining the extent and parameters of environmental risk.

The growing role of science in the life of society has given it its special place in modern culture and new features of its interactions with different layers of social consciousness. In this regard, the problem of scientific knowledge and its relationship with other forms of cognitive activity (art, ordinary consciousness, etc.) are very relevant.

\footnotetext{
${ }^{1}$ Kamolova Sabrina, student of Bukhara state University, faculty of pedagogy. Republic of Uzbekistan.
} 
The main criteria for differentiating the functions of science should be taken into account, the basic activities of scholars, the scope of their tasks, and the areas of application and consumption of scientific knowledge.

There are some key features:

1)The cognitive function is given by the very essence of science, the main purpose of which is the knowledge of nature, society and man, the rational and theoretical understanding of the world, its laws, the interpretation of various events and processes, the production of predictive activity. new scientific knowledge;

2) The function of worldview is, of course, closely related to the first, the main purpose of which is to develop the scientific outlook and scientific outlook of the world, to study the rationalistic aspects of human relations with the world, to justify the scientific worldview; but philosophy certainly plays a leading role in this;

3)The industrial, technical and technological function is called for the introduction of innovations, innovations, new technologies, forms of organization and so on. Researchers call science a direct productive force of society, a special "workshop" of science production, and link with scientists. They talk and write about their connections, efficient workers and all these clearly describe these function of science;

4) The cultural and educational functions. Science is an important factor in the cultural phenomenon, the cultural development of people and education. Its achievements, ideas and recommendations influence on the entire learning process, programs, plans, textbooks, technologies, forms and teaching methods. Certainly, the leading role here belongs to pedagogy. This function of science is carried out through cultural events, policies, educational systems and the media, educational activities of scientists and so on. We must not forget that science is a cultural phenomenon and it has a direction and plays a very important role in the field of spiritual production.

Today we can say that in modern society science plays an important role in many areas and spheres of human life. And, of course, the level of development of science can serve as one of the key indicators of economic, cultural, cultural, educational and modern development of society.

\section{References}

[1] Utanov.U - Pedagogical skills. 2016

[2] International Journal of Instruction, October $2017 \bullet$ Vol.10, No.4

[3] 3. Wayne, A. J., \& Youngs, P. (2003). Teacher characteristics and student achievement gains: A review. Review of Educational Research, 73(1),

[4] F.D. Khayotovna, Q.B. Samadovich Method of teaching roman numbers on different examples in initial classes. Journal of Global Research in Mathematical Archives (JGRMA) 6 (11), 46-51

[5] Файзиева Д.Х. Установление разговорного тракта в IP-телефонии // Молодой ученый. 2017. — №4. — С. 113-114. 


\section{METHODS FOR DETERMINING THE DEGREE OF PHYSICAL FITNESS}

\section{Yusupova Zulfizar ${ }^{1}$}

Rakhimova Laylo ${ }^{2}$

\section{Abstract}

The article analyzes the methods used to determine the level of physical fitness of students.

Key words: activity, analysis, athletics, gymnastics, level.

doi: http://doi.org/10.15350/F_7/23

Физическое воспитание играет особую роль в комплексной системе развития человека. Именно в этом возрасте он приспособлен к крепкому здоровью, высокой работоспособности, и именно в эти годы начнутся ранние физические нагрузки и физические тренировки. Известно, что недостаток научных знаний не только отрицательно влияет на здоровье учащихся, но и ухудшает их умственные способности, отстает от общего развития и отвлекает учащихся от окружающей среды. Учащиеся должны усердно работать в своей повседневной жизни и на тренировках. Бездействующий студент не становится здоровым. Действие заключается в предотвращении различных заболеваний, особенно заболеваний сосудов, дыхательных путей и нервной системы.

Уровень физической подготовленности учащихся начальной школы определялся по специальным тестам. К ним относятся:

а) бег на расстоянии 30 м (секунд);

б) бег $4 \times 10$ м (c);

в) взвешивание (иногда) на турникете;

г) крутить руки на длинном сиденье (раз);

г) два удара (метр, см) в положении сидя весом 1 кг;

е) нацеливание на маленький шарик 10 раз с 10 метров (м, раз).

Вышеуказанные конкретные тесты направлены на развитие способности учащихся действовать.

Исследование было организовано в 2 этапа. Первый этап был сосредоточен на теоретическом анализе проблемы, педагогических наблюдениях, разработке методов исследования, основанных на опыте предмета. Источники литературы по физическим видам спорта (легкая атлетика, гимнастика, футбол, спорт и народные игры) были изучены и проанализированы.

Второй этап продолжился при непосредственном участии автора в организации и проведении экспериментальной работы в школе № 316 в Шайхантахирском районе Ташкента. Результаты итогового эксперимента были проанализированы, сравнены, обобщены, данные обработаны с использованием математических и статистических методов.

\footnotetext{
${ }^{1}$ Yusupova Zulfizar, Lecturer, Department of Theory and Methodology of Physical Culture, Bukhara state University, Uzbekistan.

${ }^{2}$ Rakhimova Laylo, student of the faculty physical education, Bukhara state University, Uzbekistan.
} 
Выявлены результаты физического воспитания (младшие и средние классы) младших классов в развитии двигательных навыков. Полученные данные приведены в таблице 3.3 .

Согласно Таблице 3.5, способность учащихся выполнять интенсивные упражнения снизилась с 0,2 до 0,6 секунд каждый год.

Разница в результатах мальчиков при беге с 30 -метрового старта составляет 0,2 секунды между I и II классами, разница между II и III классами составляет 0,3 секунды, или 0,6 секунд между III и IV классами.

Для девочек это 0,$1 ; 0,3 ; 0,5$ секунды Эти цифры показывают, что мальчики и девочки не сильно отличаются по своей производительности в элементарных упражнениях.

Согласно литературным источникам, среднее число мальчиков и девочек в классе I, бегущих на 30 метров, составляет 7,6-8,7 секунды, 6,9-7,1 секунды для класса II и 6,6-6,9 секунды для класса III. по нашим данным 7.1-7.2; 6,9-7,2; 6,6-6,7; 6,0-6,4 секунды. Нет разницы между эффективностью учащихся начальной школы в средних школах № 27 и № 243, которая предназначена для экспериментов.

Разница между результатами I-II юношей в 4х10-метровом показателе скорости составляла 0,2 секунды, разница между II и III классами составляла 0,6 секунды, а разница между III и IV классами составляла 1,3 секунды. Результаты для девочек были 0,$3 ; 0,1 ; 0,8$; секунд.

Результаты теста на поворот турели при определении мышечной силы. Анализ результатов этого теста показывает, что у мальчиков I-IV сила мышц увеличилась в 2,5 раза по сравнению с исходным уровнем; 1 раз для I-II классов, 1,5 раза для II-III классов; Увеличение в 0,4 раза в III-IV классах. При этом сила во II и III классах росла.

Разница в результатах упражнений для запястья и запястья девочек, основанных на гимнастическом сиденье, была в 2,0 раза между I-II классами, в 2,4кратной во II-III и в 0,8 раза в III-IV.

Из данных видно, что в I-IV классах мышечная сила девочек существенно возрастала с каждым годом.

Следует отметить, что результаты, полученные учениками общеобразовательных школ в Ташкенте, являются менее односторонними.

Результаты показаны в двух ручных упражнениях на 1 кг сидячего положения: разница между I-II классами у мальчиков составляет 0,7 см; 0,3 см во II - III степени; В III - IV классах это было 0,5 см. Анализ результатов этого теста показывает, что разница между исходным уровнем и мальчиками IV степени составляет 1,5 см. Результаты, показанные девочками: 0,1 см между I-II классами; 1,2 см во II - III степени; 0,1 см в III - IV классах.

Приведенные выше данные показывают, что учащиеся из протестированных нами школ оцениваются как «хорошие» и «удовлетворительные».

Нет статистической разницы $(\mathrm{P}<0,05)$ между результатами первых 5 тестов между мальчиками и девочками.

\section{References}

[1] Усмонходжаев Т.С., Мелиев Х.А., Орипов Ю.Ю. Практическая реализация задач физического совершенствования у детей равных возрастных групп с учетом их двигательной активности // Актуальные проблемы теории и практики физической культуры: Тез.докл. Междун. научно-практическая конф. (13-14 апрел 2001г). - Алматы, 2001. С. 238-240. 


\title{
STRESS TOLERANCE OF TEACHERS AS THE ABILITY TO PREVENT CONFLICTS
}

\author{
Karimova Vasila ${ }^{1}$ \\ Mirzabdullaeva Dilxumor ${ }^{2}$
}

\section{Abstract}

This article discusses the pedagogical conflicts that arise in the process of teaching and upbringing between teachers and students, as well as the ability of a teacher to stress resistance that contributes to the prevention of conflicts.

Key words: conflict, ability, teacher, stress tolerance.

doi: http://doi.org/10.15350/F_7/24

Stress is an almost inevitable consequence of any conflict. Its unpleasant signs (increased excitability, inability to concentrate, a sense of gratuitous fatigue, etc.) appear instantly and are visible, as they are called, to the naked eye. "Not nervous.», «Relax.",- advise us surrounding. Yes, we would be happy not to be nervous, but it does not work, a Stressful situation captures us and does not let go: unpleasant thoughts "themselves climb" into the head, harsh words fall from the lips themselves... So after all, a serious illness is not far away. Is there anything you can do about it? It is possible, but only under three conditions: 1 ) a clear understanding of the nature of stress and the stages of its development; 2) a clear idea of the limits of possible impact on the course of a stressful situation; 3) readiness for active efforts to achieve stress resistance.

Pedagogical communication is a difficult problem to study. The most acute topic is conflicts between teachers and teenagers, as well as the study of rules of behavior in conflict situations and effective strategies for their resolution.

Conflicts in pedagogical communication that lead to the accumulation of negative experiences of interaction with teachers and peers within an educational institution hinder the full development of the individual, which contradicts the main goal of education and upbringing in the Republic of Uzbekistan.

Foreign philosophers, psychologists, teachers, sociologists: William McDougall, Herbert Spencer, Conrad Laurence, Kurt Levin, Sigmund Freud, Georg Simmel, Lewis Kozer, Kenneth Boulding: L. S. Vygotsky, N. E. Shchurkova, V. M. Afonkova, V. I. Zhuravlev, G. M. Andreeva, A. I. Shipilov, O. S. Grebenyuk, A. Ya. Antsupov, A. A. Lobanov, E. V. Burtova, V. Yu. Pityukov, M. I. Stankin, M. M. Rybakova, A. S. Chernyshev, S. V. Banykina, etc.

Conflicts in the pedagogical process are inevitable. The profession of a teacher is recognized as one of the most difficult, in its psychophysiological intensity, it is at the level of test pilots and climbers. Therefore, one of the problems in pedagogy is the issue of constructive conflict resolution.

A teacher who does not avoid conflicts, but seeks to resolve them, gains invaluable personal experience in managing them. He comes to understand the motives of students ' behavior, gradually developing skills of forecasting and managing them. Understanding these problems gives the teacher a real opportunity to direct the energy of interpersonal conflicts to improve the process of education and upbringing of students.

\footnotetext{
${ }^{1}$ Karimova Vasila, doctor of psychological Sciences, Professor, Tashkent State Pedagogical University named after Nizami, Tashkent, Uzbekistan.

${ }^{2}$ Mirzabdullaeva Dilxumor, basic doctoral student of Namangan state University, Namangan, Uzbekistan.
} 
Interpersonal conflicts between students and teachers occur in high school. In the lower grades, the teacher for the student is the same unquestionable authority as the parents, so there are no interpersonal conflicts. In adolescence, there is a change in personality, the position of "I am an adult" is defended, which contributes to the creation of conflict situations with the teacher.

In high school, students strive for autonomy, openly defend the right to be themselves, independently solve issues related to them personally, have their own attachments, as well as their own views on what is happening around them. At this age, the reaction to tactless remarks becomes much more acute and can lead to conflicts in any form.

Conflicts between teachers and students may arise due to unfair grades. In such cases, the entire class may become involved in the conflict, acting on the side of the student. Some teachers have two opposite strategies for evaluating students ' knowledge. One is expressed in low requirements for establishing favorable relations with students, the other - in high requirements for the purpose of preparing students for admission to the Institute. Both strategies are potentially conflicting. Overestimated grades discourage good students from active learning, and low grades are perceived by the class as arbitrary behavior of the teacher. A fair assessment of students ' knowledge is required.

Pedagogy is armed with a number of command algorithms that are necessary for the successful work of a teacher:

- the school should only have a working mood, negative emotions related to personal problems remain outside the school:

- do not avoid conflicts, direct the process of their resolution in a constructive direction, do not delay their resolution;

- equal, fair treatment of all students:

* all activities of the teacher are focused on the process of training and education:

- not to humiliate students, but to raise them to their own level:

* teach students the ability to learn:

* demonstrate only assertive behavior in relationships with colleagues.

The word "stress" in English means "tension". This term was introduced into scientific use in 1936 by the outstanding canadian physiologist Hans Selye (b. 1907), who developed the General concept of stress as an adaptive response of the body to the impact of extreme factors (stressogens). The extraordinary popularity of both the concept and its leading concept is probably due to the fact that it can easily explain many phenomena of our ordinary, everyday life: reactions to emerging difficulties, conflict situations, unexpected events, etc.

According to the classical definition Of G. Selye, stress is a non-specific response of the body to any demand presented to it, and this response is a strain of the body aimed at overcoming emerging difficulties and adapting to increased requirements.

The concept of "stress tolerance" has a fairly wide coverage in the scientific literature. Philosophical ideas about stress resistance as the ability to overcome difficulties, resist strong negative influences, suppress and control their emotions that cause high mental tension, have served as the basis for numerous modern theories and concepts of stress and stress resistance. However, there is no generally accepted definition of the phenomenon of stress tolerance. Currently, in psychological science, there is a tendency to describe the ability of a person to maintain optimal functioning of the mind and activity in difficult situations using various terminology categories. This ability is defined as "emotional stability", "neuropsychic stability", "adaptation to stress"and" stress tolerance".

L. M. Abolin includes in this definition parameters that characterize nervous and physical endurance - the ability of a person to successfully solve complex and responsible tasks in a stressful emotional environment without a significant negative impact of the 
latter on the well-being, health and further performance of a person.

Thus, stress tolerance is the ability to maintain effectiveness under stress. Therefore, this is not a" struggle with stress", but an adaptation to it .

The study of professional stress has shown that it is based on the principle established By R. Yerkes and J. Dodson, which is that with an increase in the activity of the nervous system to a certain level, the efficiency of activity increases, but with further activation of the nervous system, the performance indicators begin to decrease. Modern data on the impact of emotional stress on professional activity confirm this position. A review of existing publications indicates that at an average level of emotional stress, a person's performance is quite high, and at low and high levels of emotional stress, they may be worse than the results shown in normal conditions. Stress is an integral part of human existence, you only need to learn to distinguish between the permissible degree of stress and too much stress. It is excessive stress that creates problems for individuals and organizations.

Stress is most common and most pronounced in representatives of the professions of the "person - to-person" system. Today, the profession of a teacher is considered one of the most stressful. Modern research of the problem of stress in the pedagogical sphere (Omarova M. K., Gamzatova H. K., Vasiliev V. G.) proves to us the relevance of the development of such quality as stress resistance. The activity of the teacher is full of various situations that can be a "hotbed" of stress development. And it usually accumulates over a long time. If the impact of the stressor continues for a long time and it is not controlled in any way, then the emotional excitability of the person can take a stable form. Sources of professional stress of a teacher may be related to work, the role of the employee and his relationship in the organization, career, organizational structure and psychological climate of the organization, personal problems of the employee. The causes of stress can be a variety of environmental factors (microbes and viruses, various poisons, high or low ambient temperature, etc.); emotional factors (conflicts in the teaching staff, disrespect of students, unjustified criticism of the chief, etc.).

Professional stress in the activity of teachers, as a rule, is a state of tension that occurs as a result of the impact of adverse factors of professional activity, which subsequently leads to a decrease in the effectiveness of the activity performed, and sometimes deformations of characterological qualities of the individual. Such conditions reduce the quality and success of teachers ' job performance or require additional efforts and conditions to maintain an optimal psychophysiological level, which leads to a number of socio-psychological and socio-economic consequences: reduced job satisfaction and increased staff turnover. All this places the highest demands on the state of morale, professional training, mental health, and psychological training.

Professional activity of teachers takes place in extreme conditions, and they are subject to the phenomenon of emotional burnout. We agree with the definition of I. Y. Mlodik that "emotional burnout" is a phenomenon that is characteristic of those niches where there is constant emotional human contact. Unfortunately, teachers often do not even suspect that fatigue, apathy, and pessimism are symptoms of "emotional burnout" .

Stress resistance is not an innate property of the personality and depends on the level of formation of skills of emotional self-regulation, the impact of the personality on itself in order to bring its own functioning to an optimal state. Research (Omarova M. K.) also proves that stress resistance is determined by a set of personal qualities that allow a person to bear significant intellectual, volitional and emotional loads caused by the characteristics of professional activity, without any harmful consequences for the activities of others and their health. For example, indecision is one of the significant personal qualities associated with exposure to organizational stress. The more indecisive a person is, the more often they avoid responsibility and risk, the lower their stress 
tolerance. The more responsible and conscientious the teacher is about their duties, the more often they have to deal with stressful situations. The level of stress resistance is growing. The higher the level of self-confidence, the easier it is to cope with stress. Internal tension and lack of self-control are closely associated with a reduced level of resistance to stress. The more active an employee is, shows more interest in the activity and is more successful in business, the lower their level of professional stress . Using methods of self-regulation, the teacher is able to freely analyze the situation, maintain a favorable mental state for successful work in difficult emotional conditions. However, it should be noted that the majority of teachers do not know or are not able in any way to relieve stress, emotional tension, increase their own resistance to various negative influences. In the process of impact of a stressful situation on the teacher's personality and reduction of stress resistance as a result of professional activity, it can be argued that the formation of an emotional burnout syndrome.

Thus, it should be concluded that stress tolerance is an important factor in the effectiveness of labor activity, including teaching. A teacher who has a high level of stress tolerance, perceives the problem situations arising in his professional activity not as threatening, stressful, but as situations that require resolution, which stabilizes his professional orientation.

\section{References}

[1] Antsupov A. Ya.. A. I. Shipilov, Conflictology. - Moscow: UNITY, 1999.

[2] Kozyrev G. I. Introduction to conflictology. - Moscow: Vlados, 1999.

[3] Selye H. Stress without distress. - Moscow: 2000.

[4] Trushnikov D. Yu.Konfliktologiya: uchebnik. - Tyumen: TyumGNGU, 2009. - 448 p 


\section{CREATIVITY AS AN INDIVIDUAL'S ABILITY}

\section{Alieva Zulxumor ${ }^{1}$}

\section{Abstract}

This article highlights creativity as a personal ability necessary for modern man. The author explains the indicators of creativity of scientists D. Guilford and E. Torens.

Key words: creativity, ability, personality, indicator.

doi: http://doi.org/10.15350/F_7/25

The concept of creativity comes from the English word "creativity", which means "creation, creation". In psychology creativity is:

* ability to create interesting ideas;

* offer unexpected solutions to problems;

* deviation from the usual thinking algorithms.

Creativity is close in essence to such a concept as creativity, but not identical to it. Creativity involves the process of creating: objects of art, painting, music, literature. Creativity is a special property of a person that allows you to engage in creativity. Thus, a creative person is always creative, this is a mandatory characteristic of her.

A. Maslow, the Creator of the pyramid of needs, believed that at the highest level among the needs and desires of a person is self-actualization-expression outside of the individual traits of the individual. Each of us has something different from other people and only through creativity can we show it to the world.

To act creatively means to act contrary to the established templates and frameworks. The authors of all great and not so great discoveries and inventions are creative people. The first creative was an APE who used a stick instead of a hand to knock a banana off a Bush.

Initially, creativity was considered as a component of intelligence, and in a directly proportional relationship: the higher the creative potential, the higher the intelligence. However, in further research, this theory was not confirmed. High intelligence, i.e. the ability to think logically, smoothly, and on a large scale sometimes even hinders creativity. A person is so confident in their basic knowledge, so logically built a picture of the universe, that it is not possible to go beyond the established templates.

It also happens that a person in the scientific community, who has extensive knowledge and experience, is born with creative ideas, but they can not translate them into reality due to low self-esteem, fear, etc.

The development of creative abilities is based on two things:

1.An individual's understanding of the existing problem and the insufficiency or inconsistency of the resources (knowledge and skills) available to solve it. Special sensitivity to the situation, the presence of frustration.

2.The desire to solve the problem, find a way out, confirm or disprove existing solutions and hypotheses.

Thus, creativity is a phenomenon that is close in meaning to creativity and intelligence, but is a separate concept in psychology. Creative children are considered to be those who do not yet have the attitudes and knowledge that prevent them from approaching the issue creatively.

${ }^{1}$ Alieva Zulxumor, student, Namangan state University, Namangan, Uzbekistan. 
Creativity is inherent in every person from birth. Remember how unconventional young children try to act until they hear the word "not allowed" from their parents. Under the influence of society, some people's creativity disappears completely or is minimized with age.

The parameters of creativity

Today, psychology uses the parameters of creativity proposed by D. Guilford, an American scientist who was actively engaged in the problems of temperament, thinking, and intelligence research.

Guilford identified two types of human thought activity:

* Convergent, in which an individual finds one solution out of a variety of available solutions when solving a problem. There may be several alternatives, but their number is always limited.

* Divergent, characterized in that it goes in different directions, and does not choose from a given set. This type of thinking causes a surprise, not a typical decision.

Individuals with divergent thinking are creative people, they do not solve the problem with known and traditional methods, but resort to searching for them in various directions.

Guilford highlights the following parameters of creativity:

1.The individual is able to find and correctly formulate (put) the problem. A creative person sees the possibility of setting a task where other people do not see it, because they are sure that everything is already known and solved.

2.The ability of a person to give out a large number of new, fresh ideas.

3.The ideas produced are diverse.

4.The presence of originality of thinking. A person appeals to distant associations, has unusual answers to questions, and departs from generally accepted standards.

5.The ability of the individual to add details to a thing or phenomenon, thereby improving them, giving them a new quality, making them suitable for non-traditional use.

6.Ability to analyze and synthesize, logical constructions.

Another famous psychologist E. Torens, developing the theory of Guilford, presented the process of creativity as a chain of five steps:

* The person becomes receptive, sensitive to the appearance of a problem.

* He fixes on the found problem, begins to search for a solution, puts forward hypotheses.

* Various solutions, hypotheses are checked, and modified if necessary.

- At the final stage, the correct solution is found in the given conditions.

Torrence added to the definition of creativity the fact that this phenomenon occurs due to a sense of disharmony caused by the uncertainty (incompleteness) of its activities.

\section{References}

[1] Азарова Н. М.. Креативность как слово и как концепт. // Критика и семиотика, 21 (2014).

[2] Богоявленская Д. Б. Интеллектуальная проблема творчества. Ростов-на-Дону, 1983.

[3] Богоявленская Д. Б. Психология творческих способностей. М.: «Академия», 2002.

[4] Дружинин В. Н. Диагностика общих познавательных способностей. - М.: «ИП РАН», 1997.

[5] Дружинин В.Н. Проблемы общих способностей (интеллект, обучаемость, креативность) - СПб.; Питер,2007.

[6] Льюис, Гарет. Как развить креативность за 7 дней. - М.: Издательство "Э", 2018. - 128 с. — ISBN 978-5-04-091600-9. 


\section{FEATURES OF THE FORMATION OF THE PEDAGOGICAL IMAGE IN THE DEVELOPMENT OF THE TEACHER'S PERSONALITY}

\section{Juraeva Sarvinoz ${ }^{1}$}

\section{Abstract}

The article widely covers the interdependent features of pedagogical image, method and skills that are vital for a tutor.

Key words: pedagogical image, pedagogical method and skills, personality of a teacher, pedagogical imagination, self-education.

doi: http://doi.org/10.15350/F_7/26

The teacher is the main organizer of the educational process. New programs in all systems of continuing education, introduced in the context of growing science and technology, increasing the economic and cultural level of the country, place much higher demands on teachers. Loving the teaching profession is one of the necessary conditions for creating your own pedagogical style. Only a person who loves his profession will devote all his energy, heart and heart to this work and will have his own style, creating a unique pedagogical image in the process of his activity. Pedagogical work on the upbringing of the younger generation requires special organization and the presence not only of certain skills and abilities, but also a number of mental characteristics that belong to the category of pedagogical abilities.

It is known that the main qualities of a teacher with a unique image and style, which develops in the process of continuing education, are as follows.

- A teacher who educates and educates the younger generation, first of all, should be distinguished from others by his broad outlook, high level of ideological and political beliefs. Only a teacher who has dedicated his life to the people, to his country, can do his job properly.

- A love for children, pedagogical work, a willingness to work and be with the children's team is an absolutely necessary condition for successful educational work. A teacher's love for children is expressed in his sincere satisfaction with the opportunity to enter into the world of children, in a simple and sincere relationship with children.

In pedagogical educators, that is, educators with a unique style, his unique abilities, pedagogical etiquette and delicacy also show the peculiarities. The so-called pedagogical abilities characterize both the mental and the emotional-volitional side of the educator's personality, which has a unique image. All of these qualities are interconnected, interact with each other, and form a whole. They must have academic, didactic, perceptual, speech, organizational, authoritarian, communicative and similar skills, which are characteristic of teachers who have a unique style and are able to form their own pedagogical image. At the same time, the role of pedagogical imagination in the formation of pedagogical style is important.

Pedagogical imagination is a special ability that is expressed in anticipating the consequences of one's actions, in cultivating a person connected with the student's vision of what kind of person he will be in the future, in predicting what qualities the pupil will develop. This ability is associated with pedagogical optimism, the power of education, trust in the person.

${ }_{1}$ Juraeva Sarvinoz, NamSU, student of the Faculty of Foreign Languages and Literature. 
The success of pedagogical influence in a teacher who is able to create a unique pedagogical image depends in many respects on the acquisition of pedagogical etiquette. Pedagogical etiquette means that the teacher treats students well, cares for them, makes reasonable demands on them, and respects human dignity in students. In short, pedagogical etiquette is a sense of norm in the pedagogical influence on students.

There is also another important factor, which is pedagogical tact. Pedagogical tact (tact) is characterized as a measure, norm and limit of the means of influence of the teacher in accordance with the pedagogical purpose, useful, valuable actions. The mentioned components of pedagogical skills enrich the professional characteristics of the teacher and lead him to mastery, and help the teacher-educator to form the skills of pedagogical skills. However, relying on them alone to become a master of their profession may not yield the expected result. This requires regular pedagogical thinking, pedagogical thinking, pedagogical work.

Interest in the teaching profession plays an important role in the development of unique pedagogical skills. In fact, these precious qualities in man are inextricably linked. depends on. An activity performed with interest, no matter how complicated it may be, even if it fails, gives a person great inner satisfaction, satisfaction. The broader and deeper the teacher's knowledge, the greater the desire to impart that knowledge to the students. Such a teacher is the best educator, many of whom remain masters of their subject, Methodists. The sum of all the spiritual qualities that enable a teacher to communicate well with children ultimately leads to the reputation of the teacher in the eyes of the students, which is extremely important for the success of educational work. A teacher who is respected in the eyes of students is a reputable educator. The educator has a strong and quick influence on children because of his reputation. A teacher gains a reputation in the eyes of children for his diligence, knowledge, and behavior.

In order for a teacher to educate himself, he must first study himself in depth, be able to see the successes and shortcomings of his work. Self-study is also necessary to understand the other person. It is impossible to study oneself as a person without learning other people and comparing oneself with others. Self-awareness, a feature of self-esteem, is formed in the process of interaction with other people, during joint activities. First of all, the teacher must learn what qualities of pedagogical ability he has, and pedagogical ability, for example, is manifested in the fact that the teacher loves pedagogical activity, that is, people and others, has the necessary patience. Many teachers consider themselves worthy of pedagogical activity and go down this path of activity.

In short, if a teacher is not satisfied with his work, if his work does not bring him joy, if raising a human child is not his life goal, he should think about how well he has chosen this profession. It helps to solve this problem correctly, to be able to correctly assess one's own qualities, one's own capabilities.

An advanced teacher always seeks to keep abreast of pedagogical innovations, uses the experiences of other teachers, and generalizes his or her own personal experiences.

\section{References}

[1] Хўжамуродов И. Ма`навий қадриятлар ва миллий ўзликни англаш Тошкент. 1991 й. 3439 б

[2] Реан А.А. Коломинский П.Я. Социальная педагогическая психология М. 2004 . 234 с.

[3] Э. Гозиев. Психология. -Т. 1992 й.72б 


\title{
METHODS OF PREPARING CHILDREN FOR SCHOOL IN FINE ACTIVITIES
}

\author{
Abdullaeva Masuda ${ }^{1}$ \\ Abdullaev Dilmurod ${ }^{2}$
}

\section{Abstract}

In the article is described the preparation of children for school and the formation of the necessary knowledge and skills among them through conducting fine arts.

Key words: visual arts, school, training, children, knowledge, skills and formation.

doi: http://doi.org/10.15350/F_7/27

Preparing children for school is a very complex process and requires parents to know a lot. It is known that from the moment a child regains consciousness, he becomes very fond of drawing in the right place with what he can get his hands on. Our task is to direct these aspirations and interests in children in the right direction. It makes sense to prepare children for the visual arts from an early age. Because the earlier children engage in goal-oriented activities, the sooner they will have the necessary experiences.

Now there is a problem of preparing children for school through specially designed classes so that there is no sharp difference between a child brought up in a neighborhood who is unprepared for school and children from kindergarten. This, in turn, creates the need to develop a number of manuals and guides for parents, visual aids. We now need to show such training on television in order to facilitate the work of parents. The purpose of these shows is to teach parents, adults, and children to use the most convenient ways to prepare children approaching school age for school. If children are not engaged in visual activities on a regular basis, they will first need to be taught to perform tasks that are structurally simple. These instructions show some examples of such simple tasks. Children will be shown colored pencils, paper, brushes, colored paper, watercolors. In the first lesson, children are introduced to colored pencils and how to work with them. The pen shows the methods of drawing straight, oblique, oblique, ring lines.

"Rain" The purpose of drawing this picture is to teach children to draw slash-andslash lines. To do this, children will need to hold a pencil and draw lines (the order of drawing lines is shown in practice). Here is a visual aid to help children learn how to draw straight lines. (a picture of an adult working is shown). "Let's draw colored threads." This picture is very useful in teaching children to draw lines that are much longer from top to bottom. Children are encouraged to run their fingers through the surface of the yarn to test how straight it is. Then the pencil shows the order of drawing straight lines. A visual weapon made of cardboard will be on display. "Drawing colored sticks" In the process of drawing this picture, children learn to draw straight lines from top to bottom. The methods of using watercolor paint in the processing of this picture will be demonstrated to children in practice. Let's take a closer look at the pencils with the kids. Then we show in a practical way the order in which his image is processed. It is preferable to use gouache

\footnotetext{
${ }^{1}$ Abdullaeva Masuda, Associate Professor of Preschool Education, Candidate of Pedagogical Sciences, Namangan State University.

${ }^{2}$ Abdullaev Dilmurod, Lecturer, Namangan State University.
} 
in four different colors when working on these pictures (a picture of cuttings made of colored gouache is shown).

- Bagel. The purpose of drawing this picture is to teach children to draw things in the shape of a circle. In this case, the children first draw a circle and draw a picture of the second ring, which is smaller than the middle. The result is a two-line perforated picture. Now you can paint between these lines. The order in which the hole cake is drawn is practically shown. -Apples are big and small|| Once the children have learned to draw pictures of round-shaped objects, we move on to describe the large and small views of the apple. In doing so, children learn to describe things that are more interesting with the help of what they have learned.

The children are shown the order of drawing pictures of big and small apples in practice. It describes different types of aircraft. The children are shown pictures of the planes and the drawing procedure is practically explained. Children can make pattern pieces by following them. The children will be shown samples of the finished work and explained the procedure for drawing them. -Fish in the aquarium $\|$ The children watched a lot of fish swimming in the aquarium. Now they are also working on color pictures of these fish. To do this, take a sheet of medium-sized paper and draw a ball or a rectangular aquarium picture on its surface. It depicts fish and algae swimming in the water. The children are shown examples of such pictures.

The procedures for drawing them are explained in practice. To further enrich children's understanding, the image of fish cut from colored paper can be displayed on the surface of the paper depicting the aquarium in different situations. Preschoolers have developed mechanical memory and do not have difficulty learning other languages quickly. "How should a preschooler be prepared" raises an important question. The main thing is to form him a certain level of psychological readiness, interest in learning, self-control skills, communicative and creative abilities, speech, memory, attention, thinking. We see that the preparation of children for school should begin not on the basis of large or preparatory groups, but on the day of his arrival at the preschool. To be more precise, it should be started earlier, because just as it is difficult to make a child attentive, curious, independent, it is difficult to teach him to solve some problems together in a short time.

First of all, in the process of preparation for school, it is necessary to change the direction of educational activities. At this stage in the formation of the child's thinking, the developmental components should take precedence over the meaningful components. The services of methodologists and teachers of preschool education should be aimed at directing each child to the activity, to be able to analyze the characteristics of objects and events, that is, to distribute subjects according to the specified sign, to distinguish differences and common features. How to prepare children for school?

1. Make sure your child attends preschool wholeheartedly.

2. Make demands on your child, taking into account age-specific norms and age characteristics.

3. Strive for the child to feel your affection through actions and words.

4. Create conditions for him in the family.

5. Always support the same, but even more so. Because the difficulties of the period of adaptation to school await him.

6. Know the level of maturity specific to school age and try to shape them in a timely manner.

7. Create conditions for mental development, try not to lag behind. 


\section{DEVELOPMENT OF PSYCHOLOGICAL FEATURES OF ATTENTION AT JUNIOR SCHOOL-AGE}

Abdullaeva Nilufar ${ }^{1}$

\section{Abstract}

This article discusses the development of psychological features of attention at junior school-age.

Key words: small school age, student, attention, development, feature.

doi: http://doi.org/10.15350/F_7/28

It is well known that our future is a child in the hands of the younger generation. Today, at the initiative of President Shavkat Mirziyoyev, children, especially in kindergarten and primary school, are being treated at the level of state policy.

In particular, the application of various interactive methods and innovative methods to the younger generation in schools and preschools is a very responsible task facing every educator today.

At a time of rapid development today, one of the major challenges facing every educator is how to draw students 'attention to the activity being taught and how to direct their attention to the lesson process correctly and effectively. Due to the speed of information exchange, today the attention of young people is quickly distracted and distracted by any news.

The child's small school age period corresponds to the school years in the primary grades. Before moving from play to reading, the child is psychologically and physically ready for the most important period of his life, that is, to meet the various requirements set by the school, in other words, to get an education. The number of actions in this regard requires a great deal of knowledge and skill from the teacher. In addition, the teacher should not distract the student with any peculiarities. In some cases this is one of the important tasks to be carried out by teachers and pedagogical staff

It is also advisable to ask the teacher to control the children's thoughts and play various games with them.

The sharpness and purity of the child's perception at this age, his curiosity and the brilliance of his imagination are well known. This can be clearly seen in his play, in his drawing, in his work of making things out of clay and plasticine, in his simple construction work. At this time, the child's memory is also sufficiently developed and strong. The child will be able to easily and firmly remember things that are directly related to their interests. He knows from experience that in order to remember something well, he has to repeat it several times. However, the effectiveness of memorizing the meaning will be slightly lower.

Younger school-age students also have a greater interest and passion for socially useful work, and a tendency to engage in physical behaviors and exercises while imitating adults. It is obvious that the child will also develop physiological opportunities for school education.

This means that our child has the opportunity to receive a school education in all respects, both psychologically and physiologically. Therefore, in order to form the next

${ }^{1}$ Abdullaeva Nilufar, Basic doctoral student of Namangan State University. 
knowledge, skills, abilities of students, they really need to develop psychological aspects in order to grow their consciousness. Here, children's attention, thinking are the most important psychological processes.

In a child who has just entered school, the first type of attention - involuntary attention - predominates. It can be observed that his attention is rapidly divided, distracted, unable to hold himself in one place. Showing the child what is important and interesting to him or her at such a time will increase the child's attention to the shape, appearance, location, size, difference, and color of these objects. Now the child will be able to hold his consciousness at one point in relation to the object while studying it carefully. As a result, he learns how this thing serves for numa, how it is used. It is such activities that also help for the development of a child's memory. To do this, of course, we use psychological exercises and trainings. Below we show an attention-building exercise and the procedures for conducting it.

1. EXERCISE.1. We show the reader a picture of a group of wild animals at the same time. We ask them to distinguish which of them are birds, which are predators, and which are reptiles. Then we ask where these animals live and what they eat, and we encourage them to develop their thinking.

CONCLUSION: Any small school-age student, whether a boy whether it is a girl or a boy, he is definitely interested in wild animals and this thing attracts them. As a result, the reader's mind is focused on one point and is encouraged to think, at least in part.

2.EXERCISE 2. We show the reader a number of things with 3-4 toys in them at a time. Naturally, 3-4 toys in things quickly attract the attention of a small school-age child. Yes if toys are everywhere 


\section{CHARACTERIZATION OF THE PROCESS OF EDUCATION OF PATRIOTISM AMONG STUDENTS OF HIGHER EDUCATIONAL INSTITUTIONS}

\section{Abdullaev Amrillo ${ }^{1}$}

\section{Abstract}

This article talks about the characteristics of the process of education of patriotism among students of higher educational institutions.

Key words: patriotism, moral and social feeling, spiritual education, sociocultural situation, military-patriotic activity.

doi: http://doi.org/10.15350/F_7/29

Патриотизм - это интегративное личностное качество включающее в свою структуру наряду с деятельностным и гностическим компонентами, нравственное и социальное чувство, чувство безмерной любви к своему народу, гордости за него, переживание за его успехи и горечи, за победы и поражения. Патриотизм далеко не всегда пробуждает в человеке чувство Родины, тем более, когда отсутствует сам фундамент патриотического воспитания. Задача системы национального духовного воспитания - тактично и чутко пробудить и формировать в человеке настоящий патриотизм. Не навязывать и проповедовать, а побуждать и доказывать делами. Патриотизм не может быть заимствован и обряжен в чужие обноски, он вырабатывается исторически, всей жизнью народной, в том числе в борьбе с чужими, а потому всегда самобытен. Идея формирования патриотической культуры у студентов военного факультета является не просто отображением тенденции развития современного общества, но и стимулирует поиск способов и средств формирования патриотической культуры в процессе военно-патриотической подготовки. Современное представление о процессе формирования патриотической культуры у студентов складывается на основе теоретических и экспериментальных исследований процесса военно-патриотической подготовки будущих офицеров:

1. Главным при определении содержания обучения студентов в современной социокультурной ситуации является реализация ее гуманистической функции, что выражается способностями будущих военных специалистов к трансляции своего патриотического опыта подчиненным. Однако налицо противоречие между потребностью общества в военных специалистах, готовых к защите своего Отечества и трансляции своего патриотического опыта подчиненным, и существующей практикой формирования патриотической культуры студентов военного факультета.

2. Исторический опыт подготовки офицеров убеждает, что каждый его этап характеризуется особыми целями и средствами достижения образовательного результата. Вместе с тем, суть стратегии военно-патриотической подготовки должна заключаться в сохранении преемственности ее осуществления на основе любви к Отечеству, народу, культуре, что в армейских условиях будет выражаться воинским долгом, мужеством, ответственностью при защите национальных интересов Родины.

3. Организация военно-патриотической подготовки будущих офицеров в военном факультете должна базироваться на комплексном подходе, предполагающем взаимосвязь основных направлений по созданию условий, обеспечивающих потребности армии и общества в воспроизводстве и приращении интеллекта и культуры: первое направление - повышение роли и эффективности гуманитарных дисциплин; второе - усиление патриотической составляющей учебно-воспитательного процесса. Базис для успешной военно-патриотической деятельности созда-

\footnotetext{
${ }^{1}$ Abdullaev Amrillo, Master student, Bukhara State University, Uzbekistan.
} 
ется интегративным подходом, требующим единства гуманитарных, психолого-педагогических и военных дисциплин, сквозного объединения традиционных и активных методов в рамках гуманистической парадигмы военного образования.

4. Новая социальная ситуация, когда прежние подходы к рассмотрению самой идеи патриотизма устарели, требует внесения изменений в содержание военно-патриотической подготовки будущих офицеров и поиска способов возрождения уважительного отношения к отечественной истории, культуре, военным традициям.

В этих условиях представляется оправданным определение такой новой категории дидактики, как «патриотическая культура», отражающая нормативное знание о требуемом уровне военного образования, целью которого является формирование патриотической культуры будущих офицеров. Структура патриотической культуры, выражая диалектическую взаимосвязь культуры и патриотизма, должна представляться согласно принципу детерминизма чувственно-эмоциональным, когнитивным и деятельностным компонентами.

5. Повышению уровня патриотической культуры студентов и, как следствие, качества военно-патриотической подготовки выпускников военного вуза будут способствовать специально отобранные содержание, формы и методы, представленные мотивационно-целевым, содержательно-операционным, операционно-управленческим, диагностическим блоками системы формирования патриотической культуры студентов, отражающими связь между требованиями социальной среды к уровню военного образования и личным устремлением студентов.

Стратегия деятельности преподавателя вуза по формированию патриотической культуры студентов заключается во внедрении в учебно-воспитательный процесс содержания, стимулирующего развитие патриотических чувств, чести, достоинства, долга, способностей к моральной рефлексии, к оцениванию сложившихся отношений между субъектами военно-патриотической деятельности, способностей транслировать свой патриотический опыт подчиненным. Главным при освоении содержания становится полнота отношений, в которые включаются студенты для овладения репертуаром решений военно-патриотических задач, имитируемых игровыми и тренинговыми формами обучения, в ходе встреч с участниками военно-боевых действий, в период войсковых стажировок.

6. Военно-патриотическая подготовка, суть которой выражается сфор-мированностью патриотической культуры, будет эффективной, когда средства учебно-воспитательного процесса ориентированы на реализацию в учебном процессе вуза субъект-субъектных отношений между преподавателями и студентами; определяющую роль при этом приобретают психолого-педагогические приемы формирования патриотической культуры, отношения между преподавателями и студентами, основанные на паритетных началах и обеспечивающие существование обучающихся как субъектов деятельности. Организация совместной деятельности предполагает несколько этапов (целеполагания, информационно-аналитический, организационно-методический, этап исполнения), раскрывающих особенности организации деятельности преподавателей и студентов по формированию патриотической культуры и показывающих роль, отводимую каждому из субъектов. Возможность изменения общности обучения на разных его этапах образует движение от зарождения общности смыслов, целей и способов деятельности к развитию единого смыслового поля, в котором начинает дифференцироваться, оформляться новая социально-обусловленная индивидуальная форма саморегуляции деятельности. В итоге высокий уровень показателей компонентов патриотической культуры является критерием ее сформированности.

\section{References}

[1] Абдулатипов, Р.Г. Человек. Нация. Общество / Р.Г. Абдулатипов. -М.: Политиздат, 1991. $224 \mathrm{c}$.

[2] Абульханова-Славская, К.А. Стратегия жизни / К.А. Абульхано-ва-Славская. М. : Мысль, 1991. - 299 c. 


\title{
EDUCATION OF MORAL PRINCIPLES OF PRESCHOOL CHILDREN
}

\author{
Gulbakhor Davronova ${ }^{1}$ \\ Nigina Ikramova ${ }^{2}$
}

\section{Abstract}

This article analyzes the upbringing of the moral principles of preschool children.

Key words: humane, benevolent attitude, moral norm, benevolence, responsiveness, sense of community, lack of value.

doi: http://doi.org/10.15350/F_7/30

Проблема воспитания гуманных, доброжелательных отношений в группе дошкольников стояла перед педагогами всегда. Практически все образовательные программы для детей дошкольного возраста содержат раздел «социально-эмоциональное» или «нравственное» воспитание, посвященный формированию положительного отношения к другим людям, социальных чувств, просоциальных действий, взаимопомощи и пр. Важность этой задачи очевидна, поскольку именно в дошкольном возрасте складываются основные этические инстанции, оформляются и укрепляются индивидуальные варианты отношения к себе и к другому. Вместе с тем методы такого воспитания не столь очевидны и представляют собой серьезную педагогическую проблему.

Наиболее распространенным методом формирования социальных и нравственных чувств являются осознание эмоциональных состояний, своеобразная рефлексия, обогащение словаря эмоций, овладение своеобразной «азбукой чувств». Основным методом воспитания нравственных чувств как в отечественной, так и в зарубежной педагогике являются осознание ребенком своих переживаний, познание себя и сравнение с другими. Детей учат рассказывать о собственных переживаниях, сравнивать свои качества с качествами других, распознавать и называть эмоции. Однако все эти приемы концентрируют внимание ребенка на самом себе, своих достоинствах и достижениях. Детей учат прислушиваться к себе, называть свои состояния и настроения, понимать свои качества и свои достоинства. Предполагается, что ребенок, уверенный в себе, хорошо понимающий свои переживания, легко может встать на позицию другого и разделить его переживания, но эти предположения не оправдываются. Ощущение и осознание своей боли (как физической, так и душевной) далеко не всегда приводит к сопереживанию боли других, а высокая оценка своих достоинств в большинстве случаев не способствует столь же высокой оценке других.

В этой связи возникает необходимость новых подходов к формированию межличностных отношений дошкольников. Основной стратегией этого формирования должна стать не рефлексия своих переживаний и не усиление своей самооценки, а, напротив, снятие фиксации на собственном Я за счет развития внимания к другому, чувства общности и сопричастности с ним. Такая стратегия предполагает существенную трансформацию ценностных ориентиров и методов нравственного воспитания детей, существующих в современной дошкольной педагогике.

\footnotetext{
${ }_{1}^{1}$ Gulbakhor Davronova, undergraduate, Bukhara State University, Uzbekistan.

${ }^{2}$ Nigina Ikramova, student, Bukhara State University, Uzbekistan.
} 
В последнее время формирование положительной самооценки, поощрение и признание достоинств ребенка являются главными методами социального и морального воспитания. Этот метод опирается на уверенность в том, что раннее развитие самосознания, положительная самооценка и рефлексия обеспечивают эмоциональный комфорт ребенка, способствуют развитию его личности и межличностных отношений. Такое воспитание направлено на подкрепление положительной самооценки ребенка. В результате он начинает воспринимать и переживать только самого себя и отношение к себе со стороны окружающих. А это, как было показано выше, является источником большинства проблемных форм межличностных отношений. Такая фиксированность на себе и собственных качествах закрывает возможность увидеть другого. В результате сверстник зачастую начинает восприниматься не как равный партнер, а как конкурент и соперник. Все это порождает разобщенность между детьми, в то время как главной задачей нравственного воспитания является формирование общности и единства с другими. Стратегия нравственного воспитания должна предполагать отказ от конкуренции и, следовательно, оценки. Любая оценка фокусирует внимание ребенка на собственных положительных и отрицательных качествах, на достоинствах и недостатках другого и в результате провоцирует сравнение себя с другими. Все это порождает желание угодить взрослому, самоутвердиться и не способствует развитию чувства общности со сверстниками. Несмотря на очевидность этого принципа, его сложно выполнить на практике. Поощрения и порицания прочно вошли в традиционные приемы воспитания.

Необходимо также отказаться от соревновательного начала в играх и занятиях. Конкурсы, игры-соревнования, поединки и состязания весьма распространены и широко используются в практике дошкольного воспитания. Однако все эти игры направляют внимание ребенка на собственные качества и достоинства, порождают яркую демонстративность, конкурентность, ориентацию на оценку окружающих и в конечном итоге -- разобщенность со сверстниками. Именно поэтому для формирования нравственного начала важно исключить игры, содержащие соревновательные моменты и любые формы конкурентности.

Таким образом, воспитание нравственных чувств на первых этапах должно базироваться на следующих принципах:

1. Безоценочность. Любая оценка (независимо от ее валентности) способствует фиксированности на собственных качествах, достоинствах и недостатках. Именно этим обусловлен и запрет на любое вербальное выражение отношения ребенка к сверстнику. Минимизация речевых обращений и переход к непосредственному общению (экспрессивно-мимическим или жестовым средствам) может способствовать безоценочному взаимодействию.

2. Отказ от реальных предметов и игрушек. Как показывает практика, появление в игре любого предмета отвлекает детей от непосредственного взаимодействия. Дети начинают общаться «по поводу» чего-то и само общение становится не целью, а средством взаимодействия.

3. Отсутствие соревновательного момента в играх. Поскольку фиксированность на собственных качествах и достоинствах порождает яркую демонстративность, конкурентность и ориентацию на оценку окружающих, мы исключили игры, провоцирующие детей на проявление данных реакций.

Главная цель нравственного развития заключается в формировании общности с другими и возможности видеть в сверстниках друзей и партнеров. Чувство общности и способность увидеть другого являются тем фундаментом, на котором строится нравственное отношение к людям. Именно это отношение порождает сочувствие, сопереживание, сорадование и содействие. 
Исходя из этих положений, главной задачей игр для детей 4-6-летнего возраста является привлечение внимания ребенка к другому и его различным проявлениям: внешности, настроениям, движениям, действиям и поступкам. Предлагаемые игры помогают детям пережить чувство общности друг с другом, учат замечать достоинства и переживания сверстника и помогать ему в игровом и реальном взаимодействии.

1.Основной задачей первого этапа в игре является отказ от речевых сnособов общения, столь привычных для детей, и переход к жестовым и мимическим средствам коммуникации, которые требуют большего внимания к другим. На втором этапе внимание к сверстнику становится смысловым центром всех игр. Подстраиваясь к другому и уподобляясь ему в своих действиях, дети учатся замечать самые мелкие детали движений, мимики, интонаций своих ровесников. На третьем этапе отрабатывается способность к согласованности движений, что требует ориентации на действия партнеров и подстройки к ним. Четвертый этап предполагает погружение детей в общие для всех переживания -- как радостные, так и тревожные. Создаваемое в играх мнимое чувство общей опасности объединяет и связывает дошкольников. На пятом этапе вводятся ролевые игры, в которых дети оказывают друг другу помощь и поддержку в трудных игровых ситуациях. На шестом этапе становится возможным вербальное выражение своего отношения к сверстнику, которое по правилам игры должно иметь исключительно положительный характер (комплименты, добрые пожелания, подчеркивание достоинств другого и пр.) И наконец, на заключительном, седьмом этапе проводятся игры и занятия, в которых дети оказывают друг другу реальную помощь в совместной деятельности.

\section{References}

[1] Кравцова Е.Е. Психологические новообразования дошкольного возраста // Вопр. психол. 1996. №6. 


\title{
IMPORTANT ASPECTS OF PEDAGOGICAL SKILL AND WAYS OF ITS FORMATION
}

\author{
Ochilova Manzura ${ }^{1}$ \\ Rakhimova Nilufar ${ }^{2}$
}

\section{Abstract}

This article presents important aspects of pedagogical skills and methods of its formation.

Key words: pedagogical skills, professional knowledge, humanism, abilities, communication skills, perceptual abilities, dynamism, emotional stagnation, creativity.

doi: http://doi.org/10.15350/F_7/31

Har tomonlama yetuk, o`z kasbining ustasi, yuksak mahoratli pedagog kadrlarni tayyorlash davlat ta lim siyosatining ustuvor yo`nalishlaridan biridir. V.A. Suxomlinskiy o`zining "Chin insonni qanday tarbiyalash kerak" nomli asarida o`qituvchining mehnatini biror narsa bilan qiyoslab ham, taqqoslab ham bo'lmaydi, - deb ta'kidlab o'tadi. Shuningdek, to`quvchi bir soatdan keyinroq o`z ishining hosilini ko`radi, po`lat erituvchi bir necha soatdan keyin olovdagi metall oqimidan shodlanadi. Bu uning orzusini yuksak cho`qqisi. Yer haydovchi, don sepuvchi, g`allakor bir necha oydan so`ng dalada o`stirgan boshoqlari va bir siqim donidan zavqlanadi. O`qituvchi esa o`z ijodining mahsulini ko`rish uchun yillab mehnat qilishi kerak. O`qituvchi har bir soat, har bir daqiqada o`zining o`ttizta yoki qirqta tarbiyalanuvchisidan har birini ko`rib turishi, u shu daqiqada nimalar o`ylayotganligini, qanday g`am-alamlar uni tashvishlantirayotganligini bilishi kerak, - degan fikrlarni bayon etadi.

Pedagogik mahorat-kasbiy pedagogik faoliyatni yuqori darajada tashkil etishni ta'minlovchi shaxsiy xususiyatlar yig'indisi bo'lib, uning elementlari:

1.Kasbiy bilim, fanlarni o'qitish metodikasi, pedagogika va psixologiya.

2.Insonparvarlik yo'nalishi - qiziqishlar, oliy maqsad, boyliklar.

3.Pedagogik qobiliyat - kommunikativlik, pertseptiv qobiliyat, dinamizm, emotsional turg'unlik, optimistik tarzda oldindan ko'ra bilish, kreativlik.

4. Pedagogik texnika - o'zini boshqarishni, o'zaro ta'sir mexanizmini bilish. iboratdir.

5. Kommunikativlik-odamlarga yaqinlik, samimiylik, xushmuomalalikdan

Pedagogik mahoratning asosiy negizi bu - kasbga oid bilimlarni puxta o`zlashtirishdan iboratdir. O`qituvchi o`quv yurtidayoq ilmiy bilimlar tizimini puxta egallab olishi kerak. Pedagogik mahoratni egallashda psixologiya va pedagogika faniga doir bilimlar katta rol o`ynaydi. Ilmiy psixolgik va pedagogik bilimlar sistemasining mavjudligi o`qituvchiga faqat o`z sinfini hamda ayrim o`quvchilarni o`rganish va ularning to`g 'ri fe`latvorlarini tushunishgagina emas, balki bolalar jamoasi va uning har bir a`zosini rivojlanish istiqbolini ham belgilash imkonini beradi.

Muvaffaqiyatli ishlash uchun har bir o`qituvchi pedagogik mahoratga ega bo lishi lozim. Pedagogik mahorat egasiz mehnat sarf qilib, katta natijaga erishadi. Ijodkorlik hamisha uning hamkori bo 'ladi. Pedagogik ishga qobiliyatli, iste`dodli kishidagina pedagogik mahorat bo 'lishi mumkin. Qobiliyat esa faoliyat jarayonida paydo bo ladi va rivojlanadi. Qobiliyatli va mahoratli o`qituvchi oldida esa hozirgi kun talabi asosida vatanimiz

\footnotetext{
${ }^{1}$ Ochilova Manzura, Lecturer, Bukhara State University, Uzbekistan.

${ }^{2}$ Rakhimova Nilufar, Lecturer, Bukhara State University, Uzbekistan.
} 
ravnaqi uchun xizmat qila oladigan, o`z vatanini dildan sevadigan va bu yo`lda o`z jonini ham ayamaydigan yoshlarni vatanga mehr-muhabbat ruhida tarbiyalash vazifasi turadi.

Respublikamizda qabul qilingan "Ta’lim to 'g`risida"gi Qonun va Kadrlar tayyorlash milliy dasturi o`qituvchilar oldiga juda katta va mas`uliyatli vazifalarni yukladi. Davlat ta`lim siyosatida belgilab berilgan vazifalarni ro`yobga chiqaruvchi o`qituvchilardan o`z ustilarida muntazam ishlashni, o`z shaxsiy va pedagogik mahoratini yuksak darajada rivojlantirib borishini talab etadi.

Pedagogik mahorat o`qituvchidan quyidagilarni talab etadi:

1. O`qituvchining dunyoqarashi keng bo`lib, hamma voqea, hodisa ustida erkin fikr yurita olishi zarur.

2. 0`qituvchi birinchi galda o`zi o`qitadigan fanni chuqur egallagan bo`lgandagina, o`quvchilarda umumiy va kasbiy ta`lim sifatini tarbiyalay oladi va ularda fan-texnika hamda amaliy faoliyatga qiziqish va istak hosil qila oladi.

3. O`qituvchi hozirgi zamon fan-texnika talabiga muvofiq yaxshi dars berishi va uning har daqiqasidan unumli foydalanishi zarur.

4. U yaxshi o`qituvchi bo`lishi uchun pedagogika, psixologiya va o`z fanining metodikasini ham yaxshi bilmog i lozim.

5. O`qituvchining umumiy madaniyati yuqori bo 'lishi bilan birga bu kasb adabiyot va san`at sohasidagi bilimlarga ega bo`lishni talab etadi.

6. O`qituvchi pedagoglik odobiga rioya qilishi kerak. Pedagoglik odobi o`qituvchilik kasbiga xos fazilatlardan bo 'lib, u o`qituvchining bolalar bilan ishlashi jarayonida uning tajribasi mahorati oshadi.

7. O`qituvchi pedagoglik mahoratiga va har tomonlama bilimga ega bo'lishi kerak, chunki unga o`quvchilar har sohada murojaat qilishlari munkin.

Pedagogik mahorat o'z navbatida o`qituvchidan o`ziga xos qobiliyatlar majmuasini talab etadi. Qobiliyatlar bilim, ko`nikma va malakalarni egallashda namoyon bo`lsa ham bilim va ko`nikmalarni egallash bilangina bog`lanib qolmaydi.

Insonni har tomonlama mukammal tarbiyalash, uning kelajagini belgilash borasida tarbiyachi pedagog mahorati, uning yetukligi, chuqur kasbiy bilimi, ko'nikma va malakasi, maxsus bilim, tajriba muhim rol o'ynaydi, ayniqsa o'quvchi ehtiyoji va e'tiqodini, uning qobiliyati va amaliy ko'nikmalarini mahoratli pedagogsiz shakllantirish mumkin emas. Bunda esa o'qituvchida pedagogik mahorat.

\section{References}

[1] Farberman B.L. Ilg'or pedagogik texnologiyalar. T.:1999.

[2] Azizxo'jaeva N. N. Pedagogik texnologiya va pedagogik mahorat. T.: 2003 


\section{MEDICAL SCIENCES}

\section{THE PROBLEM OF COMORBIDITY IN ACUTE CORONARY SYNDROME WITHOUT ST SEGMENT ELEVATION}

\section{Grebenchikova Ekaterina ${ }^{1}$ \\ Cherepanova Ekaterina ${ }^{2}$}

\section{Abstract}

The elevation of waterballst patients after acute coronary syndrome without lifting of segment ST through the analysis of case histories. The most common concomitant pathology, as well as the main complications encountered in this disease, were identified. Key words: acute coronary syndrome without ST segment elevation, comorbidity, percutaneous coronary intervention.

doi: http://doi.org/10.15350/F_7/32

Актуальность: Сердечно-сосудистые заболевания являются основной причиной смерти во всем мире. По данным Всемирной организации здравоохранения ежегодно число летальных исходов по причине болезней системы кровообращения составляет более 17 миллионов человек. [3] Несомненным «пусковым механизмом»в прогрессировании данной патологии являются факторы риска, рассматриваемые в системе кардио-васкулярного континуума. Следовательно, наличие коморбидной патологии у пациента является ведущей проблемой современной медицины. [1] Особый интерес с позиции коморбидности представляет ОКС, для которого, несмотря на организационные и терапевтические меры, по-прежнему характерны высокая распространенность и смертность во всем мире. [2]

Цель: изучить взаимосвязь коморбидных состояний с риском развития ОКС без подъема сегмента ST.

Материалы и методы: В 2019 году на базе ГБУЗ ПК «ГКБ №2 им. Ф.Х. Граля» проанализировано 35 историй болезни пациентов, госпитализированных в кардиологическое отделение по поводу ОКС без подъёма сегмента ST, выявлены основные коморбидные патологии, проанализированы результаты коронароангиографии, холтеровского мониторирования ЭКГ, основные лабораторные показатели.

Полученные результаты: В результате обработки историй болезни выявлено, что из 35 пациентов мужчины составляют 11 человек (31\%), женщины

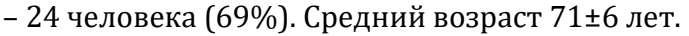

Установлено, что коронароангиография проведена у 14\% пациентов, причём в 80\% случаев выявлен критический стеноз коронарных артерий. Основным методом лечения является медикаментозная терапия, которую

\footnotetext{
${ }^{1}$ Grebenchikova Ekaterina, Perm State Medical University, Russia.

${ }^{2}$ Cherepanova Ekaterina, Perm State Medical University, Russia.
} 
получают 100\% пациентов. Частота проведения чрескожного коронарного вмешательства (стентирования) составила $20 \%$, аортокоронарного шунтирования $-11 \%$.

Основной коморбидный фон представлен такими заболеваниями как гипертоническая болезнь - 97\%, хроническая болезнь почек - 94\%, нарушение липидного обмена - 60\%, экзогенно-конституциональное ожирение - 49\%, сахарный диабет - 34\% (причём 42\% пациентов, страдающих сахарным диабетом, получают инсулинотерапию). Хроническая анемия встречается у 48,5\% больных. Острое нарушение мозгового кровообращения в анамнезе имели $34 \%$ исследуемых. Бронхолёгочная патология выявлена в $20 \%$ случаев. Ревматологические проблемы имеют 9\% больных. 14\% пациентов наблюдаются по поводу злокачественных новообразований.

Проанализированы значения кардиоспецифических ферментов в первые сутки от начала острой симптоматики. Средний уровень МВ-КФК составил 25,4 МЕ/л, тропонинов - 7,2 нг/мл.

На основании данных Эхо-КГ рассчитан средний показатель фракции выброса левого желудочка, равный 56,1\%.

Проведён анализ осложнений острого коронарного синдрома без подъёма сегмента ST. По результатам холтеровского мониторирования ЭКГ у 54\% пациентов наблюдаются нарушения ритма сердца, 53\% из которых приходится на фибрилляцию предсердий. В $6 \%$ случаев диагностирована острая левожелудочковая недостаточность. У 1 человека (3\%) верифицирована тромбоэмболия мелких ветвей лёгочной артерии.

При анализе групп крови выявлено, что 51\% исследуемых имеют первую группу крови. Возможно, данная группа крови является предиктором в развитии коронарной болезни сердца.

Выводы: Установлено, что среди пациентов кардиологического отделения ГБУЗ ПК «ГКБ №2 им. Ф.Х. Граля» ведущая роль принадлежит фармакотерапии. Наиболее распространённой патологией в рамках коморбидности является гипертоническая болезнь и хроническая болезнь почек. Основным осложнением является нарушение ритма сердца (преимущественно фибрилляция предсердий). Более половины исследуемых пациентов имеют первую группу крови.

\section{References}

[1] Cardiology journal. Association of multi-morbidity with the risk of cardiovascular complications in patients with acute coronary syndrome. 2018.

[2] Recommendations of the ESC for the management of patients with acute coronary syndrome without persistent ST segment elevation. 2015.

[3] Cardiovascular diseases. Newsletter-may VOZ. May 17, 2017. [Electronic resource] - URL http://www.who.int/ru/news-room/fact-sheets/detail/cardiovascular-diseases-(cvds). 


\title{
ASSESSMENT OF RISK FACTORS FOR CHRONIC PANCREATITIS
}

\author{
Dukov Denis ${ }^{1}$ \\ Kurilyak Maria $^{2}$
}

\begin{abstract}
Based on the analysis of medical histories, the risk factors for chronic pancreatitis were assessed and the incidence of pancreatits among other diseases of the gastrointestinal tract was determined. An increase in the incidence of chronic pancreatitis in dynamics was revealed.
\end{abstract}

Key words: chronic pancreatitis, risk factors for pancreatitis, analysis.

doi: http://doi.org/10.15350/F_7/33

Введение: За последние 30 лет отмечена общемировая тенденция к увеличению заболеваемости ХП более чем в 2 раза в разных возрастных группах. Заболевание имеет прогрессирующий характер, сопровождается развитием осложнений и снижением функциональной активности поджелудочной железы. Среди факторов, влияющих на возникновение и прогрессирование ХП, условно можно отнести злоупотребление алкоголем, курение табака, погрешности в диете, прием некоторых лекарственных препаратов, воздействия токсинов, действие стрессовых факторов и др. [1]

Цель исследования: Изучить особенности течения панкреатита на современном этапе 2017-2020гг. в сравнении с предыдущими годами 2005-2017гг.и исследовать влияние на здоровье различных факторов, таких как характер питания, наличие вредных привычек, физическая активность, нарушение режима труда и отдыха и др.

Материалы и методы: В 2020г. на базе ГБУЗ ПК «ГКБ №2 им. Ф.Х.Граля» проведен анализ 40 историй болезни пациентов, госпитализированных в гастроэнтерологическое отделение, отобранных случайно за период с 2017-2019гг. Производилось оценка течения заболевания, наличия сопутствующей патологии, факторов риска обострений заболевания и особенностей болевого синдрома.

Результаты исследования: Проведена статистическая обработка полученных данных. В процессе работы с архивными материалами историй болезни, удалось оценить частоту заболеваемости хроническими панкреатитом в динамике за минувшие 3 года (2017-20199гг). Анализ историй болезни пациентов гастроэнтерологического отделения ГКБ №2 выявил высокую встречаемость заболеваемости хроническим панкреатитом среди других болезней пищеварительного тракта $78 \%$ (2015г. - 57,9\%, 2016-56,8\%, 2017-62,7\%, 2018-70,6\%, 2019-75\%), как и в предыдущие годы- 2005г.-61,3\%, 2006г. -48,2\%, 2007г.-55,2\%, 2009г. - 55,6\%. Отмечен значительный прирост заболеваемости хроническим панкреатитом к 2020г. в сравнении с предыдущими годами.

Среди госпитализированных больных преобладали мужчины (61,3\%) в возрасте $60-70$ - 30,2\%, 70-80 лет-16,4\%. Женщин (38,7\%) в возрасте 60-70 - 28\%, 7080 лет-10\%. Выявлена низкая частота заболеваемости хроническим панкреатитом у лиц молодого возраста: женщины до 30 лет-4,2\%, мужчины до 30 лет-8,1\%, и у

\footnotetext{
${ }^{1}$ Dukov Denis, Perm State Medical University, Russia.

${ }^{2}$ Kurilyak Maria, Perm State Medical University, Russia.
} 
больных старше 80 лет (2-9,5\%). Среди сопутствующих заболеваний ЖКТ чаще всего встречалась патология билиарного тракта: хронический холецистит: $34,7 \%$, язвенная болезнь желудка и ДПК -26,6\%, ПХЭС- 22\%, дуоденит- 8\%, гастрит- 5\%, дуоденостаз-3,7\%. В большинстве случаев приступам панкреатита предшествовал алиментарный фактор. Было выявлены такие факторы риска как: употребление алкоголя- $35,6 \%$, курение- $21,2 \%$, нарушение диеты отмечено у $37,4 \%$, отягощенная наследственность- 10,2\%, травмы- 1,1\%. Анализ выявил вариабельность возникновения заболевания: 0т 1-10 дней-6,1\%, 2 месяца назад-8,1\%, полгода-год назад$18,3 \%, 1,5$ и более- $67,5 \%$. Сахарным диабетом страдает $14,2 \%$. Анализ клинических симптомов выявил преобладание болевого синдрома средней и высокой интенсивности у 76\% пациентов, и у $24 \%$ - малой интенсивности. В $67 \%$ случаев хронического панкреатита наблюдалась постоянная ноющая боль в правом и левом подреберье по типу «пояса» [2]. В сравнении в период 2005-2017гг. пациенты отмечали выраженный болевой синдром у 15\%, а малоинтенсивный-22,1\%.

Выводы: Множество различных факторов риска и прогрессирования ХП, несоответствие мнений о значимости тех или иных факторов, частое наличие сопутствующих состояний говорит о том, что данная тема широко открыта для обсуждения [3]. У пациентов, обследованных в гастроэнтерологическое отделениеГБУЗ ПК «ГКБ №2 им. Ф.Х.Граля» выявлена высокая частота встречаемости заболеванием хронический панкреатит, которое протекает с более выраженным болевым синдромом и каморбидной патологией.

\section{References}

[1] Russian journal of gastroenterology, hepatology, coloproctology. №2, 2017 p. 54-80.

[2] Russian journal «Medical alphabet. Gastroenterology». №9, 2017. p.50-55.

[3] Gastroenterology national guide: short edition, edited by V.T. Ivashkin, T. L. Lapina. M.:GeotarMedia, 2018. p. 209-242. 


\title{
FEATURES OF DIAGNOSIS OF CHRONIC HEART FAILURE
}

\author{
Kurilyak Maria ${ }^{1}$ \\ Udina Elena ${ }^{2}$
}

\begin{abstract}
This article discusses the concept of chronic heart failure and highlights the main symptoms of this pathology. Typical and atypical signs of objective examination of the patient, specific data of physical examination, as well as result of laboratory and instrumental studies indicating the presence of chronic heart failure are presented.
\end{abstract}

Key words: chronic heart failure, diagnostics, symptoms.

doi: http://doi.org/10.15350/F_7/34

Хроническая сердечная недостаточность (ХCH) представляет из себя синдром, при котором сердце не способно обеспечить оптимальную перфузию тканей из-за систолической и /или диастолической дисфункции желудочков. Таким образом, ХСН является не заболеванием, а осложнением уже имеющейся сердечной патологии.

Основными симптомами при ХСН будут являться одышка с приступами удушья и повышенная утомляемость, отеки ног и ощущение сердцебиения. Но, нужно учитывать имеющийся анамнез пациента, так как данные симптомы могут быть признаками и некардиологической патологии [1]. Если говорить об объективном осмотре пациента, то при нем будут наблюдаться типичные и нетипичные признаки ХСН. К типичным относят одышку, в том числе случаи одышки в ночное время, положение пациента ортопноэ и отеки в области лодыжек [2]. Менее типичными признаками будут являться наличие не только одышки, но и кашля, в том числе и в ночное время суток, наличие влажных хрипов в легких при аускультации, потеря или прибавление веса, диспепсические явления. При проведении обследования пациента выявляется повышение центрального венозного давления (ЦВД) в яремных венах (норма ЦВД от 3 до 10-15 мм.рт.ст.), гепатоюгулярный рефлюкс (набухание яремных вен при надавливании на область печени), который возникает в результате повышения давления в системе нижней полой вены, при аускультации наличие третьего тона - так называемый «ритм галопа», сердечные шумы а также определяется смещение верхушечного толчка влево [3]. Данные физикальные признаки являются наиболее специфичными для подтверждения ХСН. Менее специфичными являются: наличие периферических отеков, тахикардия, тахипноэ, гепатомегалия и асцит.

Если говорить о лабораторной диагностике ХCH, нужно сказать о биологических маркерах данной патологии - это натрийуретические гормоны: N-концевой пропептид натрийуретического гормона B-типа (NT-proBNP) и мозговой натрийуретический пептид (BNP) [2]. Для установления ХCH необходимо превышение концентрации первого в плазме крови выше 300 пг/мг и второго соответственно выше 35 пг/мл. Конечно, кроме биомаркеров стоит выполнять и обыденные лабораторные исследования: общий анализ крови - для того, чтобы исклю-

\footnotetext{
${ }^{1}$ Kurilyak Maria, Perm State Medical University, Russia.

${ }^{2}$ Udina Elena, Perm State Medical University, Russia.
} 
чить наличие анемии, определить уровень лейкоцитов и тромбоцитов, биохимический анализ крови - для того чтобы определить концентрацию калия, натрия, глюкозы, печеночных ферментов, креатинина а также определить скорость клубочковой фильтрации и оценить липидный спектр, общий анализ мочи. Кроме лабораторной диагностики проводятся также методы инструментальной диагностики ХCH - это электрокардиография (ЭКГ) и эхокардиография (ЭхоКГ). При оценке кардиограммы нужно определить характеристики сердечного ритма, частоту сердечных сокращений (ЧСC), оценить продолжительность QRS, выявить нарушения проводимости сердца - блокады левой и ли правой ножек пучка Гиса, гипертрофию миокарда. Стоит отметить, что нормальная электрокардиограмма практически исключает наличие у пациента ХСН. ЭхоКГ проводится пациентам с целью определения систолической или диастолической функции левого желудочка. Оценка систолической функции левого желудочка заключается в определении его фракции выброса [3]. Также к инструментальным методам диагностики относят рентгенографию грудной клетки. При ее результатам оценивают кардиоторакальный индекс (КТИ), при ХСН он будет превышать 50\%, также обращают внимание на признаки нарушения легочного кровотока (легочная гипертензия) и легочных заболеваний. Также существуют дополнительные методы инструментальной диагностики: коронарография, радионуклидная диагностика, катетеризация сердца, нагрузочные тесты, чрезпищеводная ЭхоКГ, стресс-ЭхоКГ, мультиспиральная компьютерная томография (КТ) и магнитно-резонансная томография (МРТ). Коронарографию проводят дополнительно, если пациент имеет клинические признаки стенокардии. Радионуклидную диагностику проводят пациентам с ишемической болезнью сердца. Катетеризация сердца проводится в том случае, если решается вопрос о трансплантации сердца или его механической поддержке. Нагрузочные тесты проводят для оценки эффективности лечения. Чрезпищеводную ЭхоКГ проводят пациентам, у которых при обычной процедуре ЭхоКГ возникают проблемы с визуализацией сердца в виду наличия у пациентов ожирения или хронических заболеваний легких, а также пациентам с клапанной патологией и подозрением на эндокардит. Стресс-ЭхоКГ проводится пациентам, которые имеют диастолическую дисфункцию левого желудочка при его сохраненной систолической функции. Мультиспиральная КТ проводится как наиболее информативный метод для оценки состояния коронарных сосудов. МРТ является оптимальным неинвазивным методом оценки особенностей анатомии и функции сердца.

\section{References}

[1] Fronseca C. Diagnosis of heart failure in primary care. Heart Fail. Rev. 2006. 11. p 11-90.

[2] Mant J., Doust J., Roalfe A., Barton P. et al. Systematic review and individual patient data metaanalysis of diagnosis of heart failure, with modeling of implications of different diagnostic strategies in primary care. Hlth Technol. Assess. 2009. 13. P 1-205

[3] Recommendations for chronic heart failure. National Russian society for the study of heart failure and diseases of the myocardium. 2016 


\title{
ASSESSMENT OF ADHERENCE OF PATIENTS WITH ARTERIAL HYPERTENSION
}

\author{
Kurilyak Maria ${ }^{1}$ \\ Udina Elena ${ }^{2}$
}

\section{Abstract}

The assessment of adherence to treatment of patients suffering from arterial hypertension, depending on the maintenance of the target blood pressure level, was carried out. The fact of bad habits is analyzed and the activity of maintaining a healthy lifestyle is determined.

Key words: commitment, treatment, arterially hypertension.

doi: http://doi.org/10.15350/F_7/35

Цель: Оценить приверженность к лечению лиц, страдающих артериальной гипертензией по достижению целевого уровня артериального давления. Определить наличие вредных привычек и активность ведения здорового образа жизни.

Материалы и методы: обследованы 30 человек: 9 мужчин (30\%) и 21 жен-

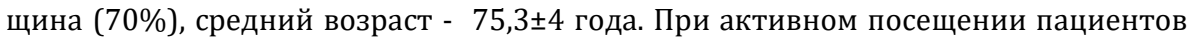
проводился опрос с заполнением соответствующей анкеты.

Полученные результаты: Из 30 пациентов полностью соблюдали рекомендованную антигипертензивную терапию 25 человек (83,3\%). Основными препаратами, используемыми пациентами в терапии артериальной гипертензии, являются: Лориста, Лозартан, Каптоприл, Анаприлин, Конкор, Беталок-Зок [3]. Пятеро пациентов из общей группы опрошенных не следовали рекомендациям. Среди регулярно принимающих лечение у 9 (36\%) артериальное давление сохранялось на целевом уровне, у 16 пациентов (64\%) наблюдалось периодическое повышение артериального давления выше рекомендованных значений, но поддавалось коррекции без обращения к врачу [2]. У 5 пациентов (16,6\%) артериальное давление превышало целевое значение и сопровождалось развитием гипертонического криза [3].

Вредные привычки: Из 30 человек 5 опрошенных пациентов $(16,6 \%)$ страдали злоупотреблением алкоголя. 15 человек употребляли алкогольные напитки только по праздникам и в незначительном количестве. У 10 из 30 опрошенных пациентов отсутствовал факт употребления алкоголя. Курение в анамнезе наблюдалось у 10 человек $(33,3 \%)$ - в настоящее время они бросили курить. 20 опрошенных пациентов $(66,6 \%)$ никогда не курили [1].

Здорового образа жизни придерживались 25 пациентов (83,3\%), из них 19 $(76 \%)$ занимались регулярными пешими прогулками на свежем воздухе в среднем по 1,5-2 часа в день, 6 человек (24\%) - активно выполняли упражнения по гимнастике в домашних условиях, 5 пациентов $(16,6 \%)$ не считали необходимым заниматься физическими нагрузками.

Заключение:

\footnotetext{
${ }^{1}$ Kurilyak Maria, Perm State Medical University, Russia.

${ }^{2}$ Udina Elena, Perm State Medical University, Russia.
} 
1. Приверженность к лечению отмечена у 83,3\% что подтверждается поддержанием целевых значений артериального давления.

2. Вредные привычки выявлены у 16,6\% пациентов, все они страдают злоупотреблением алкоголя.

3. Здорового образа жизни придерживаются 83\% опрошенных. Основные виды занятий данной группы - прогулки на свежем воздухе и занятия домашней гимнастикой.

\section{References}

[1] Evdokimova T.A., Kutuzova A.E., Bogdanova M. U., Rokhlin G.D. Methodological aspects of physical rehabilitation of patients with cardiovascular diseases. SPb., St. Petersburg, 2002. p. 28

[2] Karpov U.A., Deev A.D. Uncontrolled arterial hypertension - new opportunities in solving the proslem of improving the effectiveness of treatment. 2012. №2. p. 29-35

[3] Clinical recommendations for arterial hypertension in adults / Russian society of cardiology. 2020. p. $8-25$ 


\title{
STENTING AS ONE OF THE MODERN METHODS OF TREATMENT OF ACUTE CORO- NARY SYNDROME
}

\author{
Storozheva Christina ${ }^{1}$ \\ Udina Elena ${ }^{2}$
}

\begin{abstract}
Clinical observations were made of two patients with acute coronary syndrome followed by percutaneous coronary intervention. One of the patients had a coronary stenting on the background of myocardial infarction, and the other patient had an acute coronary syndrome.
\end{abstract}

Key words: percutaneous coronary intervention, acute coronary syndrome, myocardial infarction.

doi: http://doi.org/10.15350/F_7/36

Цель: Изучить метод лечения острого коронарного синдрома с помощью чрескожного коронарного вмешательства.

Материалы и методы: обследованы двое мужчин 61 года и 67 лет. При посещении и обследовании пациентов проводился опрос и клинические наблюдения.

Стентирование коронарных артерий или чрескожное коронарное вмешательство - операция, позволяющая восстановить кровоток в артериях сердца (коронарных артериях) путём имплантации стентов в месте сужения коронарной артерии.

Различают два главных вида стентов: металлический и с лекарственным покрытием

Металлический стент (Bare Metal Stent) - внутрисосудистый протез из нержавеющей стали или кобальт-хромового сплава. Использование металлических стентов связано с риском тромбоза в первые 30 дней и требует двойной антитромбоцитарной терапии в течении 1 месяца, а также 20-30\% риском рестеноза (повторного сужения сосуда) в течение 6-9 месяцев после имплантации.

Стент с лекарственным антипролиферативным покрытием - внутрисосудистый протез из кобальт-хромового сплава с покрытием, высвобождающее лекарственное вещество, препятствующее повторному сужению сосуда. Лекарственный слой в последствии растворяется.

Полученные результаты: У первого исследуемого пациента, мужчины 61 года с диагнозом: Гипертоническая болезнь ll стадии. Атеросклероз аорты. AB-блокада 1 степени, более 3 лет. При прохождении профосмотра на работе (ООО АВИАЦИОННАЯ КОМПАНИЯ «АВИВСТАР-ТУ») было выявлен атеросклероз брахицефальных артерий. Было проведено эндоваскулярное лечение в объёме операции чрескожного коронарного вмешательства со стентированием правой коронарной артерии. Ранний послеоперационный период без осложнений. Курс стационарного лечения завершён благополучно. Пациент трудоспособен.

У второго исследуемого пациента, мужчины 67 лет с диагнозом: ИБС. Нестабильная стенокардия l B. Прогрессирующая lll ФК. Артериальная гипертензия lll

\footnotetext{
${ }^{1}$ Storozheva Christina, Perm State Medical University, Russia.

${ }^{2}$ Udina Elena, Perm State Medical University, Russia.
} 
стадии, 2 степени, риск 3. Перенесенное стентирование ПМЖА ср/3 Resolute integrity 2.25*30мм, ВТК Хience 2,25*18мм от 23.03.2015г. При физической нагрузке начал чувствовать давящую боль за грудиной, был направлен в больницу участковым терапевтом. Было проведено консервативное лечение и выполнено первичное чрескожное коронарное вмешательство и ТЛБАП - прямое стентирование ПКА в среднем сегменте (DES, Xience Xpedition 3,5 х 28 мм). Послеоперационный период без осложнений. На фоне проведенного лечения состояние улучшилось.

Заключение: Из проведенных клинических наблюдений можно сделать следующий вывод, что методом чрескожного коронарного вмешательства купируется острый коронарный синдром и нормализуется гемодинамика.

\section{References}

[1] Clinical cardiology: diagnosis and treatment. Edited by L.A. Bokeria, E.Z. Golukhova. M.: NCSSH A.N. Bakuleva RAMN, 2011, p. 864.

[2] Shakhnovich R.M. Acute coronary syndrome with ST segment elevation: a guide. M.: GEOTARMedia, 2010. p. 376

[3] Shilov A.M., Melnik M.V., Osiya A.O., Selezneva M.G. Classification, clinical features and diagnosis of inforoute Mercado // Journal of anesthesiology and resuscitation. 2010. №3. p. 50-58. 


\title{
NATURAL SCIENCES AND TECHNICAL SCIENCES
}

\section{AGROMELIORATIVE MEASURES TO IMPROVE AND MAINTAIN SOIL FERTILITY}

\author{
Sattorova Maxfuza ${ }^{1}$ \\ Boltaev Muxlis ${ }^{2}$
}

\section{Abstract}

The Earth is considered the only house-the common duty of more than 200 countries, about 7 billion people. Protection of nature and rational use of natural resources can have its effect on the basis of an international agreement based on a global scale.

Key words: Soil fertility, agroecotism, erosion, biogeocenosis, antropogen landscape, degradation.

doi: http://doi.org/10.15350/F_7/37

Повышение урожайности сельскохозяйственных культур в настоящее время является одним из наиболее актуальных вопросов в нашей стране. Не секрет, что повышение урожайности сельскохозяйственных культур решается в первую очередь за счет повышения их продуктивности на основе углубленного изучения свойств и способов обработки почв. В практике сельскохозяйственного производства во многих случаях свойствами почв пренебрегают, особенно их механическим составом, агрегатным состоянием, плотностью, урожайность сельскохозяйственных культур осуществляется в основном за счет внесения минеральных и органических удобрений, а повышение плодородия почвы не придает значения проблеме ее хранения. Управление плодородием почв и его повышение является одним из наиболее актуальных вопросов. Потому что продуктивность будет зависеть не только от удовлетворения потребности почвы в пищевых элементах путем обеспечения их минеральными или органическими удобрениями, или изготовления качественных плугов для вспахивания почвы, но и от поддержания жизненно важных норм, таких как питательные вещества, вода-воздух, тепло и свет, которые считаются космическим фактором для почвы, и обеспечения пропорциональности между ними.

На территории нашей республики различные климатические условия и многие типы почв, и в таких условиях решение вышеперечисленных проблем усложняется. Сельскохозяйственные угодья являются основной составляющей экологической системы нашей земли, а другие части природы тесно взаимосвязаны с водным, лесным, животным и растительным миром, минеральными и другими подземными ресурсами. Без земли и почвы другие природные ресурсы не могут быть использованы. Поэтому в результате обработки почв землевладельцами, сейчас и в ближайшем будущем, вся окружающая среда может быть повреждена.

Это приводит к нарушению верхнего слоя почв, их эрозии, засолению, забо-

\footnotetext{
${ }^{1}$ Sattorova Maxfuza, teacher of the Department of Soil Science of Bukhara State University. ${ }^{2}$ Boltaev Muxlis, student of the Faculty of agronomy and biotechnology of Bukhara State University.
} 
лачиванию, химическому и радиоактивному загрязнению, а также ухудшению экологической обстановки в природе. Именно по этой причине охрана земель рассматривается как создание условий для устойчивого развития общества и обеспечения жизнедеятельности человека. Соответственно, все земли, независимо от их целевого сельскохозяйственного назначения должны быть защищены.

Хотя существует риск засоления и накопления солей на орошаемых землях сельского хозяйства, сельскохозяйственные угодья продолжают терять свое плодородие под воздействием вредных химических веществ, которые накапливаются в почве, ноль указывает на то, что мер по борьбе с засолением недостаточно. Чрезмерно засоленные почвы всегда дают меньший урожай, чем засоленные почвы. Такие земли требуют больше труда и финансирования со стороны государства и землепользователей. Поэтому сохранение и постоянное повышение продуктивности земель, рациональное и эффективное их использование следует рассматривать как неотъемлемую часть государственной земельной политики, важнейшую отрасль программ экономического развития страны.

Почвы делятся на пять групп по степени засоления: 1) несоленые; 2) слабосоленые; 3) умеренно засоленные; 4) сильно засоленные; 5) солянистые. При группировке почв по степени засоления обращают внимание на общее количество солей и хлора, которые легко растворяются в воде, в которой они содержатся. При повышенной засоленности ухудшается качество почвы, снижается продуктивность, возникает необходимость в проведении мелиоративных мероприятий. Перед посадкой культуры в сельскохозяйственном использовании засоленных почв необходимо провести следующие мелиоративные мероприятия на таких землях в полном объеме: - работы по тщательной разработке планов водопользования на основе правил, полностью отвечающих требованиям агрономии: переход на новую оросительную систему, строительство гидротехнических сооружений из оросительных пунктов, водосбережение;

- можно удалить и улучшить засоление почв различной степени засоления, остановив непрерывный подъем соленой воды снизу вверх по капиллярным путям и устранив вредные соли, накопившиеся в почве;

- для улучшения физико-химических свойств почв необходимо вносить в почву гипс. Его особенность заключается в том, что он сжимает натрий и кальций в абсорбирующей коре почвы, а также улучшает физическое состояние почвы;

- такие мероприятия, как удобрение засоленных почв, глубокая вспашка засоленного слоя, введение широкого спектра ирригационных работ, выемка котлованов, снижение их уровня считаются одними из основных мероприятий по повышению плодородия, улучшению физико-химических свойств почвы. Если агромелиоративные мероприятия применяются своевременно и правильно, то можно высадить урожай на этих почвах и постоянно получать высокий урожай;

- промывка засоленных почв считается основной мелиоративной мерой, обеспечивающей хорошую работу горизонтальных и вертикальных дренажных канав. При промывке почвы водой засоленность почвы может возрасти, если при промывке водой не обращают внимания на засоленность почвы, глубину и соленость грунтовых вод.

Правильное чередование посадок улучшает мелиоративное состояние засоленных и заболоченных земель, повышает плодородие почвы, повышает урожайность. Мелиоративный эффект чередования посадок-почва становится плодородной, в которой увеличивается содержание органических и питательных веществ, улучшаются ее физические свойства, а влага испаряется меньше.

Если учесть, что пашня по отношению к населению нашей планеты сегодня меньше, чем 10-20 лет назад, то очевидно, что необходимо повысить плодородие 
почвы, удвоить урожайность сельскохозяйственных культур, утроить урожайность, то в ближайшем будущем это останется главной задачей земледелия.

К сожалению, сегодня почвенный слой поглощается, хорошая плодородная земля уменьшается. Без рационального использования земельных ресурсов во всех отношениях, без принятия мер по защите почвенного слоя от различных деградационно-эрозионных и других неблагоприятных воздействий, без проведения мероприятий по сохранению и исследованию целевых земель, которые относятся к сельскому хозяйству, нет возможности решения перечисленных выше проблем. Повышение плодородия почвы во многом зависит от комплекса мероприятий, направленных на поддержание бережного и щадящего отношения к ней, ее улучшение. Учитывая это, крайне важно последовательно ускорять сельскохозяйственное производство, рационально использовать земельный фонд, разрабатывать пути решения проблем, связанных с повышением продуктивности каждого гектара орошаемых земель, их экономической эффективности.

\section{References}

[1] Mahsudov M. H., Adilov A. A. Rosesonly.Toshkent.1998. 


\title{
DEVELOPMENT OF THE MELON FLY (MYIOPARDALIS PARDALINA BIG) IN THE CONDITIONS OF KARAKALPAKSTAN
}

\author{
E. Toreniyazov ${ }^{1}$ \\ R. Yusupov
}

\section{Abstract}

The article describes the development of biological and ecological features and harmfulness of melon fly on crops of melons in conditions of Karakalpakstan. It is studied the efficiency of the deep autumn plowing of soil against overwintering pests, special traps to kill the larvae and pupae, chemical treatments against the imaginal phase melon fly on crops of melon. The impact on the conservation of wild melon pest overwintered individuals. Recommended optimal protective measures in extreme conditions of Karakalpakstan.

Key words: melon fly, melon, pest, biological, chemical treatment efficacy.

doi: http://doi.org/10.15350/F_7/38

The study of distribution area and bioecological peculiarity of melon fly confirms that this species has high ecological plasticity, can adapt to the extreme conditions of climate. The climate of territory of the Republic of Karakalpakstan is sharply continental, cold (air temperature is reduced till minus $10-20^{\circ} \mathrm{C}$ ) period is continued from October to March (150-160 days), rising of air temperature reaches till $+40+45^{\circ} \mathrm{C}$ in summer, relative humidity is reduced for $15-20 \%$, i.e. a zone is extreme. The rise of air temperature from $10{ }^{\circ} \mathrm{C}$ is observed in the first half of April, during the vegetation period accumulates 2000 $2100{ }^{\circ} \mathrm{C}$ of effective temperature. In spite of this the melon fly with the beginning of appearance in the region widely spread, inflict a huge damage to fruits of cucurbitaceous.

From the years of appearing the pest in the territory, information gathered using information about their morphological indications, phases of development. As a result of this, it is defined that the kind which is spread in our territory is the melon fly of Central Asia or Beludjistan (Carpomya (Myiopardalis) pardalina Big). It is known that the pest decreased from vegetables $90-95 \%$ melon, $30-45 \%$ watermelon, $20-25 \%$ cucumber in the first years.

When studying melon fly from the period of appearing, according to the ontogenesis it is a kind of fully developing insects, there are four phases of development: egg, worm, pupa and imago.

The pest is mainly in the phase of pupa in the depth $5-20 \mathrm{~cm}$ in soil in winter, in spring when melons blossom first flies start to fly. As a result of the investigation which was held according to this, the first growth phases start to fly on June 2, 2010; June 2, 2011; May 30, 2012; May 31, 2013; June 5, 2014; June 7, 2015; June 3, 2016; June 10, 2017; June 2, 2018; June 3, 2019. After eating additional food, flies pair and start to lay eggs. Female fly lays average 60-110 eggs during her life. Worms appear during 3-7 days from the eggs which laid down the crust of vegetables. Worms eat food during 11-18 days inside the vegetable, carry out doll phase in the depth 3-20 cm of soil. Growth flies start

\footnotetext{
${ }^{1}$ E. Toreniyazov, doctor of agricultural science, professor, Uzbekistan.

${ }^{2} R$. Yusupov, doctor of philosophy in agricultural science, Tashkent State Agrarian University Nukus branch, Uzbekistan.
} 
to fly from dolls in 12-18 days and gives generation 3-4 times during the period of vegetation.

Worms of the pest are white, without legs, length is about 9,0-10,0 mm, at the last segment of the body there are 2 small growers. As a reason of not developing legs, worms move by biting with mouth.

Living condition of the growth of melon fly was studied related to the level of additional eating. Researches were carried out in laboratory conditions where the temperature of air is $25,0-32,0^{\circ} \mathrm{C}$, comparative moisture is average $40-60 \%$.

As a result of researches it is known that the growth of the pest lived about 2-10 days in the environment without food, about 6-28 days in the environment where the food is given. Above mentioned information is conformed in observations which carried out in July, August. It is defined from this, that additional food is comfortable condition for the life of the pest and if the fly which come out from the doll eats additional succulent it lives more days and lays eggs actively.

It is known that nowadays using chemical method against the growth of melon fly gives high result. Scientific-researches are carried out in the aim of increasing profitability rate of this method.

It is defined in the research works that chemical preparations are useful against the growth of melon fly. Information about received results are given in the $1^{\text {st }}$ table, it is defined in the table that when melon fly gathered in 100 plants $6,6-8,0$, using chemical preparations decreases the number of the growth of pest to minimal level, the next day the number is decreased. After using the method on $14^{\text {th }}$ day it was obvious that $85,9-$ $96,4 \%$ result is achieved in the field.

The number of pests in the fields where chemical fighting method was used was in the minimal level than the fields where chemical fighting method was not used, it helped to save the harvest.

In conclusion, the growths of melon fly, related to temperature of the environment and other abiotic factors appear after winter at the end of May, at the beginning of June in the condition of Karakalpakstan. Mother pests, which ate additional food, lay more eggs to upper part of vegetables.

If the growth of the pest does not eat additional food, it lives 2-10 days, if eats additional food lives 6-28 days and lays about 110 pieces of eggs. 89,1-96,4\% usefulness is achieved by using permitted chemical preparation; when using the method of $98-100 \%$ destroying by using catchers of worms, dolls, main part of the first generation was destroyed and the harvest is saved.

\section{References}

[1] Toreniyazov.E.Sh., Abbatov. O. Causes of melon flies emergence and measures to control them // Agricultural Journal of Uzbekistan. Tashkent, 2003. -№5. -25 p.

[2] Yusupov.R.O. Biology and economic significance of melon fly and development of its control measures. Abstract of dissertation for the docror of phylosophy $(\mathrm{PhD})$ degree on agricultural sciences. 06.01.09. - Tashkent, 2018. - 20-25 pp. 


\title{
REARING TWO-YEAR-OLD OF DIFFERENT BREEDS OF CARP IN CAGES CONDITIONS OF THE REPUBLIC OF UZBEKISTAN
}

\author{
B.B. Norboyev ${ }^{1}$ \\ A.O. Akramov ${ }^{2}$ \\ N. Adizova ${ }^{3}$ \\ D. Kholmirzayev ${ }^{4}$
}

\section{Abstract}

In the article, in the conditions of the Republic of Uzbekistan, imported two-summer old carp of different breeds are raised in cages under the same conditions of storage and feeding for 196 days. The indicators of fish-water, productivity and quality of commercial fish of imported Hungarian carp on the basis of imports were studied in comparison with local carp breeds.

Key words: Carp, two-year-old, breed, hybrid, cage, fish survival rate, food conversion, dressing yield, fish breeding indices.

doi: http://doi.org/10.15350/F_7/39

Introduction. In Uzbekistan, which is one of only two countries in the world to cross the border to access the sea, limited water resources are a major obstacle to fisheries development. Nevertheless, there are many natural lakes and water reservoirs in the territory of the Republic, and with the effective use of modern intensive methods of aquaculture, good results can be obtained in the cultivation of commercial fish and fish products.

For commercial fish farming, it is economically important to use the species and breeds of fish with increased productive characteristics, vitality and resistance to rearing conditions.

Carp, which is an object of aquaculture, plays an important role in the fisheries of many countries around the world. Flocks of carp in fisheries in Uzbekistan, the cultured local form consists of hybrid offspring of Ukrainian, Hungarian, Russian and other carp breeds. The fish productivity of hybrid generations is much lower than that of pure breeds and does not have good economic efficiency. Mixed breeds carp are present in almost all fish farms and their branded fish quality is much lower. Therefore, in order to accelerate the development of the fishing industry, high-yielding, pedigree parent fish and larvae are imported, nurtured in our own climate, and quality fish products are obtained from them. Cage fish farming and possibility of growing carp in cages are a great reserve for increasing the production of salable fish and fish products.

Material and methods. The experiments were carried out in $2019 \mathrm{y}$, at a fishery named "Golden Fish Lake" in the Tudakul reservoir, Navoiy region. The material for the cultivation of commercial fish in cages was used by imported breeds Hungarian carps: Bikal mirror, Tata scale, Vietnamese, local mirror and local scaled breeds. Fish were fed on the basis of natural and full-value feed recipes, and their growth rates were monitored.

${ }^{1}$ B.B. Norboyev, Samarkand institute of veterinary medicine, Samarkand, Uzbekistan.

${ }^{2}$ A.O. Akramov, Samarkand institute of veterinary medicine, Samarkand, Uzbekistan.

${ }^{3} N$. Adizova, Samarkand institute of veterinary medicine, Samarkand, Uzbekistan.

${ }^{4}$ D. Kholmirzayev, Samarkand institute of veterinary medicine, Samarkand, Uzbekistan. 
Specific fish characteristics of each breeds were recorded. For statistical processing of the material used the generally accepted methodology and the program "STATISTIKA".

Results and discussion. For research, 7500 individuals were selected for each two-year-old, different carp breeds, age (1+), with an average weight of 80-100 grams and placed in 5 cages of 1500 pieces each. Feeding was carried out with granular feed 4 times a day at regular intervals according to the research scheme. During the rearing period, commercial two-year-old carp in cages, all experimental fish were in the same condition. Fish were reared in a stationary cage system of 3,5×2,5×2,0 $\mathrm{m}$ in size, the useful volume of water in cages was $17,5 \mathrm{~m}^{3}$, for 196 days. The dynamics of changes in live weight and fish breeding indicators of fish are presented in (table 1).

Table 1

Fish breeding and commercial indices of two-year-old of different breeds of carp, rearing in cages

\begin{tabular}{|c|c|c|c|c|c|}
\hline \multirow{2}{*}{$\begin{array}{c}\text { Fish breeding } \\
\text { indices }\end{array}$} & $\begin{array}{c}\text { Bikal } \\
\text { mirror }\end{array}$ & Tata scaly & $\begin{array}{c}\text { vietnam- } \\
\text { ese mir- } \\
\text { ror }\end{array}$ & $\begin{array}{c}\text { Local mir- } \\
\text { ror }\end{array}$ & $\begin{array}{c}\text { Local } \\
\text { scaly }\end{array}$ \\
\cline { 2 - 6 } & $1+$ & $1+$ & $1+$ & $1+$ & $1+$ \\
\hline Fish age, years & 87 & 90 & 89 & 95 & 96 \\
\hline $\begin{array}{c}\text { Fish survival rate, \% } \\
\text { Harvest density, number } \\
\text { piece /m }\end{array}$ & 86 & 86 & 86 & 86 & 86 \\
\hline $\begin{array}{c}\text { Number of two-year-old fish } \\
\text { in the cages }\end{array}$ & 1500 & 1500 & 1500 & 1500 & 1500 \\
\hline $\begin{array}{c}\text { Body weight, of fingerlings, g } \\
\text { At the beginning of the exper- } \\
\text { iment }\end{array}$ & $80-100$ & $80-100$ & $80-100$ & $80-100$ & $80-100$ \\
\hline $\begin{array}{c}\text { Body weight, of commercial } \\
\text { fish, g }\end{array}$ & 1655 & 1786 & 1570 & 1354 & 1300 \\
At the end of the experiment & 2160 & 2411 & 2167 & 1929 & 1872 \\
\hline Yield of commercial fish, kg & 123,4 & 137,7 & 119,7 & 110,3 & 106,9 \\
\hline Fish productivity, kg/m ${ }^{3}$ & 2,57 & 3,16 & 2,95 & 4,19 & 4,58 \\
\hline Food conversion & 62,3 & 58,9 & 57,2 & 54,7 & 50,1 \\
\hline Dressing yield, \% & & & & \\
\hline
\end{tabular}

The results of the experiment show that the fish productivity and quality of commercial fish of imported Hungarian breeds on the basis of imports were much higher than that of local breeds. In particular, at the end of the experiment, the average live weight of the finished fish was the highest, $1786 \mathrm{~g}$ in the Tata breed, which is $432 \mathrm{~g}$ and $486 \mathrm{~g}$ or $31,9 \%$ and $35,8 \%$ more than in the local mirror and scaly breeds. When reared in cage, the highest fish yield were for Tata $137,7 \mathrm{~kg} / \mathrm{m}^{3}$ and Bikal $123,4 \mathrm{~kg} / \mathrm{m}^{3}$ breeds. The food conversion of Bikal breed, which used the given mixture-feed with high efficiency, was 2,57 . One of the main indicators of commercial fish quality, the relative dressing yield in Bikal was $62,3 \%$, which is 7,6 \% and $12,2 \%$ higher than the local mirror and scaly breeds.

Conclusion. The results of the research indicate that the use of two-year-old foreign breeds of carp for rearing in cages in the condition of the Republic of Uzbekistan. For the first time, the predominant indicator of the Hungarian carp breeds for the production of commercial fish was established. They have their own high fish productivity, the best payment for feed, good food quality (low fat content) and commercial of fish. References

[1] Bogeruk A.K. Catalogue of Carp Breeds (Cyprinus carpio L.) of the Countries of Central and Eastren Europe .-M. 2008. 160 p. 
[2] Kryukov V.I., Muzalevskaya Yu.A., Yushkov P.A., Fisheries. Breeding of carp. Tutorial. - Orel, 2007., p 50.

[3] Kholmirzaev D., Norboyev B.B., Akramov A. Features of intensive fish farming // "Fisheries of the Uzbekistan”. j., №2, pp. 24-26.

[4] Norboyev B.B. Morphological characteristic of Hungarian carp breeds and acclimatization in farm ecological conditions // "Animal husbandry and breeding” j., 2019 №4 -pp. 33-34. 


\title{
FIBERGLASS PIPES FROM THE UNSATURATED POLYETHER ON THE BASIS OF ALCOHOLYSIS PRODUCTS OF SECONDARY POLYETHYLENE TEREPHTHALATE
}

\author{
A.B. Juraev ${ }^{1}$ \\ M.G. Alimuhamedov ${ }^{2}$ \\ F.A. Magrupov ${ }^{3}$
}

\section{Abstract}

In the paper, results of synthesis of unsaturated polyether from alcoholysis products of pipe purposed are exposed. Appropriating to technological norms of an import unsaturated polyether of the grade «Body» resin of grade PU-MA-03 is developed for the manufacture of fiberglass pipes.

Key words: an alcoholysis product, maleic anhydride, a condensation polymerization, physical and chemical properties, technological properties.

doi: http://doi.org/10.15350/F_7/40

Introduction.For last decade in the world the manufacture of polyethylene terephthalate increased from 37,5 million tons to 70,0 million tons. 21,5 million tons of them are used in the manufacture of polymer container - bottles. In the Republic hundred thousand tons of various polymers are annually delivered and in particular 40-45 thousand tons of polyethylene terephthalate. Accumulation of these bottles - waste has outgrown as one of the most actual problems of environment protection. They cannot be burnt, it is impossible to bury, because burning products of polyethylene terephthalate bottles pollute the atmosphere emitting considerable quantities of smoke black and highly toxic products.

On the other hand at the correct approach, the waste of any polymer and in particular polyethylene terephthalate is accessible and low-cost raw materials for the manufacture of new aspects of polymers, namely synthesis of unsaturated polyethers of fiberglass pipes.

Fiberglass pipes represent the composite structural materials combining high strength with rather small density. In different industries, they successfully compete to such traditional materials, as metals and their alloys, concrete, glass, ceramics, wood. In some cases the designs meeting to special technical requirements can be created only from fiberglass. Products from this material obtained especially a wide circulation in the apparatus intended for work in extreme conditions - in shipbuilding, aircraft and space technics, the equipment of petrochemical and gas branches [1].

In the light of stated the purpose of the given work was creation of a unsaturated polyether (UPE) from secondary polyethylene terephthalate (SPET) the packages which are meeting the requirements of the manufacture of fiberglass pipes.

Experimental part. Synthesis of USPET has been carried out in four-necked flask supplied with the mechanical srirrer, the Dinah-Stark trap, the thermometer and a capillary for a gating through of inert gas. In the four-necked flask alcoholysis products SPET,

\footnotetext{
${ }^{1}$ A.B. Juraev, Tashkent chemical-technological institute, Uzbekistan.

${ }^{2}$ M.G. Alimuhamedov, Tashkent chemical-technological institute, Uzbekistan.

${ }^{3}$ F.A. Magrupov, Tashkent chemical-technological institute, Uzbekistan.
} 
glycols (diethyleneglycol, propylene glycol) and maleic anhydride. For the condensed water extraction xylene or toluene have been used. Stock temperature slowly lifted to $(220 \pm 5)^{\circ} \mathrm{C}$ for $2-3$ hours. Synthesis has been conducted at stock temperature of $220^{\circ} \mathrm{C}$ for 3-6 hours before the neutralization number reaches 20-30 mgKOH/g. Process has been controlled with the definition of neutralization number of UPE. In the capacity of an alcoholysis product of SPET for the synthesis of UPE products obtained at various ratios of SPETP have been used: diethyleneglycol $(D E G)=1: 2$ el. link/mole and durations of reaction is 6 hours. All operations have been carried out at a constant gating through a nitrogen flask.

Discussion. Processibility of UPE has been estimated on the following technological parameters, the pipes accepted in the manufacture: physical confugiration - visually, conditional viscosity - on the Brookfield device at $23^{\circ} \mathrm{C}$, the gelatinization time, the maximum exothermal temperature at hardening and duration of a self-heating has been defined in accordance with SS 22181-91.

Initial researches have been directed on studying physical and chemical and technological properties of UP applied in the manufacture of fiberglass pipes (China manufacture). Thus defined in vitro have had following properties: density $-1,11 \mathrm{~g} / \mathrm{sm}^{3}$, the maximum portion of styrene - 29,2 \%, viscosity on B3-6 - $23 \mathrm{~s}$, neutralization number $-19,2$ $\mathrm{mgKON} / \mathrm{g}$, the gelatinization time - $14 \mathrm{~s}$, the maximum maximum exothermal temperature $-137^{\circ} \mathrm{C}$, duration of self-heating - 23 minutes For hardening it has been used a peroxide mixture of methyl ethyl ketone and cobalt naphthenate in the ratio of 1:0,5 mass p:mass p.

In the previous work it has been shown possibility of synthesis of unsaturated polyethers acceptable for the manufacture of polymer-composite pipes on the production technology HOBOS [2]. Thus developed modified resin meets to technological norms of an import unsaturated polyether for the manufacture of polymer-composite pipes. The obtained unsaturated polyester resins have had high parametres on strength at a static bend and heat stability on Vick in comparison with industrial of UPE type "Body".

Table 1

Comparative table of physical-chemical and mechanical characteristics of experimental batch of synthesized UPE with anolog

\begin{tabular}{|c|c|c|c|c|}
\hline Indicators & $\begin{array}{c}\text { Requirements } \\
\text { of standard } \\
\text { grade «Body» }\end{array}$ & $\begin{array}{c}\text { Grades of UPE } \\
\text { grade } \\
\text { «PU-MA-03» }\end{array}$ & $\begin{array}{c}\text { UPE } \\
\text { grade «Body» }\end{array}$ \\
\hline Appearance & $\begin{array}{c}\text { Transparent } \\
\text { liquid } \\
\text { light yellow col- } \\
\text { our }\end{array}$ & $\begin{array}{c}\text { Untransparent } \\
\text { yellow colour }\end{array}$ & $\begin{array}{c}\text { Transparent } \\
\text { liquid } \\
\text { light yellow col- } \\
\text { our }\end{array}$ \\
\hline & 1120 & 1123 & 1121 \\
\hline & $\begin{array}{c}\text { Viscosity, on Brookfield, } 23^{\circ} \mathrm{C}, \\
\mathrm{mPa} \cdot \mathrm{s}\end{array}$ & $250-500$ & 465 & 420 \\
\hline & Gelatinization time, min. & $9-18$ & 12,5 & 14 \\
\hline & $\begin{array}{c}\text { Maximum temperature of } \\
\text { self-heating, }{ }^{\circ} \mathrm{C}\end{array}$ & $\geq 130$ & 137 & 136 \\
\hline & End hardening time, min. & $20-30$ & 22,5 & 23,5 \\
\hline & The content of dry residue, $\%$ & $63-68$ & 65,5 & 68 \\
\hline & Impact strength, $\mathrm{kDj} / \mathrm{m}^{2}$ & $\geq 4$ & 4,5 & 4,5 \\
\hline & Strength at static bend, $\mathrm{MPa}$ & 100 & 99,8 & 92,5 \\
\hline
\end{tabular}


In further analyzing foreign works on the synthesis of UPE $[3,4]$ it is revealed a compounding of synthesis UPE with application in the capacity of alcoholic agent of alcoholysis products of SPET. But it is necessary to note that the length of a segment at alcoholysis products strongly influences on technological namely, viscosity, maximum exothermal temperature. Thereupon by us it has been informed on the synthesis of unsaturated polyethers intended for fiberglass pipes [5]. Thus, it is shown workings out of compounding of UPE closes to import resins. Synthesised UPE had an insignificant deviation of magnitudes of exothermal temperature (in the smaller party) and durations of a selfheating.

On the basis of the carried out researches the temporary production schedules on manufacture of UPE of grade PU-MA-03 have been developed. In the experimental industrial conditions the output of an experimental batch of developed UPE (tab. 1) has been attained.

The given tables show that synthesized UPE brands PU-MA-03 quite meets to the requirements of input control for the resin «Body» used in the manufacture of fiberglass pipes.

Conclusion. Thus, the conducted complex researches showed organization possibility of the manufacture of unsaturated polyether in Uzbekistan. Unsaturated polyester resin of grade PU-MA-03 has required parameters on the following indicators: density, viscosity, gelatinization time, self-heating temperature and end hardening time.

It has been determined that compositions of hardened UPE grades PU-MA-03 at the static bend surpass in values of strength to an industrial polyether of the grade «Body».

Thus, the conducted researches showed basic possibility of application of UPE of grade PU-MA-03 on the basis of secondary of polyethylene terephthalate for the manufacture of fiberglass pipes.

\section{References:}

[1] Lebedev I.K., Naumets V.N. Korrozionno-stoykie trubi i yomkosti iz stekloplastikov: materiali, svoystva, texnologii. -M.: Enas, 2015. - $448 \mathrm{~s}$.

[2] Juraev A.B., Alimuxamedov M.G., Magrupov F.A., Nazirov B.I. Nenasishennie poliefiri iz petsoderjashix otxodov i razrabotka kompozitsiy dlya trub na ikh osnove // Vestnik TashGTU, 2016, - №2. - S. 168-173.

[3] Sunain Katoch. Kinetics study of Unsaturated Polyester synthesized from waste PET // Asian Journal of advanced basis sciences. 2013. №1. - P. 87-92.

[4] Qin, J.R. Jia, L. Zhao, Z.X. Huang, S.W. Zhao, G.W. Zhang, B.F. Dai. Synthesis and characterization of soybean oil based unsaturated polyester resin. // Adv. Materials research. 2012, v.393-395. - P. 349-353.

[5] Juraev A.B., T.A.Nizamov, R.I.Adilov, M.G.Alimuxammedov, F.A.Magrupov. Opitno-promishlennie ispitaniya kompozitsii nenasishennikh poliefirov na osnove vtorichnogo poliztilentereftalata $\mathrm{v}$ proizvodstve polimernix trub // Jurnal «Kompozitsionnie materiali'». 2011. - №2. - S. 66-69. 


\title{
STRUCTURE OF BRACTS OF SOME FAMILIES OF THE GENUS ACANTHOPHYLLUM
}

\author{
E. Ruzmatov ${ }^{1}$ \\ D. Tuyzieva ${ }^{2}$ \\ B. Nizomova ${ }^{3}$ \\ O. Yuldasheva ${ }^{4}$
}

\section{Abstract}

The article discusses the structure of the bract of some representatives of the genus Acanthophyllum. Some types of Oligosperma section, sec. Turbinaria, sec. Pleiosperma, sec. Maciostegia It was shown that representatives of the genus Acanthophyllum noticeably differ among themselves in terms of the anatomical and morphological structure of this part of the flower; therefore, none of the signs of its structure can characterize the genus Acanthophyllum as a whole. However, species and sections within the genus differ in one way or another.

Key words: Acanthophyllum, genus, section, species, subspecies, bract, simple and glandular hairs, epidermal cells, epidermis, stomatal apparatus, stomata.

doi: http://doi.org/10.15350/F_7/41

В систематике растений структура и распределение эпидермальных выростов имеют важное диагностическое значение [1]. Если густота опушения в значительной мере может варьировать в зависимости от фазы развития и экологических условий мест произрастения, то форма волосков обусловлена генетически и меньше подвержена влиянию окружающей среды и поэтому является достаточно надежным таксонометрическим признаком [2].

Прицветнички всех представителей рода Acanthophyllum сравнительно густо опушены простыми однолучевыми, состоящими из 1-3 клеток, трихомами длиной 97-112 мкм. Из 13 изученных видов сек. Oligosperma 11 опушены только простыми волосками и лишь два вида -A.lilacinumиA.pulchrum - простыми ижелезистыми. Виды других секций опушены, как и два последних вида, волосками обоих типов. В сек. Oligosperma два вида - A.adenophorum и A.krascheninnikovii - имеют наибольшее число волосков - 130 на 1 мм². A.albidum, A.brevibracteatum, A.aculeatum обладают сравнительно редкими волосками - 100 на мм². У остальных видов их

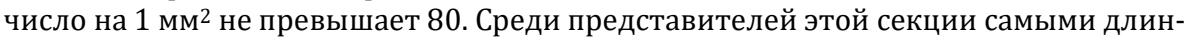
ными волосками(130-192 мкм) выделяются A.albidum и A.krascheninnikovii, сравнительно длинными (152-163 мкм) - A.adenophorum. A.aculeatum, A.pulchrum, A.brevibracteatum и A.lilacinum. У других видов их длина находится в пределах 112114 мкм. Здесь следует отметить, что A.albidum, A.aculeatum и A.brevibracteatum рассматриваемые рядом исследователей [3] синонимами вида A.pungens, а также

${ }^{1}$ E.Yu. Ruzmatov, Associate Professor, Faculty of Natural Sciences, Andijan State University, Uzbekistan.

${ }^{2}$ D. Tuyzieva, Associate Professor, Faculty of Natural Sciences, Andijan State University, Uzbekistan.

${ }^{3}$ B. Nizomova, Lecturer, Faculty of Natural Sciences, Andijan State University, Uzbekistan.

${ }^{4} O$. Yuldasheva, student, Andijan State University, Uzbekistan. 
A.stenostegium - вида A.krascheninnikovii, заметно различаются между собой основными показателями строения прицветничков. Например, у A.aculeatum достигает 110 мкм. A.stenostegium отличается от A.krascheninnikovii меньшим, чем у послед-

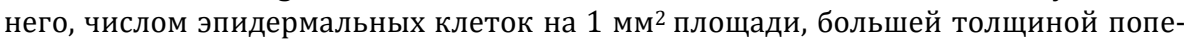
речнего сечения прицветничков, почти в два раза меньшим числом простых волос-

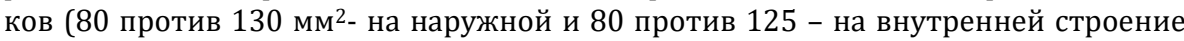
прицветничка). Все это говорит в пользу мнения А.И. Веденского [4] о самостоятельности данных видов.

Виды из сек. Turbinaria опушены с обеих сторон простыми в смеси со стебельчато-головчатыми и железистыми волосками от средней густоты (60-80 на 1 мм $^{2}$ ) до густого (100-140). Прицветнички сек. Pleiosperma с внутренней стороны опушены густьми (152-180 на мм²) простыми в смеси с редкими (50-60) стебельчато-головчатыми железистыми волосками, с наружной поверхности - такими же

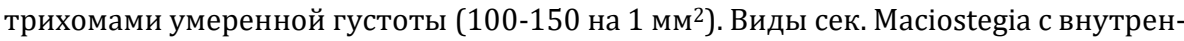
ней стороны опушены умеренно густыми (100 150) простыми и железистыми, с наружной же стороны - густыми (156-200) простыми и умеренно густыми (100140) железистыми волосками. Прицветнички K.popovii опушены сверху простыми

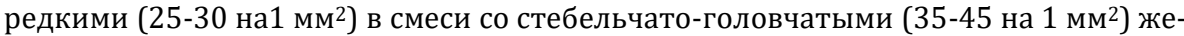
лезистыми волосками. У K.knorringiana они голые, хотя во «Флоре СССР» [5] отмечается опушение их железистыми волосками.

B роде Allochrusa простыми волосками опушены прицветнички у A.paniculata, a y A.gypsophiloides - совершенно голые. Прицветнички рода Drypis лишены каких-либо трихом.

Всем изучаемым таксонам характерна амфистоматность прицветничков, однако устьица отсутствуют на нижней половине внутренней поверхности, соприкасающейся с чашечкой. Устьичный аппарат в основном аномоцитный (устьица окружены четырьмя побочными клетками), реже - диацитный и анизоцитный. Устьица средних размеров - длиной 32-40 мкм и шириной 20-30 мкм - расположены ниже уровня наружной стенки эпидермальных клеток, что характерно для ксерофитов.

В пределах рода Acanthophyllum наибольшим числом устьиц выделяется

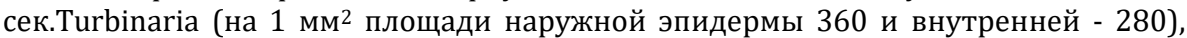
наименьшим (110-189 на мм² на наружной и 100-150 - на внутренней эпидерме) виды сек.Pleiospenna. Виды сек. Macrostegia по этому показателю занимают проме-

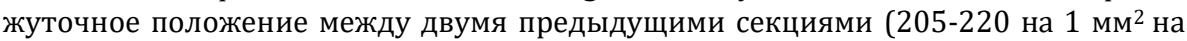
наружной и 140-200 - на внутренней эпидерме). В сек. Oligosperma наименьшим

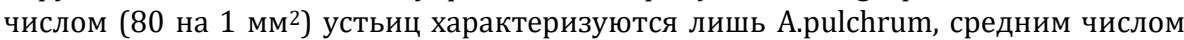
(105-130) -A.lilacinum, A.adenophorum, A.brevibracteatum, A.leiostegium, A.cyrtostegium, наибольшим числом (200) - A.krascheninnikovii. Самые малочисленные усть-

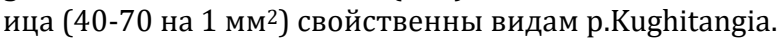

Подвиды и экологические формы монотипного рода Drypis по числу устьиц несколько различаются, особенно большая разница между подвидами и сравнительно небольшая - между экоформами. По размерам и числу эпидермальных клеток прицветнички изучаемых родов относятся в целом к очень крупноклеточным и чрезвычайно крупноклеточным (600-980 на 1 мм² на наружной и 500-898 - на внутренней эпидерме) за исключением сек. Turbinaria, прицветнички которого

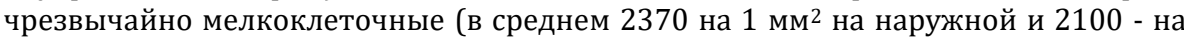
внутренней эпидерме), что ставит ее в обособленное положение в роде Acanthophyllum. 
Следует отметить, что наиболее крупноклеточная эпидерма характерна для нижней части внутренней поверхности прицветничков (400-680 на 1мм²) у представителей Acanthophyllum эта зона образует трубку и поэтому соприкасается, то есть прижимается к чашечке и не имеет устьиц, в то время как у родов Allochrusa и Drypis прицветнички сразу отгибаются наружу и не образуют трубки.

Таким образом, представители рода Acanthophyllum заметно различаются между собой по признакам анатомо-морфологического строения прицветника и, следовательно, ни один из признаков ее строения не может характеризовать род Acanthophyllum в целом.

\section{References:}

[1] Дариев A.C. Морфологическое изучение рода Gossypium и близких ему родов в связи их с систематикой и эволюцией:Автореферат диссертации докт.биол.наук. - Ленинград, 1980 г., - 39 стр.

[2] Napp-Zinn., Eble M. Beitrage zur systematischen Anatomie der Asteraceae. Anthemidae die Trichome.//Plant syst.Evol., 1980, P.169-207.

[3] Бондаренко О.Н. Acanthophyllum C.A.М. - колючелистник //Определитель растений Средней Азии. Т.2, Ташкент, Фан, 1971 г., с.294.

[4] Веденский А.И. Acanthophyllum C.A.M. Acanthophyllum C.A.М.// Флора Узбекистана. Т.2. Ташкент: Из-во АН УзССР,1953 г., с.409-415.4.

[5] «Флора СССР» Т.6., 1936 г., С.780-801. 


\title{
IMPACT OF ANTHROPOGENIC FACTORS ON THE DIVERSITY OF TUSHETI PRO- TECTED AREAS ECOSYSTEMS
}

\author{
Tea Mchedluri ${ }^{1}$ \\ Lado Kakhoidze ${ }^{2}$ \\ Tinatin Khokhobashvili ${ }^{3}$ \\ Asmati Vepkhvadze 4
}

\section{Abstract}

The ecosystems of Tusheti protected areas are negatively affected by anthropogenic factors. Unsustainable forest and pasture management causes the soil erosion, degradation, desertification and biodiversity loss which results into the reduced soil fertility. The study, conducted by us, aimed to determine the fertility level of the arable land in the villages Dartlo and Shenako. We studied the mechanical properties of the soils there, $\mathrm{pH}$ level, mobile nutrients, level of mineral fertilizers. According to the research findings, the upper layers of the soil in village Shenako, are strongly loamy while the lower layers are mildly loamy. The soil in village Dartlo is characterized as strongly and slightly loamy. The soils with such mechanical properties can be successfully used for agricultural purposes. High level of phosphorus and low level of potassium in the soils of village Dartlo is caused due to the input of improperly stored humus and manure which are completely washed away of nitrogen and potassium. As for the phosphorus, it is washed away in smaller quantities from the improperly stored compost and manure and their intensive input increases the level of mobile phosphorus in Dartlo soils. Based on the findings, the soils of Dartlo and Shenako have good arable farmland values.

Key words: Tusheti Protected Areas, Mineral fertilizers Plant, $\mathrm{pH}$.

doi: http://doi.org/10.15350/F_7/42

Research findings and their discussion. Tusheti mountain ecosystems also suffer from degradation due to anthropogenic factors. Excessive grazing occurs, replacing autochthonous plant species with non-autochthonous and soil erosion caused by technogenic causes. As a result, the biodiversity of Tusheti ecosystems is reduced. Desertification is increasing and the fertile soil layers are reduced due to erosive events.

The object of our research was the pastures in two villages of Shenako and Dartlo, in Tusheti, former arable lands and their surrounding lands. We have studied floristic diversity in these areas. We described which species are common in arable and non-arable areas. We determined how fertile the soil is for cultivating vegetable crops in the arable lands of Shenako and Dartlo. (The latter are the places that have not been used in the past for various reasons, most notably, because of their unavailability to plow these plots); Results of soil mechanical analysis, soil $\mathrm{pH}$, soil nutrients, mineral fertilizer content, etc. Field

\footnotetext{
${ }^{1}$ Tea Mchedluri, Doctor of Biological Sciences, Professor, Telavi State University, Georgia.Telavi State University, Georgia.

${ }^{2}$ Lado Kakhoidze, PhD (Ecology), Telavi State University, Georgia.

${ }^{3}$ Tinatin Khokhobashvili, Jumber Lezhava Multi Profile International Academy of Sciences. Georgia.

${ }^{4}$ Asmati Vepkhvadze, PhD (Biology), Telavi State University, Georgia.
} 
studies have shown signs of natural erosion characteristic for the region. Artificially caused erosion is also noted on the slope. This area is significantly damaged by cattle grazing. The erosion process here is accelerated by the influence of anthropogenic factors.

The effects and signs of erosion caused by the overgrazing are also noticeable on the slope of the mountain northwest of Shenako. About 40-60\% of the upper layer of soil has already been removed by slope erosion and the visible thickness of the fertile soil layer is only $40 \mathrm{~cm}$. Although erosion caused by overgrazing in these areas is a serious problem, it is often used as a pasture for cattle.

The traditional method of land use based on vertical zoning is largely forgotten today. The area of cultivated land has decreased and traditional grains are no longer grown on such a large scale. The share of cultivated land is very small and mainly produces potatoes, vegetables and hay. The plots that were previously cultivated can be visualized by the terraced places that are still visible on the landscape today.

The results of soil mechanical analysis, the content of nutrients in the soil and the content of mineral fertilizers in the soil are given in Tables 1-4.

Table 1

\begin{tabular}{|c|c|c|c|c|c|c|c|c|c|}
\hline \multirow{2}{*}{ № } & \multicolumn{9}{|c|}{$\begin{array}{l}\text { Results of soil mechanical analysis. } \\
\text { Fraction size mm. } \%\end{array}$} \\
\hline & Location & $\begin{array}{l}\text { Depth } \\
\text { (sm) }\end{array}$ & $\begin{array}{c}1- \\
0,25\end{array}$ & $\begin{array}{c}0,25- \\
0,05\end{array}$ & $\begin{array}{c}0,05- \\
0,01\end{array}$ & $\begin{array}{c}0,01- \\
0,05\end{array}$ & $\begin{array}{c}0,005- \\
0,001\end{array}$ & $<0,001$ & $<0,01$ \\
\hline 1 & Shenako & $\begin{array}{c}0-20 \\
20-40\end{array}$ & $\begin{array}{l}19 \\
18\end{array}$ & $\begin{array}{l}16 \\
15\end{array}$ & $\begin{array}{l}17 \\
27\end{array}$ & $\begin{array}{l}15 \\
20\end{array}$ & $\begin{array}{c}19 \\
1\end{array}$ & $\begin{array}{l}14 \\
16\end{array}$ & $\begin{array}{l}46 \\
37\end{array}$ \\
\hline 2 & Dartlo & $\begin{array}{c}0-20 \\
20-40\end{array}$ & $\begin{array}{l}36 \\
15\end{array}$ & $\begin{array}{l}25 \\
21\end{array}$ & $\begin{array}{c}13 \\
9\end{array}$ & $\begin{array}{c}6 \\
15\end{array}$ & $\begin{array}{c}9 \\
18\end{array}$ & $\begin{array}{c}7 \\
16\end{array}$ & $\begin{array}{l}21 \\
49\end{array}$ \\
\hline
\end{tabular}

Table 2

\begin{tabular}{|c|c|c|c|c|c|c|c|}
\hline \multirow{2}{*}{ № } & \multirow{2}{*}{ Location } & \multirow{2}{*}{$\begin{array}{c}\text { Depth } \\
(\mathrm{sm})\end{array}$} & $\mathrm{pH}$ & $\begin{array}{c}\text { Organic } \\
\text { Chemical } \\
\text { \% }\end{array}$ & & \multicolumn{3}{|c|}{$\begin{array}{c}\text { Nutritional elements } \\
\text { Rolling forms in soil mg / kg }\end{array}$} \\
\cline { 6 - 8 } & & & $\begin{array}{c}\text { Moving } \\
\text { nitrogen }\end{array}$ & $\begin{array}{c}\text { Moving } \\
\text { Phosphorus }\end{array}$ & $\begin{array}{c}\text { Exchange } \\
\text { Potassium }\end{array}$ \\
\hline 1 & Shenako & $0-20$ & 6,96 & 4,81 & 37,73 & 00.00 & 99,78 \\
& & $20-40$ & 6,42 & 3,98 & 33,69 & 00.00 & 69,85 \\
\hline 2 & Dartlo & $0-20$ & 7,40 & 13,26 & 48,85 & 180,26 & 51,74 \\
& & $20-40$ & 6,87 & 9,25 & 51,21 & 141,85 & 143,05 \\
\hline
\end{tabular}

Table 3

\begin{tabular}{|c|c|c|c|c|c|}
\hline \multirow{2}{*}{ № } & \multirow{2}{*}{ Location } & \multirow{2}{*}{$\begin{array}{c}\text { Manure t/hec. Before } \\
\text { plowing }\end{array}$} & \multicolumn{3}{|c|}{ Nutrient norms kg / ha } \\
\cline { 3 - 5 } & & & \multicolumn{3}{|c|}{ Mineral fertilizer } \\
\cline { 4 - 6 } & Shenako & 40 & 110 & 125 & P205 \\
\hline 1 & Dartlo & 40 & 100 & 0 & 90 \\
\hline 2 & & &
\end{tabular}

Table 4

\begin{tabular}{|c|c|c|c|c|}
\hline \multirow{2}{*}{ № } & Location & \multicolumn{3}{|c|}{ Mineral fertilizers kg / ha. Before plowing } \\
\cline { 3 - 5 } & & Superphosphate & & Potassium chloride \\
\cline { 3 - 5 } & & simple & Triple & \\
\hline 1 & Shenako & 685 & 288 & 169 \\
\hline 2 & Dartlo & - & - & 151 \\
\hline
\end{tabular}


The results of the study showed that the response of $0-20 \mathrm{~cm}$ layer of soil in the villages of Shenako is neutral, $20-40 \mathrm{~cm}$ layer is weakly acidic. The content of organic matter in both layers of the village Shenako is average. It is very high in Dartlo soil. The mobile nitrogen content is very low in both layers of the village Shenako. Even in the soil of Dartlo village.

The mobile phosphorus content in the soil of Shenako village is so low that it cannot be reached at all in the measuring range of the device, but so high in the soil of Dartlo village. Therefore, no phosphorus fertilizers are required under any culture on the Dartlo village lands. Exchange potassium content in the soil of Shenako village is low. It is very low in Dartlo soil top layer. In the lower layer there is an average quantity. In Dartlo soil, the high content of phosphorus and the low content of nitrogen and potassium should be due to the improperly stored manure from which nitrogen and potassium are almost entirely washed. Phosphorus is extracted in very small quantities from the manure, that is why its systematic deposition greatly increases the content of mobile phosphorus in the Dartlo soil.

The results of the study show that the upper layer of soil studied in Shenako village is heavy loamy with mechanical composition, the lower layer is medium loamy. Dartlo soil is light and heavy clayey. Soils of such mechanical composition can be successfully used to grow all vegetable crops. Although cattle grazing is a major traditional activity for Tusheti, it also poses a significant threat to the landscape, habitats and biodiversity. Consequently, degradation and erosion of grazing lands have become an important issue in Tusheti's protected landscape (according to the locals, it is also one of the major problems in Tusheti).

We were conducting research to determine floristic diversity in Dartlo and Shenako areas. To allow for a more accurate accounting, sampling was performed at two sites (in the village). ( 2 ex-arable and 2 unprocessed). One square meter was taken as a square for taking a sample. This square measurement corresponds to the habitat types common to the study area and the task set for the study.

To determine how accurately the floristic diversity of the study area was reflected in the taken sample, additional experiments were performed. Specifically, species diversity on a randomly selected plot was compared to the number of individuals represented on these plots. In this case the size of the square was $1 \mathrm{~m} 2$. This sampling was carried out in habitats on different sites. Species diversity in the study area was predicted based on the size of the sample.

The former arable meadow, located about 200 meters from the village Shenako, was plowed and barley was planted about 55 years ago. Currently it used for grazing. Area - 969 m2 (51 X 19 m); Coordinates: N 42.372530, E 45.666670; Abs. Height - 1881 m; Exposure-SE; Slope inclination-400; Grass-to-flower-max. $35 \mathrm{~cm}$, min. $10 \mathrm{~cm}$; Leaf - Max. $10 \mathrm{~cm}$, min. $2 \mathrm{~cm}$; The main part of the grass is $2-3 \mathrm{~cm}$ long

Plant Species: Cereals- Agrostis capillaris, Festuca caucasica; leguminous plantsCoronilla orientalis, Lotus caucasicus, Trifolium pratense, Trifolium arvense, Trifolium repens, Medicago lupulina; Grasses- Achillea millefolium, Cirsium ketzkhovelii, Carlina vulgaris, Euphorbia squamosa, Erigeron caucasicus,Erigeron uniflorus, Erigeron canadensis, Fragaria viridis, Fragaria vesca, Gnaphalium supinum, Gentiana gelida ,Hieracium pillosella, Hieracium hoppeanum, Hypericum polygonifolium, Hieracium verruculatum, Lamium album, Sedum involucratum, Sideritis comosa, Saxifraga tridactylites, Scabiosa columbaria, Stachys anua,Salvia verticillata, Plantago saxatilis, Plantago caucasica, Potentilla crantzii, Potentilla recta, Potentilla ruprechtii, Polygala alpicola, Verbascum thapsus, Verbascum gossypinum, Medicago lupulina. 
Plots № 1.1, № 1.2

Projection Coverage:

\begin{tabular}{|c|c|c|c|c|c|c|c|c|c|}
\hline $\begin{array}{c}\text { Plot } \\
\text { № }\end{array}$ & $\begin{array}{c}\text { Green mass } \\
\text { (\%) }\end{array}$ & $\begin{array}{c}\text { de- } \\
\text { tri- } \\
\text { tus } \\
\text { (\%) }\end{array}$ & $\begin{array}{c}\text { soil } \\
\mathbf{( \% )}\end{array}$ & $\begin{array}{c}\text { rock } \\
\mathbf{( \% )}\end{array}$ & $\begin{array}{c}\text { Plot } \\
\text { № }\end{array}$ & $\begin{array}{c}\text { Green mass } \\
\text { (\%) }\end{array}$ & $\begin{array}{c}\text { detritus } \\
\text { (\%) }\end{array}$ & $\begin{array}{c}\text { soil } \\
\text { (\%) }\end{array}$ & $\begin{array}{c}\text { rock } \\
\text { (\%) }\end{array}$ \\
\hline 1.1 & 50 & 3 & 2 & 45 & 1.2 & 30 & 15 & 50 & 5 \\
\hline 1.1 & 32 & 30 & 3 & 35 & 1.2 & 30 & 15 & 15 & 40 \\
\hline 1.1 & 40 & 15 & 20 & 25 & 1.2 & 40 & 15 & 40 & 5 \\
\hline 1.1 & 35 & 10 & 40 & 15 & 1.2 & 5 & 5 & 50 & 40 \\
\hline 1.1 & 30 & 5 & 50 & 15 & 1.2 & 30 & 15 & 40 & 15 \\
\hline 1.1 & 70 & 5 & 5 & 20 & 1.2 & 20 & 10 & 40 & 30 \\
\hline 1.1 & 40 & 10 & 40 & 10 & 1.2 & 40 & 5 & 35 & 20 \\
\hline 1.1 & 35 & 15 & 25 & 25 & 1.2 & 15 & 5 & 20 & 60 \\
\hline 1.1 & 50 & 15 & 20 & 15 & 1.2 & 40 & 40 & 15 & 5 \\
\hline 1.1 & 20 & 60 & 5 & 15 & 1.2 & 45 & 35 & 10 & 10 \\
\hline
\end{tabular}

A natural (unprocessed) meadow next to the former arable meadow, 200m away from the village has never been cultivated. It is used for grazing. Area-1140 m2 $60 \mathrm{X} 19$ m2); Coordinates - N 42.372050, E 45.666470; Abs. Height - 1881 m; Exposure -SE; Slope inclination-500; Grass-to-flower-max. $35 \mathrm{~cm}$, min. $8 \mathrm{~cm}$; Leaf - Max. $10 \mathrm{~cm}$, min. $2 \mathrm{~cm}$; The main part of the grass is $2 \mathrm{~cm}$ long

Plant species: Cereals - Agrostis capillaris, Koeleria macranthae; leguminous plants - Trifolium campestre, Trifolium repens; Grasses - Achillea millefolium, Cirsium ketzkhovelii, Campanula petrophila, Consolida orientalis, Camelina sylvestris, Dianthus discolor, Dianthus cretaceus, Erigeron caucasicus, Fragaria vesca, Gnaphalium supinum, Hieracium pillosella, Hieracium polygonifolium, Lamium album, Saxifraga tridactylites, Silene marcowiczii, Stachys anua, Plantago saxatilis, Plantago caucasica, Veronica caucasica,Verbascum thapsus, Verbascum gossypinum, Thymus caucasicus, Tripleurospermus caucasicum, Bupleum polyphyllum.

Former arable meadow, located about 700 meters from the village Dartlo, which was plowed about 55 years ago and rye was sown. Currently it is used for grazing. Area725 m2 (29 X 25 m2); Coordinates -N 42.431330, E 45.594620; Abs. Height - 1924 m; Exposure - SW; Slope inclination -200; Grass height - to flower - $\max .80 \mathrm{~cm}$, $\min .2-3 \mathrm{~cm}$; Leaf - max. $30 \mathrm{~cm}$, min. 1-2 cm; The main part of the grass is in layers of $3-4 \mathrm{~cm}$.

Plots № 2.1, № 2.2

Projection Coverage

\begin{tabular}{|c|c|c|c|c|c|c|c|c|c|}
\hline $\begin{array}{c}\text { Plot } \\
\text { No }\end{array}$ & $\begin{array}{c}\text { Green } \\
\text { mass } \\
\mathbf{( \% )}\end{array}$ & $\begin{array}{c}\text { detritus } \\
\mathbf{( \% )}\end{array}$ & $\begin{array}{c}\text { soil } \\
\mathbf{( \% )}\end{array}$ & $\begin{array}{c}\text { rock } \\
\mathbf{( \% )}\end{array}$ & $\begin{array}{c}\text { Plot } \\
\text { No }\end{array}$ & $\begin{array}{c}\text { Green } \\
\text { mass } \\
\mathbf{( \% )}\end{array}$ & $\begin{array}{c}\text { detri- } \\
\text { tus } \\
\mathbf{( \% )}\end{array}$ & $\begin{array}{c}\text { soil } \\
\mathbf{( \% )}\end{array}$ & $\begin{array}{c}\text { rock } \\
\mathbf{( \% )}\end{array}$ \\
\hline 2.1 & 90 & 10 & 0 & 0 & 2.2 & 20 & 15 & 50 & 15 \\
\hline 2.1 & 80 & 20 & 0 & 0 & 2.2 & 15 & 7 & 65 & 13 \\
\hline 2.1 & 90 & 10 & 0 & 0 & 2.2 & 15 & 20 & 50 & 15 \\
\hline 2.1 & 85 & 15 & 0 & 0 & 2.2 & 15 & 10 & 70 & 5 \\
\hline 2.1 & 70 & 30 & 0 & 0 & 2.2 & 37 & 10 & 50 & 3 \\
\hline 2.1 & 80 & 20 & 0 & 0 & 2.2 & 40 & 7 & 50 & 3 \\
\hline 2.1 & 85 & 10 & 0 & 5 & 2.2 & 50 & 5 & 40 & 5 \\
\hline 2.1 & 80 & 15 & 0 & 5 & 2.2 & 35 & 10 & 50 & 5 \\
\hline 2.1 & 75 & 25 & 0 & 5 & 2.2 & 15 & 15 & 60 & 10 \\
\hline 2.1 & 85 & 10 & 0 & 5 & 2.2 & 15 & 10 & 65 & 10 \\
\hline
\end{tabular}


Plant Species: Cereals - Agrostis capillaris, Phleum alpine; leguminous plants Coronilla orientalis, Lotus caucasicus, Trifolium pratense, Trifolium arvense, Trifolium campestre, Trifolium repens, Medicago lupulina; ; Grasses - Alchimilla caucasica, Alchimilla divaricans, Achillea millefolium, Cirsium pugnax, Campanula petrophila, Cardamine hirsuta, Erigeron uniflorus, Euphrasia caucasica, Gnaphalium caucasicum, Hieracium hypeuryum, Hieracium pillosella, Hieracium hoppeanum, Sibbaldia parviflora, Stachys anua, Plantago lanceolata, Potentilla ruprechtii, Prunella vulgaris, Veronica filiformis, Verbascum thapsus, Taraxacum confusum

A natural (unprocessed) meadow next to a former arable meadow, $700 \mathrm{~m}$ away from the village has never been cultivated due to unavailability and is used as pasture. Area - 750 m2 (25 X 30 m); Coordinates -N 42.431080, E 45.545000; Abs. Height - 1930 m; Exposure-W; Slope inclination -45 0; Grass-to-flower-max. $30 \mathrm{~cm}$, min. $2 \mathrm{~cm}$; Leaf Max. $25 \mathrm{~cm}$, min. $1 \mathrm{~cm}$; The main part of the grass is $1-2 \mathrm{~cm}$ long.

Plant Species: Cereals - Nardus stricta; leguminous plants - Trifolium arvense,Trifolium campestre; Grasses - Alchimilla divaricans,Anthemis dumetorum, Cirsium ketzkhovelii, Camelina sylvestris,Dianthus cretaceus, Erigeron canadensis, Gnaphalium caucasicum,Coronilla varia,Hieracium hypeuryum, Hieracium pillosella, Hypericum polygonifolium, Sedum involucratum, Scabiosa columbaria, Plantago lanceolata,Plantago saxatilis, Potentilla ruprechtii, Prunella vulgaris, Veronica caucasica, Veronica serpyllifolia, Verbascum thapsus, Verbascum gossypinum, Thymus caucasicus Most of the problems were identified in areas previously allocated for agricultural activities and later converted to pasture. The natural regeneration processes in the area were greatly affected by continuous grazing, which significantly impeded habitat restoration and enhanced erosion processes. Grazing has both direct and indirect effects on habitats, wildlife and spatial distribution of species (some species have to be moved higher than sea level to avoid disturbance). Sometimes local shepherds take their cattle for grazing in places where it is forbidden; The main reason for this may be that the boundaries of protected areas are not clearly marked everywhere. Some shepherds prefer their cattle to graze in or near the village than on traditional pastures on the higher mountain slopes. This adversely affects the quality of life (both locals and visitors), increases the risk of habitat degradation (increased eutrophication, replacement of natural plant species with nitrophilic species), changes the water regime and increases the risk of erosion in such areas. The problem of eutrophication is observed around sheep holds, which are located in unsafe areas.

Unsustainable use of pastures and forests in Tusheti causes erosion, degradation, desertification and loss of biodiversity. Tusheti mountain ecosystems also suffer from degradation due to anthropogenic factors. Excessive grazing occurs, replacing autochthonous plant species with non-autochthonous and soil erosion caused by technogenic causes. As a result, the biodiversity of Tusheti ecosystems is reduced. Desertification is increasing and the fertile soil layers are reduced due to erosive events.

\section{Conclusion:}

1. The results of the study show that the upper layer of soil studied in Shenako village is heavy loamy, mechanically loamy, and lower medium loamy. Dartlo soil is light and heavy clayey. Soils of such mechanical composition can be successfully used to growing all kinds of vegetable crops.

2. In Dartlo soil, the high content of phosphorus and the low content of nitrogen and potassium should be due to the improperly stored manure. From which, almost entirely, is washed nitrogen and potassium. Phosphorus is extracted in very small quantities from the manure, that is why its systematic deposition greatly increases the content of mobile phosphorus in Dartlo soil. 
3. The unsustainable use of pastures and forests in Tusheti Protected Areas causes erosion, degradation, desertification and loss of biodiversity. Tusheti ecosystems are undergoing degradation due to anthropogenic factors. Excessive grazing occurs, replacing autochthonous plant species with non-autochthonous and soil erosion caused by technogenic causes. As a result, the biodiversity of Tusheti ecosystems is reduced. Desertification is increasing and the fertile soil layers are reduced due to erosive events.

4. During the study of the Tusheti villages - Shenako and Dartlo, most of the problems were identified in areas previously allocated for agricultural activities and later converted into pasture. Natural regeneration processes in the area was affected by continuous grazing, which significantly impeded habitat restoration and enhanced erosion processes.

5. Although cattle grazing is a major traditional activity for Tusheti, it also poses a significant threat to the landscape, habitats and biodiversity. Consequently, degradation of grazing areas and erosion have become an important issue in Tusheti's protected landscape.

\section{References:}

[1] Bochoridze, G. (1993) Tusheti. Tb: Science, p.510

[2] Tusheti Protected Areas Management Plan, 2014

[3] Ketskhoveli, N. (1959) Vegetation of Georgia. Georgian SSR Academy of Sciences, Tbilisi.

[4] Makalatia, S. (1983) Tusheti. Tb: Stream, p.229

[5] Makashvili, A. Botanical Dictionary (Plant Names). TB: "Soviet Georgia", p.260

[6] Kvachakidze, R. (1996) Geobotanical Areas of Georgia: Science, p.128

[7] Kvachakidze, R. (2010) Geobotanical Areas of Georgia. Tbilisi: p.176

[8] Conklin, A.R., \& Meinzholt, R. 2004. Field Sampling: Principles and Practices in Environmental Analysis. ISBN: 0824754719. Marcel Dekker, Ink. New York \& Basel.

[9] Elzinga, C.L., Salzer, D.W., Willoughbi, J.W., Gibbs, G.P. 2001. Monitoring Plant and Animal Populations. ISBN: 063204442X. Blackwell Science, Inc. 


\title{
DETERMINATION OF THE CONTENT OF HEAVY METALS IN PARTICLES OF POLLEN OF PLANTS CAUSING POLLINOSIS
}

\section{Zuroshvili Lamara ${ }^{1}$}

\begin{abstract}
The content of trace elements in the pollen particles of some plants growing in the Vake Park in Tbilisi was studied. It was found that the content of trace elements $(\mathrm{Mn}, \mathrm{Cu}, \mathrm{Zn})$ has been increasing over recent years. The change in their content depends on the habitat of the place where the plants grow.
\end{abstract}

Key words: pollen, metals, hay fever, allergy, plant.

doi: http://doi.org/10.15350/F_7/43

В высокоразвитых странах катастрофически растет количество разнообразных аллергических заболеваний. Этому способствует прямые и косвенные причины Загрязнение среды обитания принимает все более обширный масштаб. В больших городах воздух загрязнен выхлопными газами автомобилей, что вызывает процесс воспаления органов дыхания и свободное вторжение аллергенов в организм. Полиноз - pollen т. е. частицы пыльцы- наиболее распространенное явление среди аллергических заболеваний Она характерно для людей особо восприимчевых к раздражителям растительного происхождения, как пыльца растений

Следует отметить что пыльца растений содержится в воздухе в определенном количестве даже не во время массированного цветения. Со временем происходит осаждение (т. е. “дождь пыльцы”) не только в открытых местах, но и во внутренних помещениях и вызывает аллергические заболевания.

Доказано, что для полинозов характерны региональные особенности, вызванные климатическими и географическими факторами в частности распространение тех или иных видов пыльцы и ареалов их распространения.

Английский доктор Бlackley заметил, что симптомы заболевания проявлялись во время цветения растений и выдвинул предположение, что пыльца, содержащаяся в большом количестве в воздухе, попадает в дыхательные пути и вызывает чихание и насморк. Изучение химического содержания пыльцы показала, что ее составе 5,3\% воды и 94, 7\% сухого вещества. Ставится вопрос-какая часть пыльцы является аллергеном-белки, углеводы или пигменты.

В Грузии ввиду климатических и географических особенностей, изучение полиноза имеет особенное значение. В Грузии находятся пустыни, полупустыни, горные луга и равнины, что создают условия для разнообразного растительного покрова. Следовательно в Грузии встречаются почти все известные до сих пор аллергены.

В результате аэрополинологического исследования в Грузии выявлены три основных периода цветения растений и связанных с этим три периода зараждения полиноза: ранняя весна, весна-лето и лето-осень. В зоне Тбилиси в этом периоде основной причиной полиноза чинара и осина. Пыльца в большом количестве содержит сахара, липиды, белковые соединения, минеральные соли, витамины, K, Na, $\mathrm{Ca}, \mathrm{Mg}, \mathrm{Cu}, \mathrm{Fe}, \mathrm{p}$, пигменты и множество ферментов в т. ч. каталазу, амилазу, проте-

\footnotetext{
${ }^{1}$ Zuroshvili Lamar, Doctor of Biology, Iakob Gogebashvili Telavi State University, Georgia.
} 
азу, липазу ,нуклеазу, карбоксилазу. В большом количестве встречаются аминокислоты пепсин, трипсин и др. Установлено, что чем больше содержится аминокислоты, тем более активны аллергены. Пчелы стремятся к цветам, содержащих минимальное количество аминокислот в пыльцах. Окончательно не установлено сколько соединений вызывает реакцию аллергии в организме, однако считается, что аллергены в пыльце имеют комплексную природу: белки, углеводы или белки пигменты.

Аллергическим воздействием обладает живая пыльца, она попадает на слизистую поверхность, пропитывается ею и носители аллергенов пыльцы вторгаются в кровь и лимфу и производят сенсибилизацию организма.

Целью нашего исследования было определение в пыльцах растений, вызывающих полиноз, содержание тяжелых металлов и установление частоты появления полиноза на примере г. Тбилиси.

Определение содержания тяжелых металлов производится методом атомно-абсорбционной сректрофотометрии в частицах пыльцы, собранных в разные годы, с голосемянных и скрытосемянных растений.

Частицы пыльцы высушиваем при комнатной температуре, перед анализом помещали на 4 часа в сушильный шкаф до $60 \%$ влажности, затем измельчали в фарфоровой ступке и посевали через 1мл сито. По 2 г. сжигали в муфельных печах, золу растворяли соляной кислотой в ванне с разогревом 05 часа (раствор в соотношении 1: 10) В растворе определяли медь 324,7 на анализной линии цинк 213, 9 мг, марганец 279, 5 мг. Для атомизации применяется ацетилен или пропан-бутил.

Опиты показали, что содержание тяжелых металлов увеличивается в течение последних лет. Это нарастание связано с ухудшением экологической среды вокруг произрастаемых растений.

Таблица 1

Содержание биоэлементов частицах пыльцы кедров произрастающих в парке

"ВАКЕ" г. Тбилиси в 2015-2018 гг.

\begin{tabular}{|c|c|c|c|c|}
\hline \multirow{3}{*}{ элемент } & \multicolumn{2}{|c|}{ голосемянные } & \multicolumn{2}{|c|}{ скрытносемянные } \\
\hline & кедр & кедр & ясень & ясень \\
\hline & 2015 г. & 2018 г. & 2015 г. & 2018 г. \\
\hline $\mathrm{Mn}$ & $30,5 \mathrm{M} г / к г$ & $50,8 \mathrm{M} / \mathrm{к} \Gamma$ & $35,5 \mathrm{Mг} / к г$ & 60,3 мг/кг \\
\hline $\mathrm{Cu}$ & 12 мг/ кг & 15,5мг/кг & 20мг/ кг & 64,3 мг/кг \\
\hline $\mathrm{Zn}$ & 55,5мг/кг & 75 мг/кг & 70мг / кг & 350 мг/ кг \\
\hline
\end{tabular}

Было изучено содержание микроэлементов в частицах пыльцы некоторых растений, произрастающих в парке” Ваке" г. Тбилиси.

Было установлено что содержание микроэлементов (Mn, $\mathrm{Cu}, \mathrm{Zn})$ возрастает на протяжении последних лет.

Изменение их содержания зависит от среды обитания места, где произрастают растения.

\section{References:}

[1] М. Гордезиани, Г. Квеситадзе -Основы химической экологии, Тбилиси 2000.

[2] Л. Зурошвили, Р. Манагадзе, Д. Зурошвили. Природные катастрофы, Тбилиси 2020.

[3] Маренюк Г.В. Загрязнение окружающей среды и здоровые населения, Кишинев,1984.

[4] Climate change futures. Health, Ecologikal and Ekonomik Dimensions, September 2006.

[5] Health and Climate Change, Launched in London, Nov 25, 2009. 


\title{
CONTENT OF ENVIRONMENTAL EDUCATION OF STUDENTS
}

\author{
Tosheva Dildora ${ }^{1}$ \\ Kholikulov Mukhammad ${ }^{2}$
}

\begin{abstract}
This article provides information about environmental safety and the content of environmental education for students.
\end{abstract}

Key words: ecological sense, ecological perception, ecological imagination, ecological consciousness, ecological knowledge, information, skills, habits, ecological culture.

doi: http://doi.org/10.15350/F_7/44

Ekologik xavfsizlik muammosi nafaqat milliy va mintaqaviy, balki butun insoniyatning umumbashariy muammosidir. Ekologiya hozirgi zamonning keng miqyosdagi keskin ijtimoiy muammolaridan biridir. Uni hal etish barcha xalqlarning manfaatlariga mos bo'lib, rivojlanishning hozirgi kuni va kelajagi ko'p jihatdan ana shu muammoning hal qilinishiga bog'liqdir.

Atoqli pedagog V.A.Suxomlinskiy «Bolalarga jonim fido» asarida «Men bolalar «Alifbo»sini ochib, birinchi so'zni hijjalab o'qishlariga qadar avval dunyodagi eng ajoyib kitob - tabiat kitobini mutolaa etishlarini istardim» - deb ta'kidlaganidek, bu borada barcha ishlarni bolaning kichikligidanoq boshlash maqsadga muvofiqdir. O'zbekiston Respublika «Kadrlar tayyorlash milliy dasturi»da: «Ta'limning barcha darajalarida ta'lim oluvchilarning ekologik va sanitariya-gigiena ta'limi hamda tarbiyasini takomillashtirish zarur» - deb alohida ta'kidlangan.

O'zbekiston Respublikasi Konstitusiyasining 50-moddasida: «Fuqarolar atrof-muhitga ehtiyotkorona munosabatda bo'lishga majburdirlar» va 55-moddasida esa: «Yer va er osti boyliklari, suv, o'simlik va hayvonot dunyosi hamda boshqa tabiiy zahiralar umumiy boyliklardir. Ulardan oqilona foydalanish zarur va ular davlat mudofaasidadir» deb juda o'rinli ta'kidlangan. Fuqarolarda ekologik madaniyatni tarkib toptirish, ularga tabiat, atrof-muhit bilan qanday munosabatda bo'lishni o'rgatish ijtimoiy pedagogika nazariyasi va amaliyotining eng dolzarb mavzusiga aylandi.

O'zbekiston Respublikasining 1992 yil 9 dekabrda qabul qilingan «Tabiatni muhofaza qilish to'g'risida»gi Qonuni, «Sog'lom avlod uchun» ordenining ta'sis etilishi, shu nomda Davlat dasturi, «Ekologik ta'lim-tarbiya konsepsiyasi» ning ishlab chiqilishi, «Ekosan» jamg'armasining tuzilishi va 2000 yilning «Sog'lom avlod yili» va 2005 yilning «Sihat-salomatlik yili» deb e'lon qilinib, davlat dasturi ishlab chiqilishi ekologik tarbiyaning ijtimoiy muammolarini hal qilishga qaratilganligidan dalolat beradi.

Aholi sonining tez o'sib borishi natijasida ekologik ijtimoiy muammolar ham tobora ortib bormoqda. Ayniqsa, aholini yer, suv, energetika, oziq-ovqat bilan ta'minlash haqidagi muammolar butun dunyo ijtimoiy muammolariga aylanib bormoqda. Yer kurrasida insonning farovon yashashi endi ekologik muammolarni yechishga bog'liq bo'lib qolmoqda. Ekologik muammolarning ilmiy, iqtisodiy, texnik, gigienik, yuridik, estetik, pedagogik va psixologik yo'nalishlari mavjud. Pedagogik yo'nalishda ekologik ta'lim va tarbiya berish ko'zda tutiladi. Ekologik ta'lim deganda, aholiga berilishi lozim bo'lgan tabiat bilan inson orasidagi munosabatlarni ifodalovchi bilimlar tizimi tushuniladi. Ekologik tarbiya esa insonning atrof-muhitga nisbatan munosabatini tarbiyalashdir. Ekologik ta'lim-tarbiyadan bosh maqsad ham turli yoshdagi kishilarda atrof-muhit va uning muammolariga ongli munosabatni shakllantirishdan iborat.

\footnotetext{
${ }^{1}$ Tosheva Dildora, Bukhara State University, Uzbekistan.

${ }^{2}$ Kholikulov Mukhammad, Bukhara State University, Uzbekistan.
} 
Boshlang'ich sinf o'quvchilarida ekologik savodxonlik va madaniyat ta'lim-tarbiya muassasalari va oilada amalga oshiriladi. Boshlang'ich sinf o'quvchilariga ekologik tarbiya berishda milliy xususiyat va tomonlarga asosiy e'tiborni qaratish lozim. Bular: suv, yer, tuproq, havo muqaddas hisoblangan. Ota-bobolarimiz: «Suv - tabiat in'omi, hayot manbai», - deb bejiz aytishmagan.

Maktabda o'quvchilarni ekologik tarbiyalashda bunday ma'lumotlarni berib borish o'qituvchilarning asosiy vazifasi bo'lmog'i darkor.

Atrof-muhitga, tabiat boyliklariga e'tiborsiz bo'lish butun sayyoraga jiddiy zarar yetkazishi ma'lum. Inson bilan tabiat o'rtasidagi muammolarni yechish zaruriyati tug'ildi. O'quvchilarda ekologik madaniyatni shakllantirish, tabiat, atrof-muhit bilan qanday munosabatda bo'lishni o'rgatish pedagogika nazariyasi va amaliyotida dolzarb muammoga aylandi. Ayniqsa, umumta'lim maktablarida maktab partasidanoq tabiatga muhabbat ruhida tarbiya berishga astoydil kirishish zarur.

Ta'lim muassasalarida ekologik tarbiya berish mazmuni quyidagilarni o'z ichiga oladi:

-atrof-muhit va uning shaxs ma'naviy dunyosiga ta'siri;

-tabiat va uning ahamiyatini anglash;

-tabiatga muhabbatni shakllantirishda maktab va oilaning hamkorligi;

-o'z tumani, shaharini, qishloq va maktab hovlisini ko'kalamzorlashtirishda, hatto sinf xonasidagi o'simliklarni ham parvarishlashga qiziqtirish;

-oiladagi, maktabdagi tabiatni, o'simliklar va hayvonot dunyosini e'zozlashga o'rgatish, jonivor va qushlarni parvarish qilish;

-yoshlarni ekologik tarbiyalashda milliy an'ana va udumlarni qayta tiklash, ularga e'tiborni kuchaytirish.

«Avesto»da kishilarni ekologik tarbiyalash bo'yicha quyidagi tadbirlar belgilangan: "Inson butun umri davomida suv, tuproq, olov, umuman dunyodagi jamiki yaxshi narsalarni pok va bus-butun asrashga burchlidir. Yer, suv, havo, olovni asrash qoidalarini buzgan kishi 400 qamchi urish jazosiga mahkumdir. Ota-bobolarimiz azalazaldan tabiatga yuksak mehr ko'rsatishgan. Yurtni obod etishgan, ko'chalarni, hovlilarni sarishta qilishgan." Bundan ko'rinadiki, azaldan tabiatga munosabat milliy qadriyatlarimiz bilan uyg'unlashib ketgan.

Maktab o'quvchilari ekologik tarbiya jarayonida quyidagilarni bilishlari zarur:

-tabiat haqida tushuncha, tabiiy muhit, tabiiy omillar va ular orasidagi bog'lanish;

-tabiat boyliklaridan tejab-tergab foydalanish va ularni muhofaza qilish;

-atrof-muhitni ifloslantirishdan saqlash;

-tabiatni kelajak avlodlar uchun tabiiy holda qoldirishga intilish.

Umuman, maktab o'quvchilarining ekologik ta'lim-tarbiyasi quyidagi tuzilish va tizimda olib borilsa, uning samaradorligi ta'minlanadi: ekologik his-tuyg'u, ekologik idrok, ekologik tasavvur, ekologik tushuncha, ekologik bilim, ma'lumot, ko'nikma, malaka, odat, ekologik madaniyat (mahorat) va hokazo.

Tabiatni muhofaza qilish hozirgi zamonning asosiy masalalaridan biri bo'lib qolganligi o'quvchi ongiga singdiriladi. Haqiqatdan ham, tabiiy boyliklardan haddan tashqari ko'p darajada foydalanish, yangi yerlarni rejasiz o'zlashtirish oqibatida, ekologik muvozanat keskin o'zgardi, atrof-muhit ifloslandi. Ekologik tarbiyada insonning atrof-muhitga nisbatan munosabatlari tarbiyalanib, o'quvchilar ongiga yoshligidan singdirib boriladi. Ekologik ta'lim-tarbiya maktabda barcha fanlarni o'qitishda amalga oshirilishi ko'zda tutiladi. Ekologik ta'lim-tarbiyadan bosh maqsad ham yosh avlodda atrof-muhit va uning muammolariga ongli munosabatni shakllantirishdan iboratdir.

\section{Foydalanilgan adabiyotlar:}

[1] O'zbekiston Respublikasi Kadrlar tayyorlash Milliy dasturi. 3.3.1- va 3.3.2- bandlar. // 0'zbekiston Respublikasi Oliy Majlisining Axborotnomasi. 1997 y., 11- 12-son, 295-modda. 
For notes 


\section{B\&M Publishing}

Scientific researches for development future. Conference Proceedings. B\&M Publishing, March 28, 2020, New York, USA. 134 pp.

PQN 100

ISBN 978-1-941655-00-9 